WATER-RESOURCES DATA

FOR NORTH FORK BENS CREEK, SOMERSET COUNTY, PENNSYLVANIA, AUGUST 1983 THROUGH SEPTEMBER 1988

By Emitt C. Witt III

U.S. GEOLOGICAL SURVEY

Open-File Report 89-584

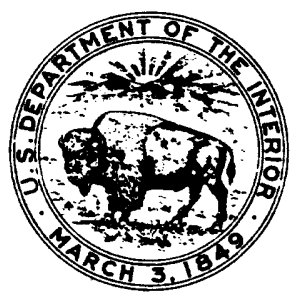

Lemoyne, Pennsylvania

1991 


\section{U.S. DEPARTMENT OF THE INTERIOR}

MANUEL LUJAN, JR., Secretary

U.S. GEOLOGICAL SURVEY

Dallas L. Peck, Director

For additional information write to:

District Chief

U.S. Geological Survey, WRD

840 Market Street

Lemoyne, Pennsylvania 17043-1586
Copies of this report can be purchased from:

U.S. Geological Survey

Books and Open-File Reports Section Federal Center

Box 25425

Denver, Colorado 80225 


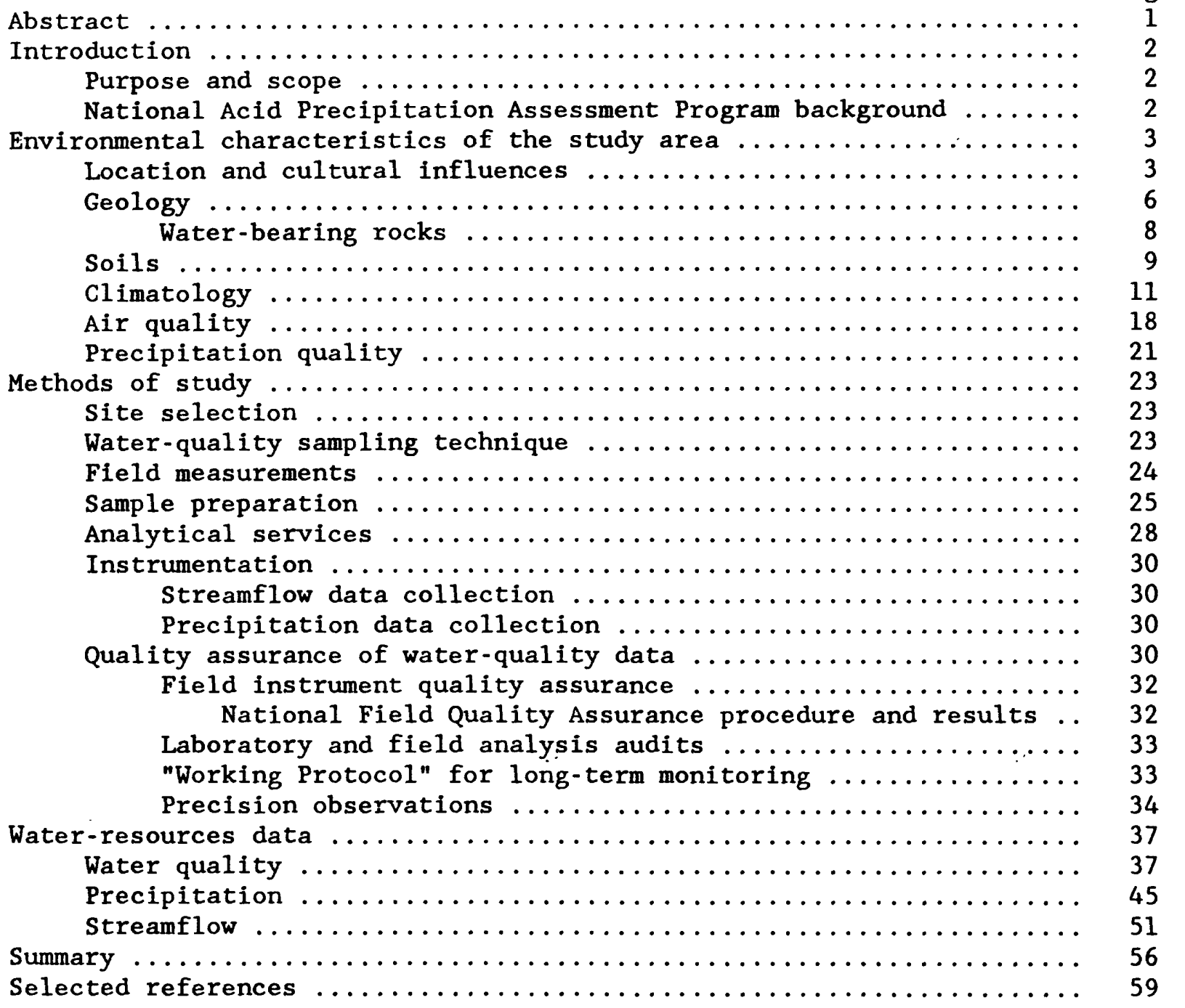




\section{ILLUSTRATIONS}

Figures 1-2.--Maps showing:

1.--Location of study basin and precipitation

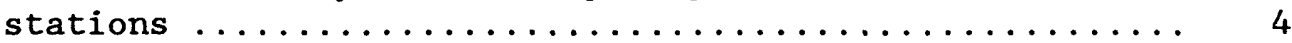

2. - Topography of North Fork Bens Creek basin .......... 5

3.--Geologic section through Laurel Hill at North Fork Bens Creek .................... 6

4.--Distribution of major soil series in the North Fork Bens Creek basin ........................ 10

5-8.--Graphs showing:

5. - Average monthly maximum and minimum temperature for Stoystown, Pennsylvania, 1961-83............

6.--Average monthly snowfall accumulation on ground at Boswell, Pennsylvania, 1960-83 ............. 15

7.--Average daily "Engineering Corrected Solar Radiation" for southwestern Pennsylvania ............... 16

8.--Average monthly pan evaporation for water years

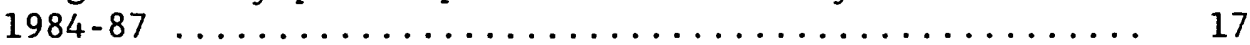

9.--Densities of sulfur oxides and nitrogen oxides emissions for counties in western Pennsylvania ...... 20

10.--pH of wet deposition (annual volume-weighted average) in the United States ........................ 22

11-13.--Sample preparation technique:

11. - August 1983 through September $1983 \ldots \ldots \ldots \ldots \ldots \ldots \ldots$

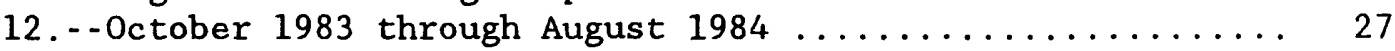

13. - - September 1984 through September $1988 \ldots \ldots \ldots \ldots \ldots \ldots . \ldots 28$

14-16. --Graphs showing:

14. - Median and range of streamflow measurements made when water-quality samples were collected

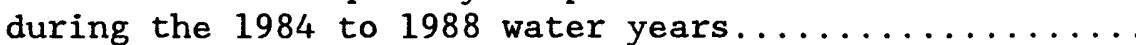

15. - Annual median and range of concentration for major water-quality constituents for samples collected during 1984-88 for North Fork Bens Creek....

16. - - Comparison of average monthly precipitation with observed monthly precipitation for

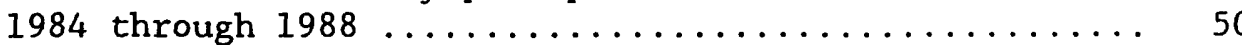

17. - -Hydrographs of daily discharge for North Fork

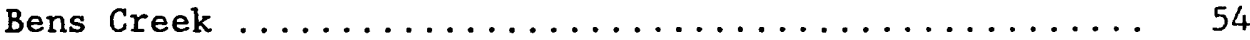

18. - - Monthly stream flow for 1985 and $1988 \ldots \ldots \ldots \ldots \ldots \ldots \ldots 5$

19.--Flow-duration curve for North Fork Bens Creek ......... 55 
Table 1.--Physical and chemical properties of each soil series

in the North Fork Bens Creek basin ............. 9

2-6. --Monthly temperature statistics at Stoystown, Pennsylvania for:

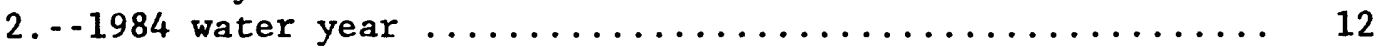

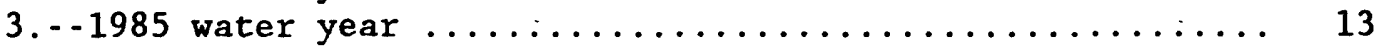

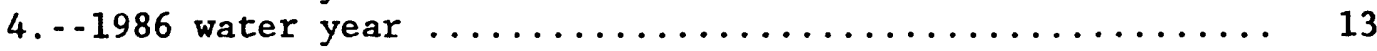

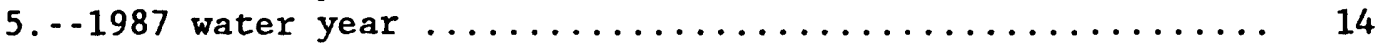

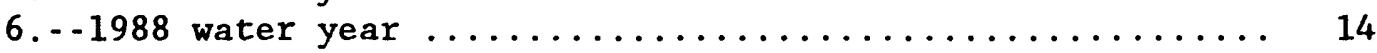

7. - - Chemical constituents analyzed from each sample split ... 26

8. - - Split volumes and preservation criteria ............ 26

9.--Laboratory analytical methods and reporting levels

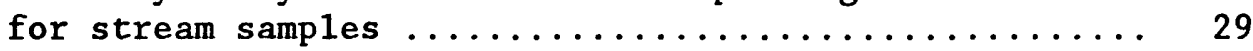

10. - Quality-assurance methods used during the project...... 31

11. - -Results of precision for 11 replicate analyses,

March 1986 through September $1988 \ldots \ldots \ldots \ldots \ldots \ldots \ldots . \ldots . \ldots 36$

12. - Results of container blanks for dissolved constituents

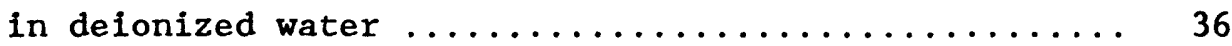

13. - Results of filtration blanks for dissolved constituents in deionized water ..................... 37

14-18. - Water chemistry data for North Fork Bens Creek from:

14.--August 1983 through September $1984 \ldots \ldots \ldots \ldots \ldots \ldots \ldots$........ 40

15. - October 1984 through September $1985 \ldots \ldots \ldots \ldots \ldots \ldots \ldots . \ldots 1$

16.--October 1985 through September $1986 \ldots \ldots \ldots \ldots \ldots \ldots \ldots . \ldots \ldots 2$

17.--October 1986 through September $1987 \ldots \ldots \ldots \ldots \ldots \ldots \ldots 43$

18.--October 1987 through September $1988 \ldots \ldots \ldots \ldots \ldots \ldots \ldots . \ldots 4$

19. - Total daily precipitation for North Fork Bens Creek

from October 1983 through September $1988 \ldots \ldots \ldots \ldots 46$

20-21. - Daily mean discharge data for North Fork Bens Creek from:

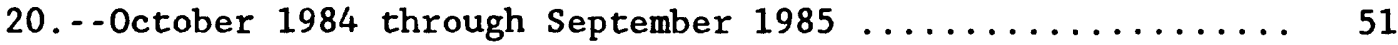

21.--October 1987 through September $1988 \ldots \ldots \ldots \ldots \ldots \ldots \ldots . \ldots 2$ 


\section{CONVERSION FACTORS AND ABBREVIATIONS}

For the convenience of readers who prefer metric (International System) units rather than the inch-pound units in this report, the following conversion factors may be used:

Multiply inch-pound units

inch (in.)

foot $(f t)$

mile (mi)

acre

square mile $\left(\mathrm{mi}^{2}\right)$
By Length

$$
\begin{aligned}
& 25.4 \\
& 0.3048 \\
& 1.069
\end{aligned}
$$

Area

$$
\begin{gathered}
0.4047 \\
259.0
\end{gathered}
$$

\section{Flow}

\section{foot per second ( $\mathrm{ft} / \mathrm{s}$ )}

cubic foot per second $\left(f t^{3} / s\right)$

cubic foot per second per square mile $\left[\left(\mathrm{ft}^{3} / \mathrm{s}\right) / \mathrm{mi}^{2}\right]$

gallon per minute (gal/min)

ton, short

degree Fahrenheit $\left({ }^{\circ} \mathrm{F}\right)$
0.3048

0.02832

0.01093

0.06308

\section{$\underline{\text { Mass }}$}

0.9072

Temperature

$5 / 9 \times\left({ }^{\circ} \mathrm{F}-32\right)$
To obtain metric units

millimeter (mm)

meter (m)

kilometer $(\mathrm{km})$

hectare (ha)

hectare (ha) meter per second (m/s)

cubic meter per second $\left(\mathrm{m}^{3} / \mathrm{s}\right)$

cubic meter per second per square kilometer

$\left[\left(\mathrm{m}^{3} / \mathrm{s}\right) / \mathrm{km}^{2}\right]$

liter per second $(\mathrm{L} / \mathrm{s})$

megagram $(\mathrm{Mg})$

degree Celsius $\left({ }^{\circ} \mathrm{C}\right)$

\section{Other Abbreviations}

micrograms per cubic meter $(\mu \mathrm{g} / \mathrm{L})$

microsiemens per centimeter at 25 degrees Celsius $(\mu \mathrm{s} / \mathrm{cm}$ )

microequivalents per liter ( $\mu \mathrm{eq} / \mathrm{L}$ )

milliequivalents per liter (meq/L)

milligrams per liter (mg/L)

Sea Level: In this report, "sea level" refers to the National Geodetic Verticle Datum of 1929 (NGVD of 1929)--a geodetic datum derived from a general adjustment of the first-order level nets of both the United States and Canada, formerly called "Sea Level Datum of 1929." 


\title{
WATER-RESOURCES DATA FOR NORTH FORK BENS CREEK, SOMERSET COUNTY, PENNSLYVANIA, AUGUST 1983 THROUGH SEPTEMBER 1988
}

By Emitt C. Witt III

\begin{abstract}
$B=$ sin and climatological characteristics, quality-assurance data and results, and water-resources data for North Fork Bens Creek, in Somerset County, Pennsylvania, are available from August 1983 through September 1988. The basin is underlain by sedimentary rocks of Mississippian and Pennsylvanian age, and has an anticlinal structure. Soils are predominantly stony silt clays and have $\mathrm{pH}$ values ranging from 3.6 to 5.5. The lowest temperature $\left[-30.0^{\circ} \mathrm{C}\right.$ (degrees Celsius)] was recorded during January 1985, and the highest temperature $\left(36.7^{\circ} \mathrm{C}\right)$ was recorded during July 1988. Snowfall accumulates mostly during January and February. Annual snowfall averages about 69 inches. Average wind speed is highest during winter, about 11 miles per hour. Solar radiation is most intense from late May to early June; typically, solar radiation is highest during the growing season. Pan evaporation averages 0.17 inches per day (in/day) during the growing season and 0.02 in/day during the nongrowing season. Sulfur dioxide and sulfate contaminants in the air have declined since 1977. Nitrogen dioxide and nitrates have remained constant. Emissions of sulfates and nitrates are high in the adjacent western counties; loads of these contaminants in individual counties range from 1,000 to 450,000 tons per year. Average volume-weighted $\mathrm{pH}$ for precipitation in western Pennsylvania is about 4.0. Quality-assurance procedures showed that chemical data collected from August 1983 through February 1986 were satisfactory. Precision values of quality data for March 1986 through September 1988 are marginal to satisfactory. Negative alkalinities were observed during water years 1984, 1986, and 1988. Continuous precipitation data are available from October 1983 through September 1988. Precipitation was typically higher than normal for the 1984, 1985, and 1986 water years. Continuous streamflow data are available for water years 1985 and 1988. Seventy percent of annual flows occur during the nongrowing season. Monthly flow typically is highest in March. The maximum recorded discharge of 92 cubic feet per second was observed on March 31, 1985.
\end{abstract}




\section{INTRODUCTION}

Water-resources data for North Fork Bens Creek were collected from August 1983 through September 1988. These data were collected in response to the Acid Precipitation Act of 1980 and twice reviewed by committees of the National Acid Precipitation Assessment Program (NAPAP) (Hood, 1985; McFayden and Joyner, 1987).

North Fork Bens Creek is one of 16 sites established nationwide for determining long term effects of acid deposition on base-flow stream quality. Initially, support for this work was a cooperative effort by both the U.S.

Geological Survey and the U.S. Environmental Protection Agency (USEPA). Since 1986, support for data collection has come exclusively from the Research Division of the U.S. Geological Survey in Reston, Virginia. Data collection is expected to continue until 1990.

\section{Purpose and Scope}

This report compiles all water-resources data collected for North Fork Bens Creek, provides an evaluation of the accuracy of the data, and provides water-resource scientists with a report specifically formatted to present environmental-data summaries and reference material necessary to calibrate a hydrologic-simulation model and make geochemical interpretations.

The report includes descriptions of the study area, data-collection methods, quality-assurance methods and results, and water-chemistry, precipitation-quantity, and streamflow-quantity data. Environmental characteristics, including geology, soils, and climatology, are discussed in detail. Monthly summary statistics of precipitation are compared with those for a typical year. Distributions of annual water-chemistry data are illustrated by using plots of interquartile ranges. Annual streamflow extremes and hydrographs, monthly flow comparisons, and flow duration are discussed.

\section{National Acid Precipitation Assessment Program Background}

The NAPAP was established by an Interagency Task Force jointly chaired by the USEPA, National Oceanic and Atmospheric Administration (NOAA), Departments of Agriculture, Energy, and Interior, and the Council on Environmental Quality. The goal of NAPAP is to develop and progressively refine an objective and comprehensive body of information on the causes and effects of acidic deposition. The program includes research, monitoring, and assessment activities that emphasize the timely development of a firm scientific basis for decision making by legislators, regulatory officials, resources managers, environmental groups, and the public. The National Program consists of almost 300 agencies in 7 major areas of research (National Atmospheric Precipitation Assessment Program, 1986-88). 


\section{Location and Cultural Influences}

The North Fork Bens Creek basin is on the eastern slope of Laurel Hill about $6 \mathrm{mi}$ (miles) southwest of Johnstown, Pennsylvania (fig. 1). The basin drains $3.45 \mathrm{mi}^{2}$ (square miles) and ranges in elevation from 1,340 to 2,740 $\mathrm{ft}$ (feet) above sea level. North Fork Bens Creek drains into the North Fork Reservoir about $300 \mathrm{ft}$ downstream from the data collection station. The North Fork Reservoir is a potable water supply for the greater Johnstown area. Diversion from the reservoir does not affect the results of data collection. Figure 2 shows the basin boundaries, topography, and major roads.

The North Fork Bens Creek basin is completely forested and cultural influences upstream of the sampling station are minimal. The basin is within the mixed mesophytic forest region of Pennsylvania. The region is dominated by beech-maple-oak hardwoods. Locally, species are diversified because of differences in soil depth, moisture, elevation, and microclimate. The area was logged in the late 1880's and early 1900's, and present forest growth is second- and third-growth timber.

North Fork Bens Creek is listed by the Pennsylvania Fish Commission as a high-quality cold-water fishery. Although not annually stocked with trout, the stream does have a remnant native brook trout population (Sharpe and others, 1987). An abundance of insect larvae and crayfish have been observed in the benthos of North Fork Bens Creek.

A short length of State Route 271 in the northwest part of the basin can potentially contribute contaminants to the system. This cultural impact, however, covers less than 1 percent of the watershed. A study to determine its direct effect on stream quality was not done. 


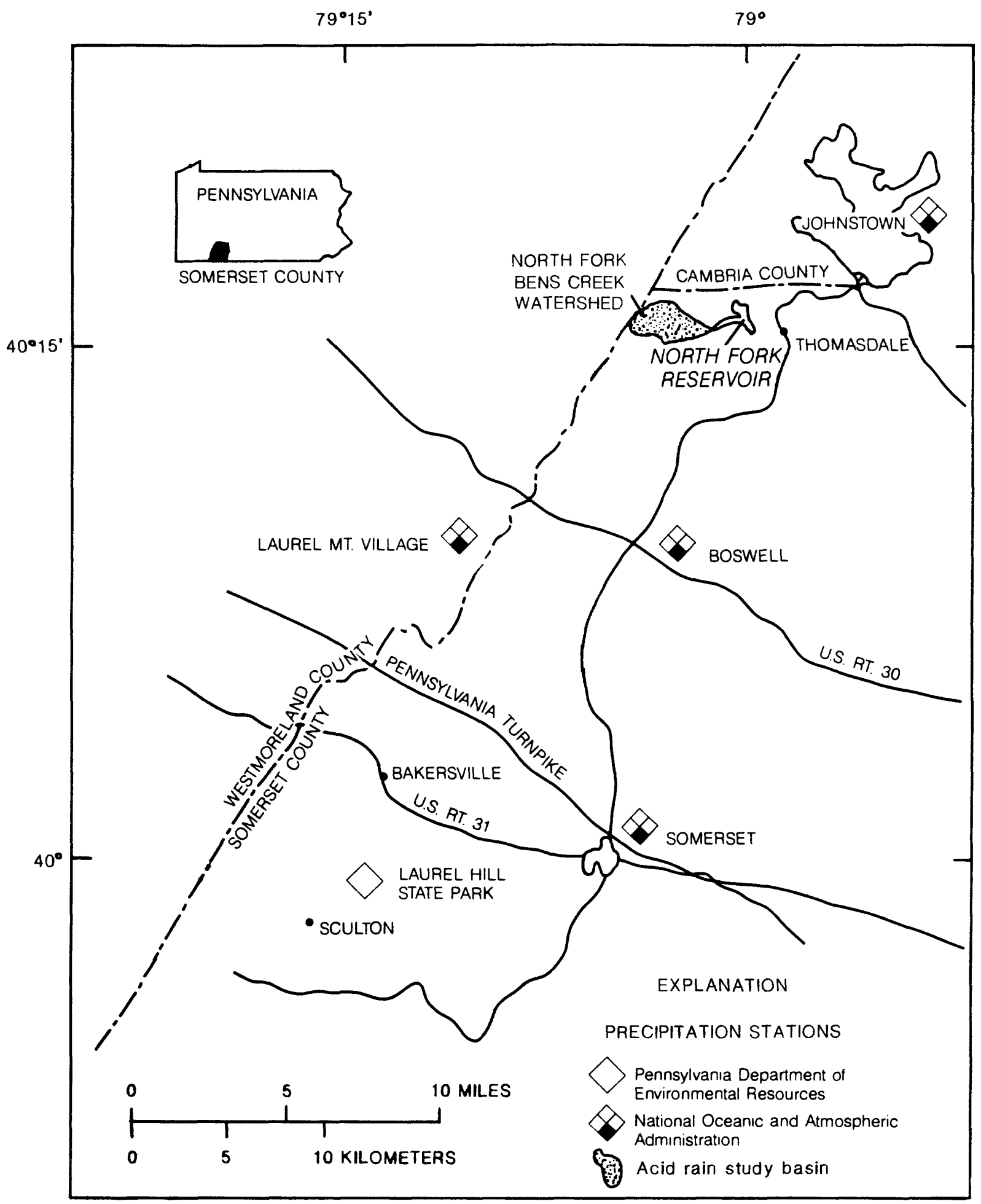

Figure 1.--Location of study basin and precipitation stations. 


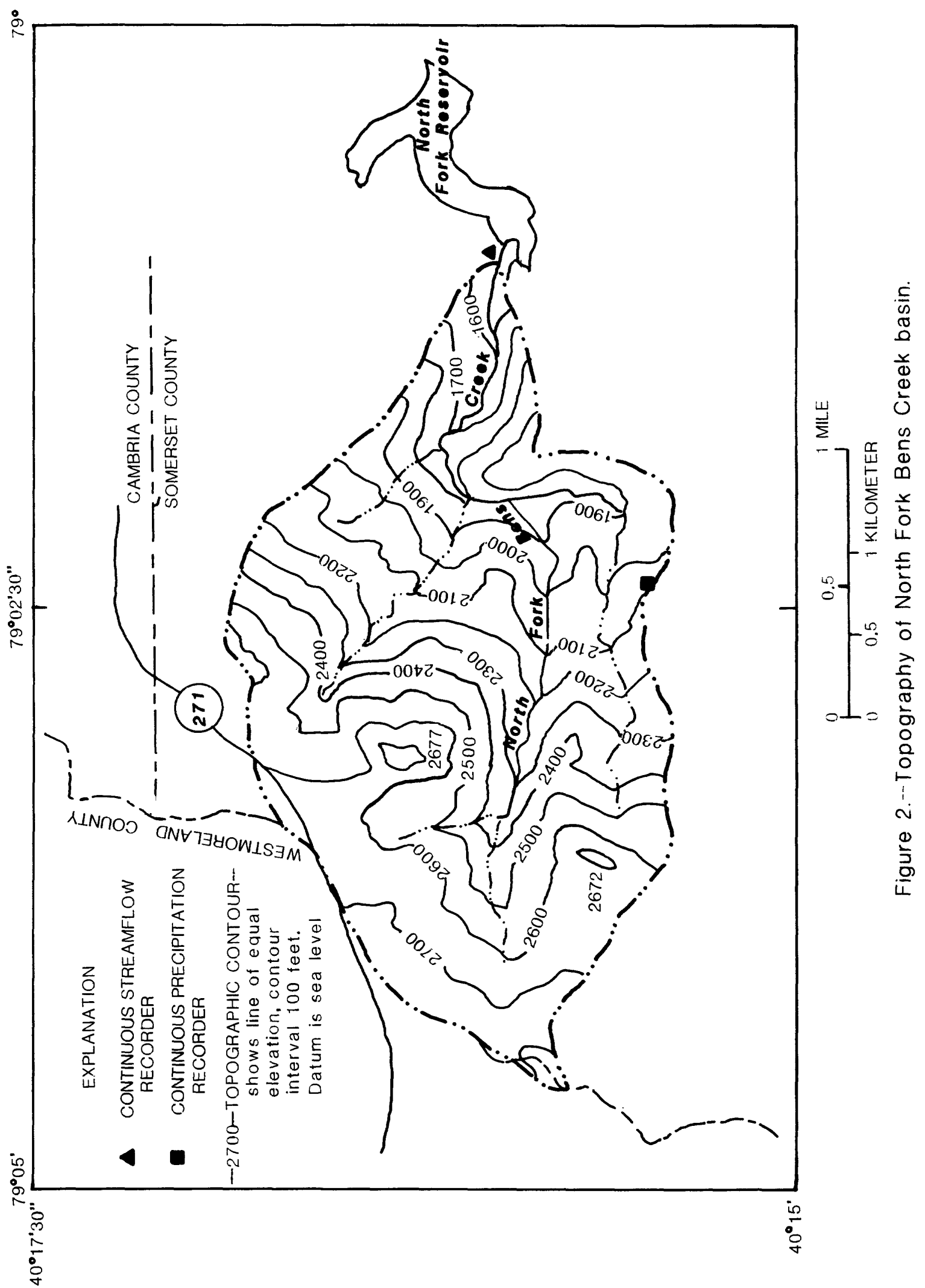




\section{Geology}

The study basin is in the Allegheny Mountains section of the Appalachian Plateau physiographic province. North Fork Bens Creek originates on the eastern slope of Laurel Hill, which is an anticlinal ridge. The axis of the anticline is oriented in a northeast-southwest direction. Average vertical relief from the crest of Laurel Hill anticline to the trough of the Johnstown syncline is $1,500 \mathrm{ft}$. Rock units on the eastern slope of Laurel Hill dip about 5 degrees northwest-southeast. Differential erosion of the dipping rock units has exposed several rock types in the basin (fig. 3). This section of

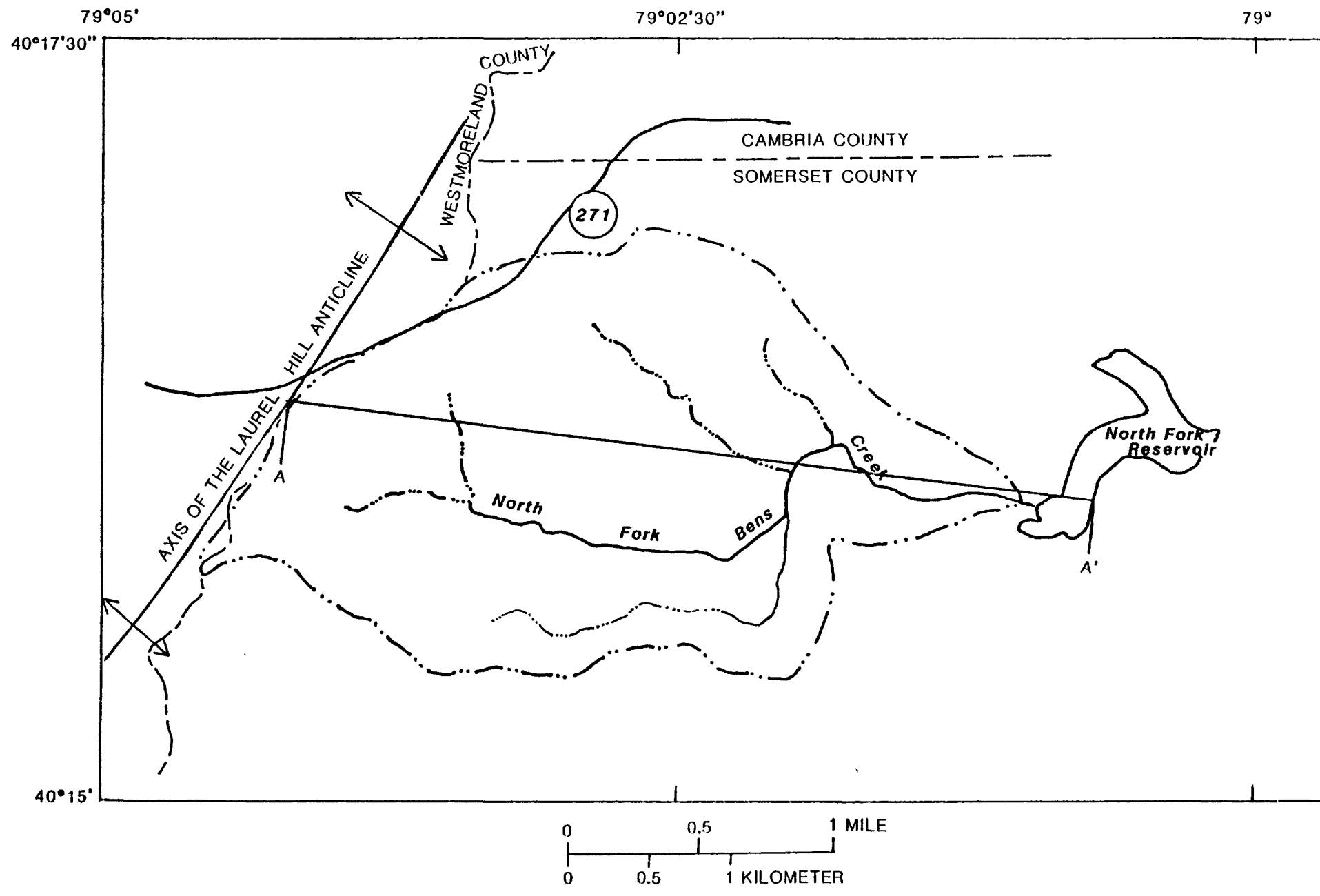


Laurel Hill is underlain by sedimentary rocks of Mississippian and

Pennsylvanian age. The major rock unit exposed in the basin is the Burgoon Sandstone. This resistant sandstone forms ridges along Laurel Hill. The next younger unit, stratigraphically, is the Mauch Chunk Formation. The lithology of the Mauch Chunk Formation is sandstone, shale, and some limestone. Other rock units in the basin are, from older to younger stratigraphically, the Pottsville, Allegheny, and Conemaugh Groups, which, on Laurel Hill, are composed mainly of sandstones and shales (Hickok and Moyer, 1940).

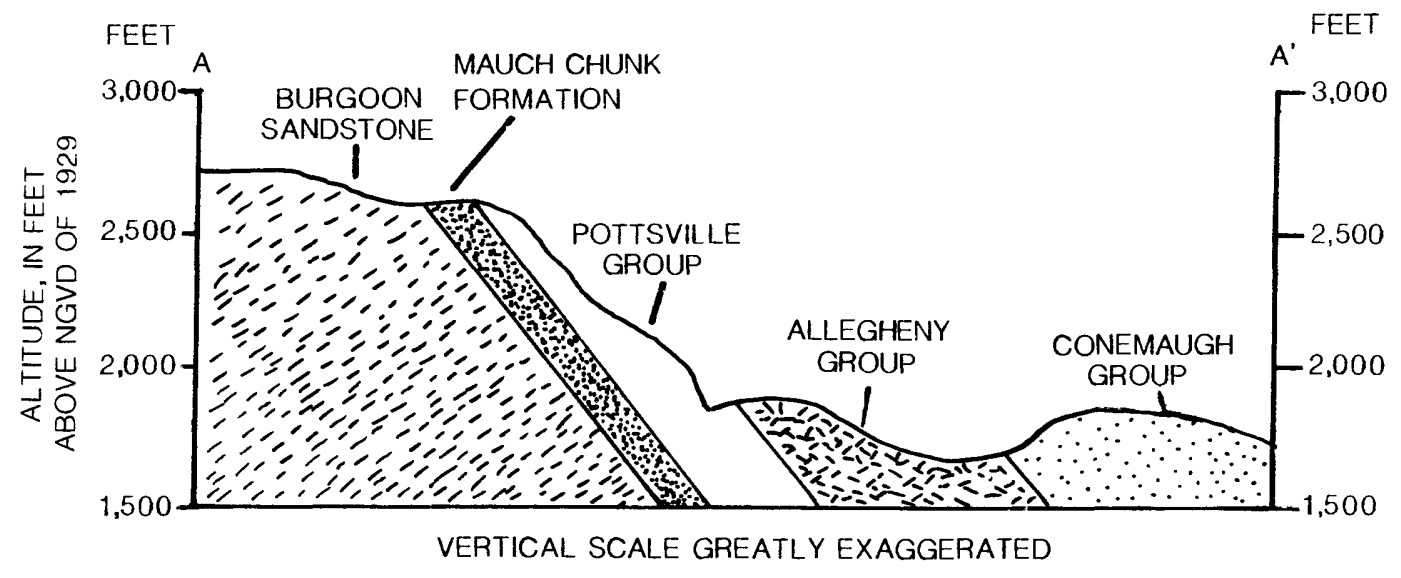

Figure 3.--Geologic section through Laurel Hill at North Fork Bens Creek. 
A description of the possible water bearing rocks in the study area is important for geochemical interpretation as well as hydrologic modeling. Flint (1981) has described the water bearing rocks for southern Somerset County. His discussion includes data and findings by other investigators in the region. These data include well-log information, results of aquifer tests, and predictive-yield statistics for different rock types.

Laurel Hill generally is composed of sandstones, shales, and limestones. Within the North Fork Bens Creek basin, sandstone and shale are dominant. Limestone formations and limestone members of formations are either absent or sparsely distributed near the northern sections of Laurel Hill. On the basis of the Rockwood geologic quadrangle map, limestone is absent in the North Fork Bens Creek basin (Berg and others, 1981).

Sandstones have good porosity and permeability and are considered the best producers of water within the county (Flint, 1981). Sixty-two sandstone wells were sampled by Lohman (1938); reported yields were from 2 to 250 gal/min (gallons per minute). The average yield was determined to be about 46 gal/min. Burgoon salidstone, which is the major ridge-forming rock on Laurel Hill, is reported to have fairly good permeability. Wells in Burgoon sandstone can be expected to yield $50 \mathrm{gal} / \mathrm{min}$. About 29 percent of the North Fork Bens Creek basin is underlain with Burgoon sandstone. Between 3 to 10 percent of the basin is underlain by other conglomeratic sandstones.

Shales in Somerset County have porosity, but pores are small preventing free movement of waters. Shales are excellent absorbers of water but generally do not yield large quantities. Lohman (1938) found that shale wells yielded from less than 1 to $15 \mathrm{gal} / \mathrm{min}$ of water. About $50 \mathrm{gal} / \mathrm{min}$ is the maximum expectable yield. Sandy shale wells have been reported to yield an average of $45 \mathrm{gal} / \mathrm{min}$.

Shale and sandy shale are the most abundant rock types on Laurel Hill and in Somerset County. On Laurel Hill, the Mauch Chunk, Pottsville, and Allegheny Formations are predominantly shale and sandy shale. About 22, 33, and 15 percent of the North Fork Bens Creek basin is underlain by Mauch Chunk, Pottsville, and Allegheny Formation shales, respectively. These shale formations frequently crop out along the stream bank. Shales of the Mauch Chunk Formation are most visible at these outcrops and are a source of surface waters by seepage through fractures between the shale interbeds. 


\section{Soils}

Soils in the study area are predominantly of the Hazelton-Cookport series and the Berks-Weikert series. Hazelton-Cookport soils are classified as deep and well drained to moderately well drained. Berks-Weikert soils are classified as moderately deep to shallow and well drained. Most of these soils are loamy skeletal soils formed in material derived from acidic shales, siltstone, and sandstones (U.S. Department of Agriculture, 1983). Less significant soils found in the basin are Leck Hill, Rayne-Gilpin, Brinkerton, Ernest, and Albright series.

Because soils can have a major influence on stream chemistry during storm events (Barker and Witt III, 1990), the distributions of each series in the watershed are illustrated in figure 4. Table 1 lists the physical and chemical properties for each series shown in figure 4 for depths up to 65 in. (U.S. Department of Agriculture, 1983).

Table 1.--Physical and chemical properties of each soil series in the North Fork Bens Creek basin [in., inch; in/hr, inch per hour; in/in, inch per inch; $\mathrm{K}$, soil erodibility factor; $T$, soil-loss tolerance factor]

\begin{tabular}{|c|c|c|c|c|c|c|c|c|}
\hline Series & $\begin{array}{l}\text { Depth } \\
\text { (in.) }\end{array}$ & $\begin{array}{l}\text { Permeability } \\
\quad(\text { in } / \mathrm{hr})\end{array}$ & $\begin{array}{l}\text { Available } \\
\text { water } \\
\text { capacity } \\
\text { (in/in) }\end{array}$ & $\begin{array}{c}\text { Soil } \\
\text { pH } \\
\text { (units) }\end{array}$ & $\begin{array}{l}\text { Shrink } \\
\text { swell } \\
\text { potential }\end{array}$ & $\begin{array}{l}\text { Eros } \\
\text { fact } \\
\mathrm{K}\end{array}$ & $\frac{\mathrm{s}}{\mathrm{T}}$ & $\begin{array}{c}\text { Organic } \\
\text { composition } \\
\text { (percent) }\end{array}$ \\
\hline Hazelton & $0-36$ & $0.6-2.0$ & $0.08-.15$ & $3.6-5.5$ & Low & 0.24 & 3 & $1.0-3.5$ \\
\hline Cookport & $0-22$ & $.6-2.0$ & $.11-.16$ & $4.5-5.5$ & Low & .28 & 3 & $1.5-3.5$ \\
\hline Ernest & $0-19$ & $.6-2.0$ & $.11-.16$ & $4.5-5.5$ & Moderate & .32 & 3 & $1.0-3.5$ \\
\hline Rayne-Gilpin & $0-47$ & $.6-2.0$ & $.11-.16$ & $4.5-5.5$ & Low & .28 & 4 & $2.5-4.0$ \\
\hline Leck Hill & $0-45$ & $.6-5.0$ & $.16-.20$ & $4.5-7.3$ & Low & .20 & 3 & $2.5-4.0$ \\
\hline Brinkerton & $0-24$ & $.6-2.0$ & $.16-.20$ & $4.5-5.5$ & Moderate & .32 & 3 & $1.5-4.0$ \\
\hline Albright & $0-65$ & $.6-2.0$ & $.16-.20$ & $4.5-5.5$ & Low & .43 & 2 & $2.5-4.0$ \\
\hline
\end{tabular}

1 The ability of the soil to hold water and make it available to plants (U.S. Department of Agriculture, 1983) 


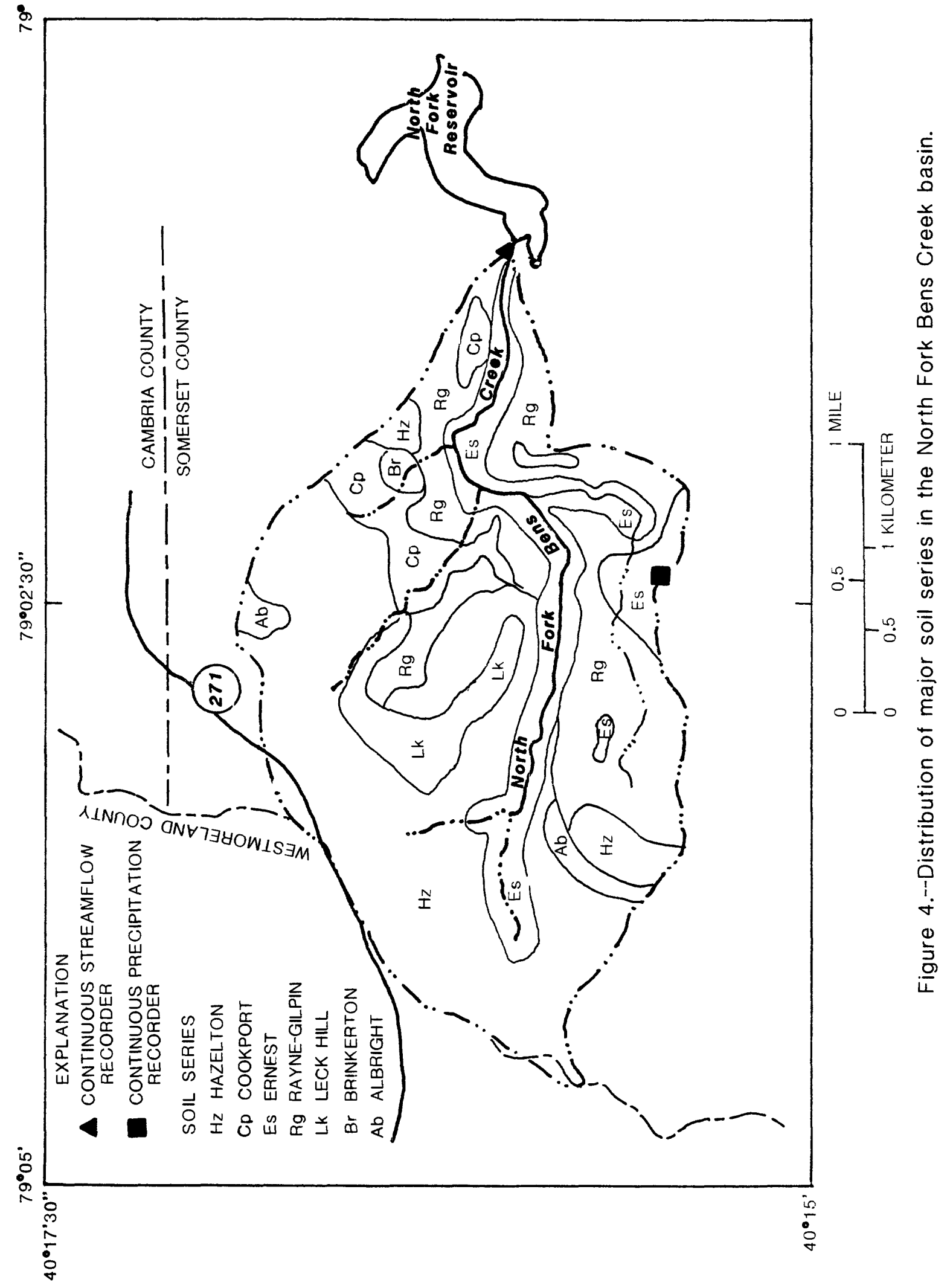




\section{Climatology}

Knowledge of the climatology for the study area is important for developing accurate interpretations of the existing hydrologic data. Geochemical interpretations use climatological data for determining mineral dissolution rates and weathering and erosion of geologic formations. Hydrological models, such as the Hydrologic Simulation Program-Fortran model developed by the USEPA, use time-series data of temperature, wind speed, solar radiation, and pan evaporation for driving algorithms used to simulate snowme1t, overland runoff, and infiltration. The data and summaries in this section are provided to aid the researcher in making accurate interpretations of the observed hydrologic data. The climatological data given are summaries of NOAA observations obtained at representative stations.

Temperature is important for explaining seasonal hydrologic flows and for calibrating surface water simulation models. Snowmelt rates and the reduction in infiltration during the nongrowing season are substantially dependent on temperature. Temperature was not collected at the study site. However, the nearby NOAA climatological station at Stoystown, Pennsylvania, is representative of the study area (fig. 1).

Average monthly maximum and minimum temperatures at Stoystown were calculated from 1961-83 data (fig. 5). Results indicate that November through March represent months where the minimum temperatures are below freezing. January typically is the coldest month with both average maximum and minimum temperatures below freezing. The highest monthly temperatures typically are during July and August.

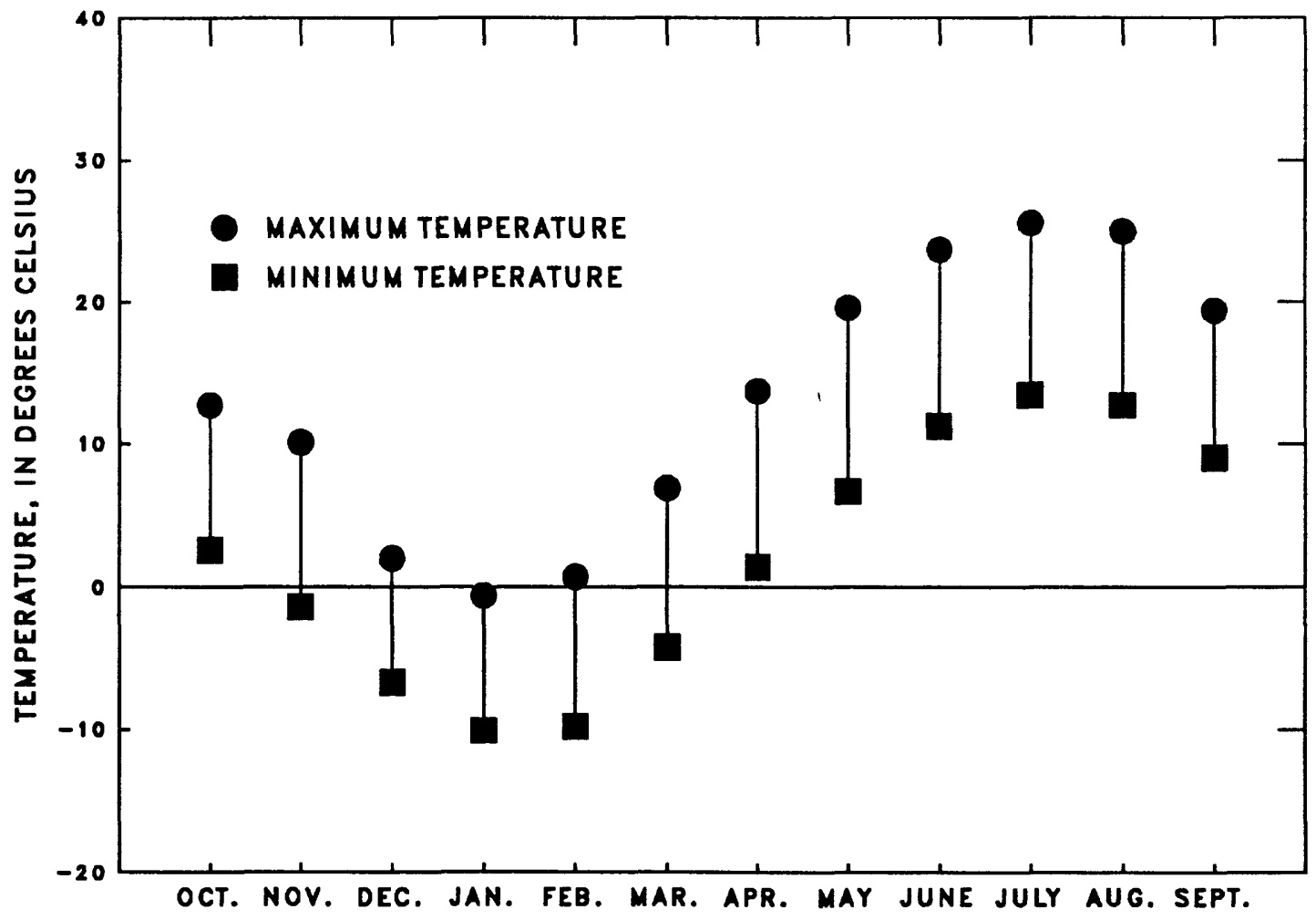

Figure 5.--Average monthly maximum and minimum temperature for Stoystown, Pennsylvania, 1961-83. 
Tables 2-6 are temperature summaries of the Stoystown climatological station during the study period. The coldest months during the study are the same as those shown in figure 5 ; temperatures were below $-17.8^{\circ} \mathrm{C}\left[0^{\circ} \mathrm{F}\right.$ (degrees Fahrenheit)] most often during January and February. The lowest recorded temperature $\left(-30^{\circ} \mathrm{C}\right)$ occurred during January 1985 . Water year 1987 was the coldest year; minimum temperatures for a period of 171 days were below freezing. The average duration below freezing for the nongrowing season is 154 days. Typically hard freezes begin in December and continue until late February or early March. Several freeze/thaw events of shorter duration can occur during March when temperatures have been observed to fall below $-17.8^{\circ} \mathrm{C}$ $\left(0^{\circ} \mathrm{F}\right.$ ) (tables 2 and 4 ). The warmest months during the study also are the same as those shown in figure 5; temperatures occasionally exceeded $32.2^{\circ} \mathrm{C}\left(90^{\circ} \mathrm{F}\right)$ during July and August (tables 5 and 6 ). The highest recorded temperature of $36.7^{\circ} \mathrm{C}\left(98^{\circ} \mathrm{F}\right)$ occurred during July 1988 .

Table 2.--Monthly temperature statistics at Stoystown, Pennsylvania, 1984 water year (adapted from NOAA, 1983-84) [ ${ }^{\circ} \mathrm{C}$, degrees Celsius; ${ }^{\circ} \mathrm{F}$, degrees Fahrenheit]

\begin{tabular}{|c|c|c|c|c|c|c|c|}
\hline Month & $\begin{array}{l}\text { Average } \\
\text { maximum } \\
\left({ }^{\circ} \mathrm{C}\right)\end{array}$ & $\begin{array}{c}\text { Average } \\
\text { minimum } \\
\left({ }^{\circ} \mathrm{C}\right)\end{array}$ & $\frac{\text { Mon }}{\left(_{\left({ }^{\circ} \mathrm{C}\right)}^{\text {Maximum }}\right.}$ & $\frac{\text { Miy }}{\text { Minimum }}$ & $\begin{array}{c}\text { Days } \\
\text { above } \\
32.2^{\circ} \mathrm{C}\left(90^{\circ} \mathrm{F}\right)\end{array}$ & $\begin{array}{c}\text { Days } \\
\text { below } \\
0^{\circ} \mathrm{C}\left(32^{\circ} \mathrm{F}\right)\end{array}$ & $\begin{array}{c}\text { Days } \\
\text { below } \\
-17.8^{\circ} \mathrm{C}\left(0^{\circ} \mathrm{F}\right)\end{array}$ \\
\hline October & 14.7 & 3.3 & 25.0 & -6.7 & 0 & 5 & 0 \\
\hline November & 8.8 & -1.5 & 20.6 & -7.8 & 0 & 22 & 0 \\
\hline December & -1.1 & -10.0 & 12.8 & -25.5 & 0 & 30 & 6 \\
\hline January & -.6 & -11.3 & 11.1 & -26.7 & 0 & 31 & 6 \\
\hline February & 5.9 & -4.2 & 15.6 & -13.3 & 0 & 26 & 0 \\
\hline March & 3.4 & -7.9 & 15.6 & -22.8 & 0 & 31 & 3 \\
\hline April & 13.8 & 1.2 & 27.8 & -6.7 & 0 & 13 & 0 \\
\hline May & 18.1 & 5.8 & 28.9 & -3.3 & 0 & 2 & 0 \\
\hline June & 25.9 & 9.8 & 31.1 & 2.8 & 0 & 0 & 0 \\
\hline July & 25.1 & 9.9 & 29.4 & 1.7 & 0 & 0 & 0 \\
\hline August & 25.9 & 12.9 & 29.4 & 3.9 & 0 & 0 & 0 \\
\hline September & 19.8 & 5.7 & 27.8 & -2.2 & 0 & 6 & 0 \\
\hline
\end{tabular}

${ }_{1} \mathrm{~A}$ water year is the 12 -month period beginning on October 1 and ending on September 30 and designated by the year in which it ends. 
Table 3.--Monthly temperature statistics at Stoystown, Pennsylvania, 1985 water year (adapted from NOAA, 1984-85) [ $\mathrm{C}$, degrees Celsius; ${ }^{\circ} \mathrm{F}$, degrees Fahrenheit]

\begin{tabular}{|c|c|c|c|c|c|c|c|}
\hline Month & $\begin{array}{l}\text { Average } \\
\text { maximum } \\
\left({ }^{\circ} \mathrm{C}\right)\end{array}$ & $\begin{array}{c}\text { Average } \\
\text { minimum } \\
\left({ }^{\circ} \mathrm{C}\right)\end{array}$ & $\frac{\text { Mon }}{\left(^{\circ} \mathrm{C}\right)}$ & 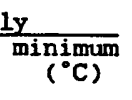 & $\begin{array}{c}\text { Days } \\
\text { above } \\
32.2^{\circ} \mathrm{C}\left(90^{\circ} \mathrm{F}\right)\end{array}$ & $\begin{array}{c}\text { Days } \\
\text { below } \\
0^{\circ} \mathrm{C}\left(32^{\circ} \mathrm{F}\right)\end{array}$ & $\begin{array}{c}\text { Days } \\
\text { below } \\
-17.8^{\circ} \mathrm{C}\left(0^{\circ} \mathrm{F}\right)\end{array}$ \\
\hline October & 18.6 & 5.6 & 26.1 & -0.6 & 0 & 3 & 0 \\
\hline November & 7.6 & -4.0 & 16.7 & -11.1 & 0 & 28 & 0 \\
\hline December & 8.0 & -3.4 & 17.8 & -13.9 & 0 & 26 & 0 \\
\hline January & -2.9 & -11.8 & 19.4 & -30.0 & 0 & 31 & 4 \\
\hline February & 1.9 & -9.5 & 19.4 & -23.9 & 0 & 28 & 3 \\
\hline March & 9.1 & -2.2 & 22.2 & -11.1 & 0 & 26 & 0 \\
\hline April & 17.2 & 3.1 & 28.9 & -12.2 & 0 & 10 & 0 \\
\hline May & 20.8 & 7.6 & 26.7 & -2.8 & 0 & 1 & 0 \\
\hline Juns & 22.5 & 10.5 & 26.7 & 2.8 & 0 & 0 & 0 \\
\hline July & 25.6 & 13.3 & 29.4 & 5.6 & 0 & 0 & 0 \\
\hline August & 24.6 & 12.3 & 30.6 & 4.9 & 0 & 0 & 0 \\
\hline September & 23.3 & 8.9 & 30.6 & -.6 & 0 & 2 & 0 \\
\hline
\end{tabular}

Table 4.--Monthly temperature statistics at Stoystown, Pennsylvania, 1986 water year (adapted from NOAA, 1985-86) [ ${ }^{\circ} \mathrm{C}$, degrees Celsius; ${ }^{\circ} \mathrm{F}$, degrees Fahrenheit]

\begin{tabular}{|c|c|c|c|c|c|c|c|}
\hline \multirow[b]{2}{*}{ Month } & \multirow{2}{*}{$\begin{array}{l}\text { Average } \\
\text { maximum } \\
\left({ }^{\circ} \mathrm{C}\right)\end{array}$} & \multirow{2}{*}{$\begin{array}{c}\text { Average } \\
\text { minimum } \\
\left({ }^{\circ} \mathrm{C}\right)\end{array}$} & \multicolumn{2}{|c|}{ Monthly } & \multirow{2}{*}{$\begin{array}{c}\text { Days } \\
\text { above } \\
32.2^{\circ} \mathrm{C}\left(90^{\circ} \mathrm{F}\right)\end{array}$} & \multirow{2}{*}{$\begin{array}{c}\text { Days } \\
\text { below } \\
0^{\circ} \mathrm{C}\left(32^{\circ} \mathrm{F}\right)\end{array}$} & \multirow{2}{*}{$\begin{array}{c}\text { Days } \\
\text { below } \\
-17.8^{\circ} \mathrm{C}\left(0^{\circ} \mathrm{F}\right)\end{array}$} \\
\hline & & & $\begin{array}{l}\text { maximum } \\
\left({ }^{\circ} \mathrm{C}\right)\end{array}$ & $\underset{\left({ }^{\circ} \mathrm{C}\right)}{\operatorname{minimum}}$ & & & \\
\hline October & 16.6 & 4.2 & 23.3 & -0.6 & 0 & 7 & 0 \\
\hline November & 11.5 & 2.4 & 23.3 & -4.4 & 0 & 11 & 0 \\
\hline December & .6 & -10.3 & 11.7 & -21.1 & 0 & 31 & 5 \\
\hline January & 1.1 & -10.1 & 13.3 & -21.1 & 0 & 31 & 3 \\
\hline February & 1.8 & -6.9 & 12.8 & -17.8 & 0 & 28 & 2 \\
\hline March & 9.3 & -3.7 & 26.7 & -22.2 & 0 & 23 & 1 \\
\hline April & 14.9 & 1.7 & 27.8 & -4.9 & 0 & 13 & 0 \\
\hline May & 20.4 & 7.3 & 27.8 & -3.9 & 0 & 3 & 0 \\
\hline June & 24.6 & 10.3 & 29.4 & -1.1 & 0 & 1 & 0 \\
\hline July & 26.7 & 14.1 & 31.1 & 4.9 & 0 & 0 & 0 \\
\hline August & 24.3 & 10.2 & 29.4 & -.6 & 0 & 2 & 0 \\
\hline September & 22.8 & 10.4 & 28.9 & 0 & 0 & 1 & 0. \\
\hline
\end{tabular}


Table 5.--Monthly temperature statistics at Stoystown, Pennsylvania, 1987 water year (adapted from NOAA, 1986-87) [ ${ }^{\circ} \mathrm{C}$, degrees Celsius; ${ }^{\circ} \mathrm{F}$, degrees Fahrenheit]

\begin{tabular}{|c|c|c|c|c|c|c|c|}
\hline \multirow[b]{2}{*}{ Month } & \multirow{2}{*}{$\begin{array}{l}\text { Average } \\
\text { maximum } \\
\left({ }^{\circ} \mathrm{C}\right)\end{array}$} & \multirow{2}{*}{$\begin{array}{c}\text { Average } \\
\text { minimum } \\
\left({ }^{\circ} \mathrm{C}\right)\end{array}$} & \multicolumn{2}{|c|}{ Monthly } & \multirow{2}{*}{$\begin{array}{c}\text { Days } \\
\text { above } \\
32.2^{\circ} \mathrm{C}\left(90^{\circ} \mathrm{F}\right)\end{array}$} & \multirow{2}{*}{$\begin{array}{l}\text { Days } \\
\text { below } \\
0^{\circ} \mathrm{C}\left(32^{\circ} \mathrm{F}\right)\end{array}$} & \multirow{2}{*}{$\begin{array}{l}\text { Days } \\
\text { below } \\
-17.8^{\circ} \mathrm{C}\left(0^{\circ} \mathrm{F}\right)\end{array}$} \\
\hline & & & $\underset{\left({ }^{\circ} \mathrm{C}\right)}{\max \text { imum }}$ & $\underset{\left({ }^{\circ} \mathrm{C}\right)}{\operatorname{minimum}}$ & & & \\
\hline October & 16.1 & 2.6 & 25.6 & -5.0 & 0 & 14 & 0 \\
\hline November & 7.9 & -3.3 & 19.9 & -17.2 & 0 & 24 & 0 \\
\hline December & 2.2 & -7.2 & 12.2 & -16.1 & 0 & 31 & 0 \\
\hline January & -.7 & -11.3 & 9.9 & -23.3 & 0 & 31 & 8 \\
\hline February & 2.8 & -10.2 & 8.9 & -20.0 & 0 & 28 & 3 \\
\hline March & 9.2 & -5.4 & 22.2 & -15.0 & 0 & 28 & 0 \\
\hline April & 13.4 & .7 & 26.7 & -5.6 & 0 & 15 & 0 \\
\hline May & 22.6 & 7.2 & 29.4 & -3.9 & 0 & 3 & 0 \\
\hline June & 25.6 & 10.9 & 29.9 & -2.8 & 0 & 0 & 0 \\
\hline July & 28.3 & 14.0 & 31.7 & 6.7 & 0 & 0 & 0 \\
\hline August & 27.1 & 10.8 & 33.9 & 2.8 & 3 & 0 & 0 \\
\hline September & 21.8 & 8.2 & 25.6 & -2.2 & 0 & 1 & 0 \\
\hline
\end{tabular}

Table 6.--Monthly temperature statistics at Stoystown, Pennsylvania, 1988 water year (adapted from NOAA, 1987-88) [ ${ }^{\circ} \mathrm{C}$, degrees Celsius; ${ }^{\circ} \mathrm{F}$, degrees Fahrenheit; --, no data]

\begin{tabular}{|c|c|c|c|c|c|c|c|}
\hline \multirow[b]{2}{*}{ Month } & \multirow{2}{*}{$\begin{array}{l}\text { Average } \\
\text { maximum } \\
\left({ }^{\circ} \mathrm{C}\right)\end{array}$} & \multirow{2}{*}{$\begin{array}{c}\text { Average } \\
\text { minimum } \\
\left({ }^{\circ} \mathrm{C}\right)\end{array}$} & \multicolumn{2}{|c|}{ Monthly } & \multirow{2}{*}{$\begin{array}{c}\text { Days } \\
\text { above } \\
32.2^{\circ} \mathrm{C}\left(90^{\circ} \mathrm{F}\right)\end{array}$} & \multirow{2}{*}{$\begin{array}{c}\text { Days } \\
\text { below } \\
0^{\circ} \mathrm{C}\left(32^{\circ} \mathrm{F}\right)\end{array}$} & \multirow{2}{*}{$\begin{array}{c}\text { Days } \\
\text { below } \\
-17.8^{\circ} \mathrm{C}\left(0^{\circ} \mathrm{F}\right)\end{array}$} \\
\hline & & & $\begin{array}{c}\max i m u m \\
\left({ }^{\circ} \mathrm{C}\right)\end{array}$ & $\underset{\left({ }^{\circ} \mathrm{C}\right)}{\operatorname{minimum}}$ & & & \\
\hline October & 13.1 & -1.7 & 22.8 & -7.8 & 0 & 22 & 0 \\
\hline November & 10.9 & -2.2 & 22.8 & -13.9 & 0 & 22 & 0 \\
\hline December & 3.6 & -6.8 & 13.3 & -15.0 & 0 & 31 & 0 \\
\hline January & .9 & -14.2 & 13.9 & -23.3 & 0 & 31 & 12 \\
\hline February & 1.8 & -11.2 & 13.3 & -23.9 & 0 & 28 & 8 \\
\hline March & 8.8 & -5.6 & 23.9 & -16.7 & 0 & 30 & 0 \\
\hline April & -- & -- & -- & -- & -- & -- & -- \\
\hline May & 21.6 & 5.6 & 28.9 & -2.2 & 0 & 2 & 0 \\
\hline June & 25.1 & 7.3 & 32.2 & -2.2 & 1 & 4 & 0 \\
\hline July & 27.5 & 12.2 & 36.7 & 2.8 & 7 & 0 & 0 \\
\hline August & 25.1 & 11.5 & 31.1 & 3.3 & 0 & 0 & 0 \\
\hline Sept ember & 18.1 & 5.7 & 22.2 & -0.6 & 0 & 3 & 0 \\
\hline
\end{tabular}


Snowfall-accumulation data are also important for both geochemical and hydrologic interpretations. Snowfall information was not collected at the study site. The NOAA weather station at Boswel1 maintained snowfa11-depth records from 1960 to 1983 . For this period of record, the average annual snowfall is about 69.5 inches. Figure 6 shows the months when snowfall accumulated. January and February had the highest average snowfall amounts of 18.2 and 19.2 in., respectively. Snowfall accumulation typically occurs from October to April.

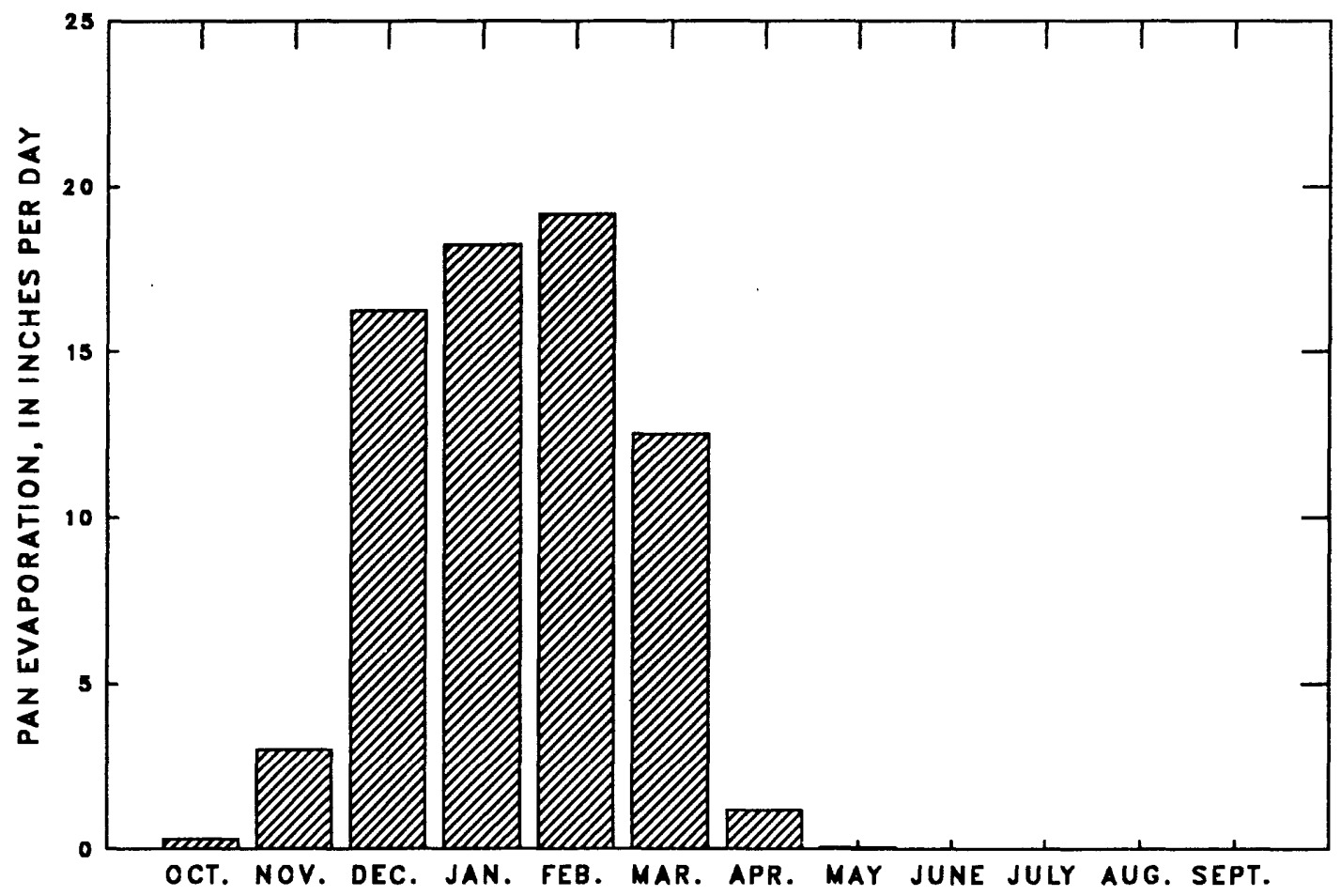

Figure 6.--Average monthly snowfall accumulation on ground at Boswell, Pennsylvania, 1960-83.

Information on wind speed is necessary for calibrating hydrologic simulation models and may also be important in interpretating future collections of soil-water and soil-gas data. In model calibration, wind speed is used to simulate the rate of sublimation of the snow pack and the variation of snow pack depth as a result of sublimation.

Wind speed was not recorded on site; few NOAA climatological stations are equipped with the instrumentation for recording it. The closest NOAA climatological station recording these data is $64.5 \mathrm{mi}$ west at Pittsburgh International Airport in Allegheny County, Pennsylvania. Data from this station probably are not representative of the study area because of the wind diversion created by Laurel Hill. However, information provided by the National Climatic Center, (oral commun., 1983), indicates that the prevailing wind for Somerset County is from the southwest and that average wind speeds are highest at $11 \mathrm{mi} / \mathrm{hr}$ (miles per hour) in winter. 
Solar radiation is used as a time-series for simulating soil heating, radiation heat flux to snow packs, and relative air temperatures resulting from back radiation off of reflective surfaces. Solar radiation coupled with temperature is important in the simulation of snowmelt. Also, it can be equally important in the interpretation of geochemical model results of surface-water, ground-water, and soil-water data.

Solar radiation is not normally recorded at NOAA climatological stations and has not been collected at any station in western Pennsylvania since 1980 (National Climatic Center, oral commun., 1988). The closest NOAA station with a long-term record prior to 1980 is at Pittsburgh International Airport. Figure 7 shows average daily "Engineering Corrected Solar Radiation" for 23 years of record (James I. Sams, U.S. Geological Survey, written commun., 1988). "Engineering Corrected Solar Radiation" data were obtained from pyranometers corrected for known scale changes, station moves, recorders, and sensor calibration changes, and angles of incidence (National Climatic Center, 1981). Typically higher solar radiation occurs during the growing season from late April to early September and the most intense period is from late May to early June.

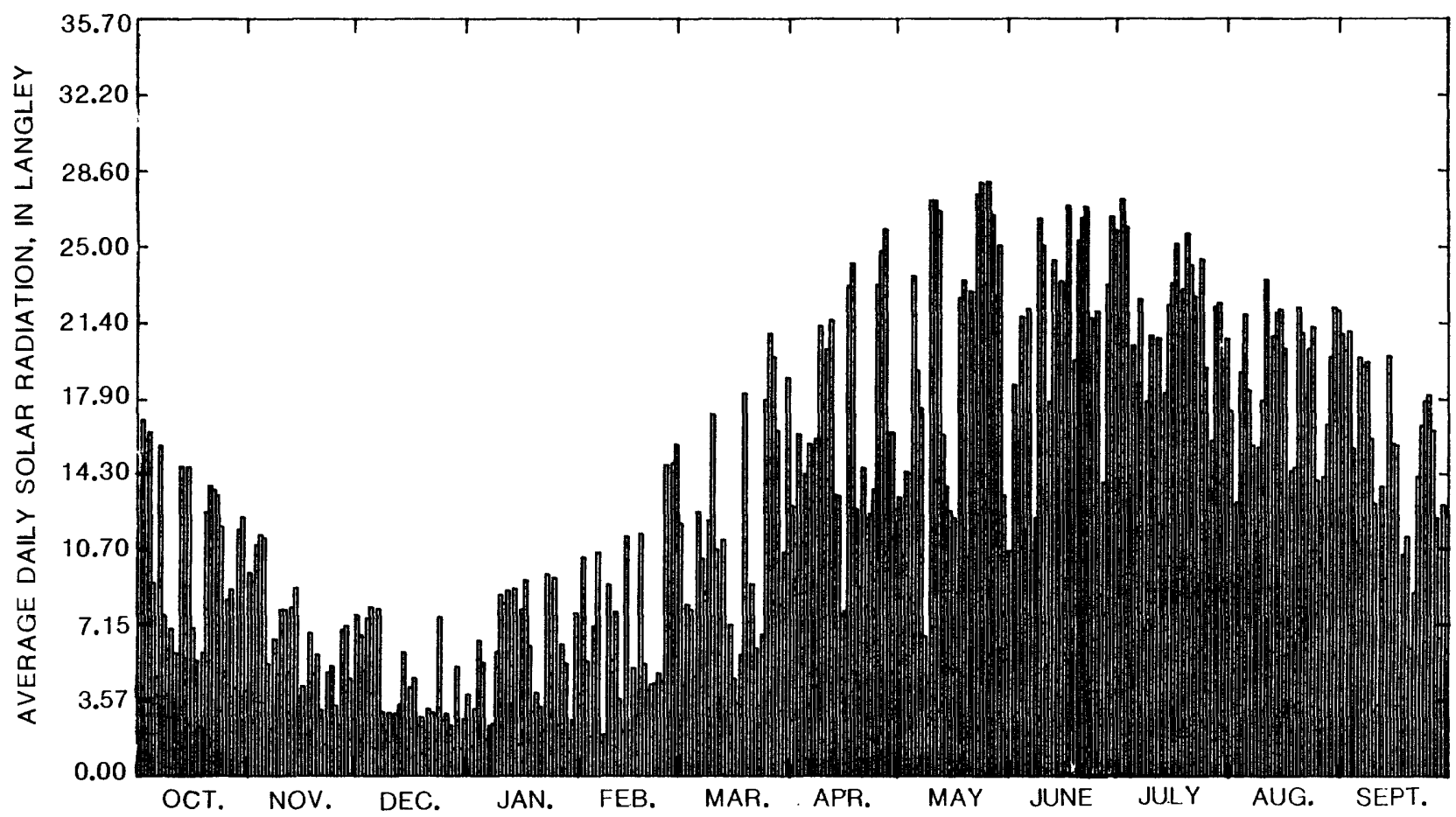

Figure 7.--Average daily "Engineering Corrected Solar Radiation" for southwestern Pennsylvania.

Pan-evaporation data are a necessary time-series for computing annual water balances. Genera11y, pan-evaporation data are converted to lakeevaporation data by a multiplication factor of 0.70 (Farnsworth and others, 1982). A typical computer model will then determine the amount of evapotranspiration on the basis of these lake-evaporation data and other 
climatological characteristics. Evapotranspiration can account for 30 to 50 percent of the net water loss in hydrologic budgets for the study area (Barker and Witt III, 1990).

The closest NOAA climatological station that records pan-evaporation data is in Confluence, Pennsylvania, which is about $37 \mathrm{mi}$ south of the study area. Daily tables of pan evaporation are not reproduced in this report because the data are easily accessed by most computer systems. The data are also

available from the National Oceanic and Atmospheric Administration (1983 to 1988).

Pan evaporation averages 0.17 inches per day (in/day) during the growing season and 0.02 in/day during the nongrowing season. Figure 8 shows average monthly pan evaporation for 1984-87. Pan evaporation is consistently the highest in June and July. Data shown in figure 8 are from Confluence and have been corrected for periods of missing data by using temperature and averaged pan-evaporation values for previous years (D.R. Schild, U.S. Geological Survey, written commun., 1988).

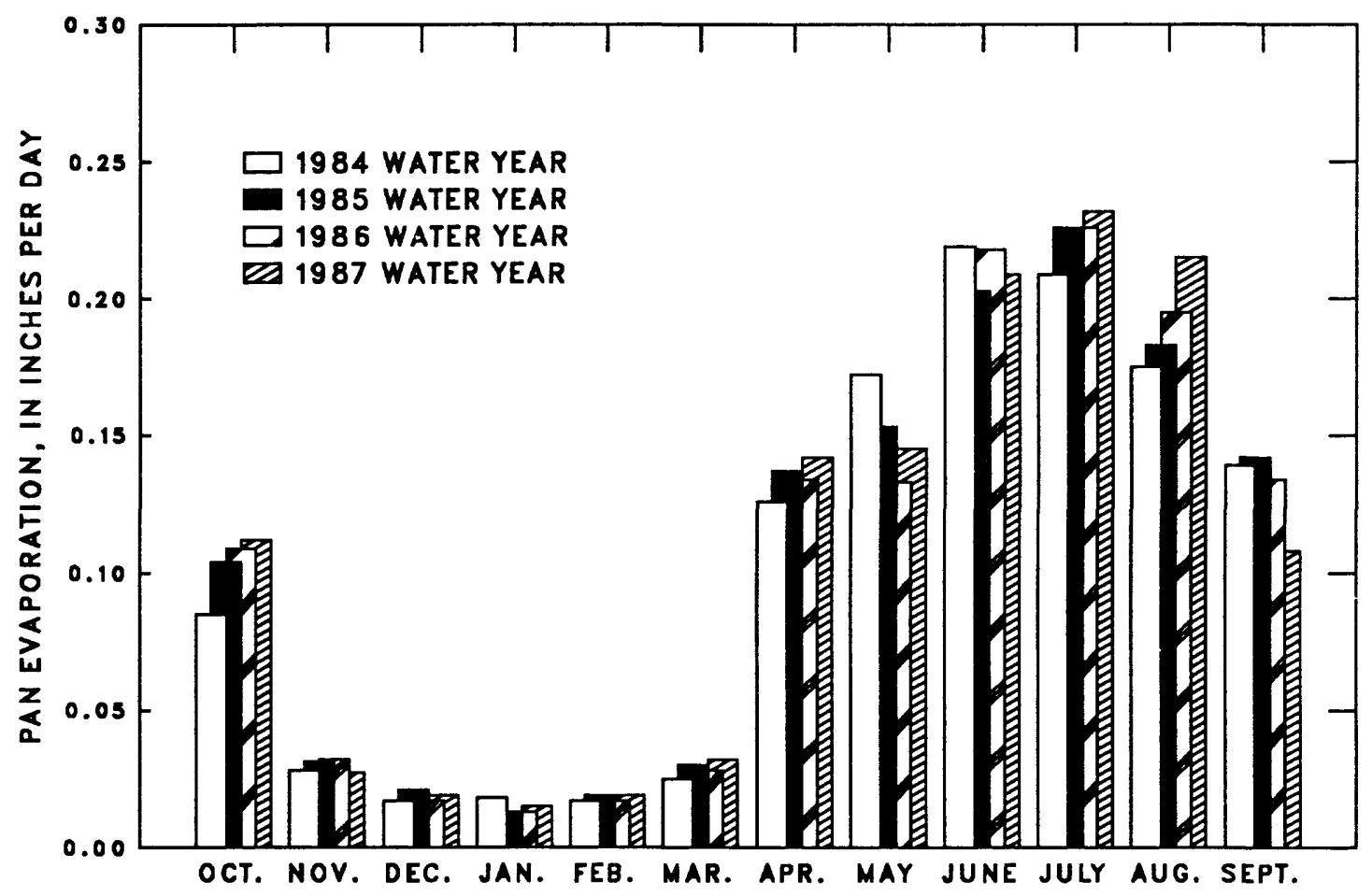

Figure 8.--Average monthly pan evaporation for water years 1984-87. 


\section{Air Quality}

Air quality of the area surrounding North Fork Bens Creek is important because pollution and particulates in the atmosphere can affect the quality of precipitation and, ultimately, can cause chemical fluctuations in the stream. Air quality is monitored in Pennsylvania by three state agencies: the Pennsylvania Bureau of Air Quality Control, the Allegheny County Health Department, and the Philadelphia Air Management Services. These agencies maintain a network of air quality data-collection stations for 13 "air basins" within Pennsylvania (Pennsylvania Department of Environmental Resources, 1986). Those "air basins" representative of western Pennsylvania are: Johnstown, Mon Valley, Upper Beaver, and Lower Beaver. Data collection for these "air basins" involves weekly samples of sulfates, nitrates, lead, beryllium, and benzo- $\alpha$-pyrene, and monthly samples for settleable particulate matter by means of a dustfall jar. These data, including a detailed description of the "air basin" criteria, are published by the Pennsylvania Department of Environmental Resources (1984 and 1986).

In addition to the 13 "air basins", three additional "non-air basin" areas have substantial monitoring programs. A "non-air basin" is an airquality region that can enclose several counties. This is unlike the "air basins" that consider air quality within a smaller perimeter, such as the boundaries of major cities or metropolitan areas. The "non-air basin" that is most representative of the study area on the basis of prevailing wind direction is the Region Five "non-air basin". This area involves eight sites within a region encompassing Beaver, Allegheny, Washington, Greene, Fayette, Westmoreland, Armstrong, Indiana, Cambria, and Somerset Counties. Data collected at these "non-air basin" sites include: sulfate, nitrate, sulfur dioxide, nitrogen dioxide, and total suspended particulates. "Non-air basin" data also are published by the Pennsylvania Department of Environmenta1 Resources (1984 and 1986).

Four air-quality constituents sampled within both the "air basin" and "non-air basins" networks are especially important for the interpretation of the data in this report. These constituents are: sulfur dioxide, nitrogen dioxide, sulfates, and nitrates.

Sulfur dioxide is a contaminant that is emitted primarily by factories or power plants burning coal or oil containing sulfur (Pennsylvania Department of Environmental Resources, 1986). Data for this constituent are collected by a pulsed fluorescence monitor. Sulfur-dioxide concentrations in Pennsylvania have generally decreased from 1977 to 1986 for all "air basins" representative of western Pennsylvania except Johnstown (Pennsylvania Department of Environmental Resources, 1986). Similarly, sulfur dioxide at the Region Five "non-air basin" sites also has decreased during the same time period.

Annual nitrogen-dioxide concentrations during 1976-86 were relatively constant with the exception of the Johnstown "air basin" (Pennsylvania Department of Environmental Resources, 1986). Nitrogen dioxide is a highly toxic red-brown gas that is emitted primarily from the combustion of fuels in either stationary or transportation sources. Nitrogen dioxide and other oxides of nitrogen are monitored in Pennsylvania by chemiluminescent 
analyzers. The Region Five "non-air basin" is missing data from 1975 through 1983; and therefore, no trend was detected.

Sulfates are of special interest in water-quality studies because of their close association with acid precipitation. Sulfates in the atmosphere are of two types: primary and secondary. Primary sulfates are emitted directly into the atmosphere from industrial processes. Secondary sulfates are formed in the atmosphere from other sulfur-containing compounds under mechanisms that involve photochemical processes.

A 30-day standard for sulfate has been adopted from the National Ambient Air Quality Standards. The 30-day standard is an operational statistic used by air quality managers for determining unhealthy levels of sulfate in the air. Sulfate concentrations over a 30-day period are averaged and compared with the 30 -day standard. The standard for Pennsylvania is $10 \mu \mathrm{g} / \mathrm{m}^{3}$ (micrograms per cubic meter). Al1 air quality monitoring stations have exceeded this standard from 1975 through 1984. Although the 30-day standard had been continually violated, air basins in southwestern Pennsylvania have shown a downward trend in sulfate concentration from 1977 through 1986. Sulfate concentrations have decreased from 23 to $14 \mu \mathrm{g} / \mathrm{m}^{3}$ within the Johnstown "air basin" during this ten-year period. Maximum monthly concentration mostly occurred during June through September.

Nitrates are constituents whose association with acid precipitation are being studied. They are particulate compounds that are usually formed in the atmosphere from nitrogen oxide gases. Nitrates throughout the state have remained relatively constant for the 10 -year period of record. There are no state air quality standards for nitrates (Pennsylvania Department of Environmental Resources, 1986).

An emissions inventory of sulfur oxides and nitrogen oxides for nearly 700 facilities across Pennsylvania is compiled by the Pennsylvania Department of Environmental Recources (Bureau of Air Quality Control, 1987). Because general wind direction at the study area is from the west-southwest, transport of emission gases and particulates to the watershed may affect precipitation quality. Basin soils may also be affected by deposition of air-borne particulate matter. Figure 9 shows the emission densities of sulfur oxides for counties in western Pennsylvania. Although the study area is within a county of very low sulfur oxide emissions, adjacent western counties and those bordering West Virginia have high emission densities. Precipitation events from the west-southwest are therefore likely to transport these contaminants to the North Fork Bens Creek basin.

Nitrogen-oxide emissions are generally about 25 percent lower than sulfates for counties west of the study area (fig. 9). Nitrate concentrations in samples of precipitation collected in the Laurel Hill area suggest that the nitric acid component of precipitation acidity is minimal (Barker and Witt III, 1990). 


\section{SULFUR OXIDE EMISSIONS}

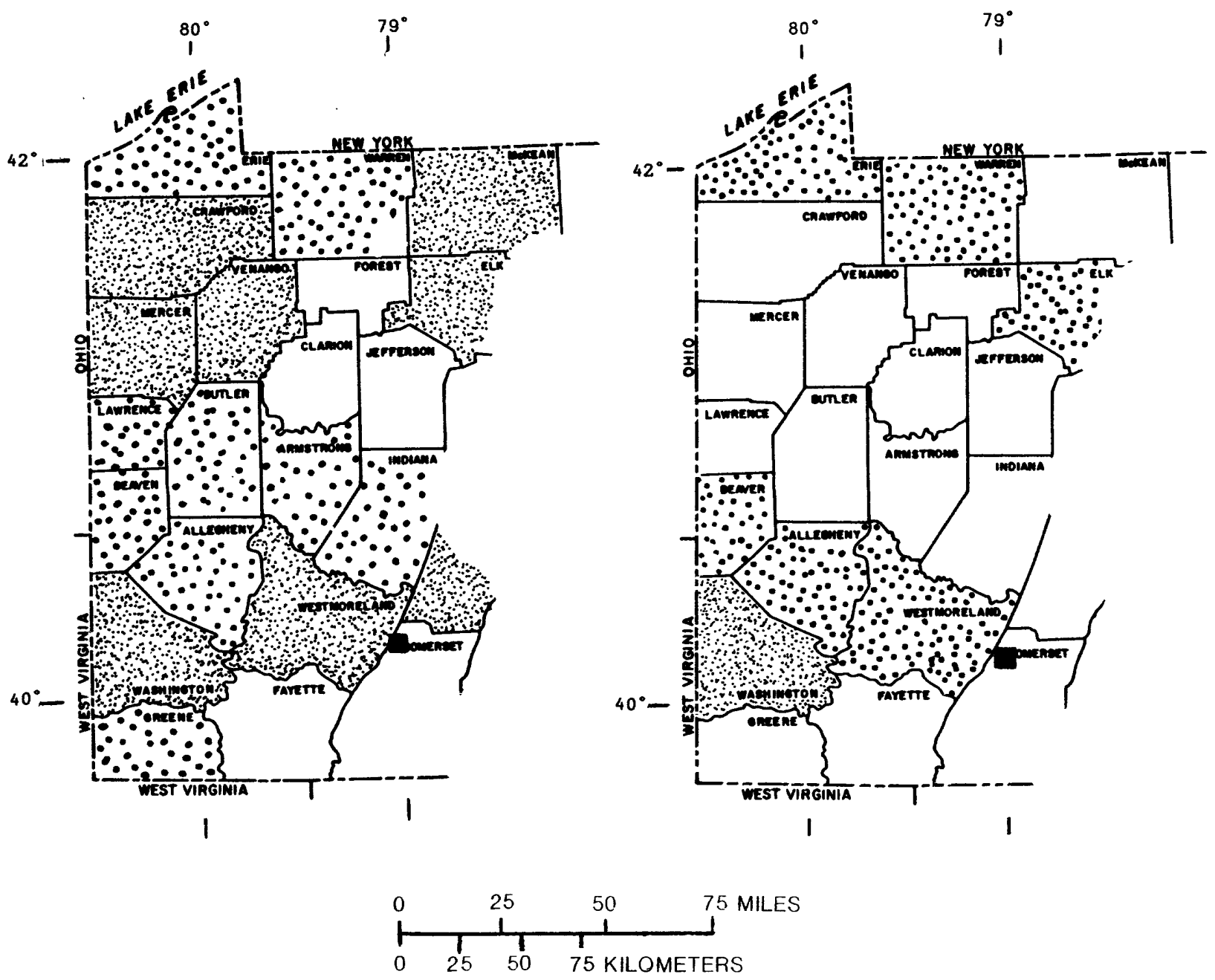

EXPLANATION

TONS PER YEAR

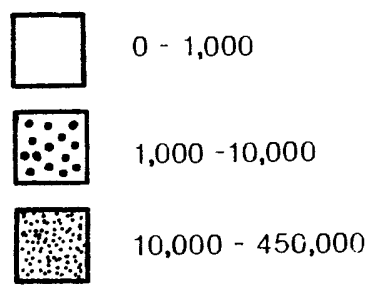

STUDY AREA

Figure 9.--Densities of sulfur oxides and nitrogen oxides emissions for counties in western Pennsylvania.

(Adapted from Bureau of Air Quality, 1987). 


\section{Precipitation Quality}

The quality of precipitation has been shown to cause temporary changes in stream quality during runoff episodes (Walling and Foster, 1975; Sharpe and others, 1987; Barker and Witt III, 1990). Therefore, it is necessary to provide the chemical characteristics of precipitation affecting the study area.

Western Pennsylvania is within a region of the United States with the highest average precipitation hydrogen ion concentration. Likens (1976) reported that precipitation $\mathrm{pH}$ for the eastern United States for 1955-56 and 1972-73 was lowest in an area encompassing western Pennsylvania, New York, New Hampshire, and Vermont. In this region, $\mathrm{pH}$ decreased from 4.52 in 1955 , to 4.22 in 1972. Measurements of $\mathrm{pH}$ of precipitation in the study area in 1984 suggested a further increase in precipitation hydrogen ion concentration (Barker and Witt III, 1990). Average volume-weighted $\mathrm{pH}$ for the study area is reported to be about 4.00. Data from the National Acid Precipitation Assessment Program show similar volume-weighted precipitation $\mathrm{pH}$ for the northeastern United States (fig. 10).

From September 1983 to July 1985, weekly samples of precipitation from the Laurel Hill area were analyzed for $\mathrm{pH}$ and specific conductance and sent to the laboratory for other analyses. These data are not reproduced in this report but can be found in Barker and Witt III (1990). Barker and Witt III (1990) indicate that hydrogen and sulfate are the dominant ions in the composition of precipitation averaging 33 and 32 percent, respectively. Nitrate, on the other hand, averaged about 15 percent of the total ionic composition, cations 10 percent, and chloride 3 percent.

Similar precipitation-quality data were collected during 1985-87 at a Laurel Hill site $28 \mathrm{mi}$ southwest of North Fork Bens Creek. These data are published annually by the Environmental Resources Research Institute at the Pennsylvania State University for the Pennsylvania Department of Environmental Resources (Lynch and others, 1988). 

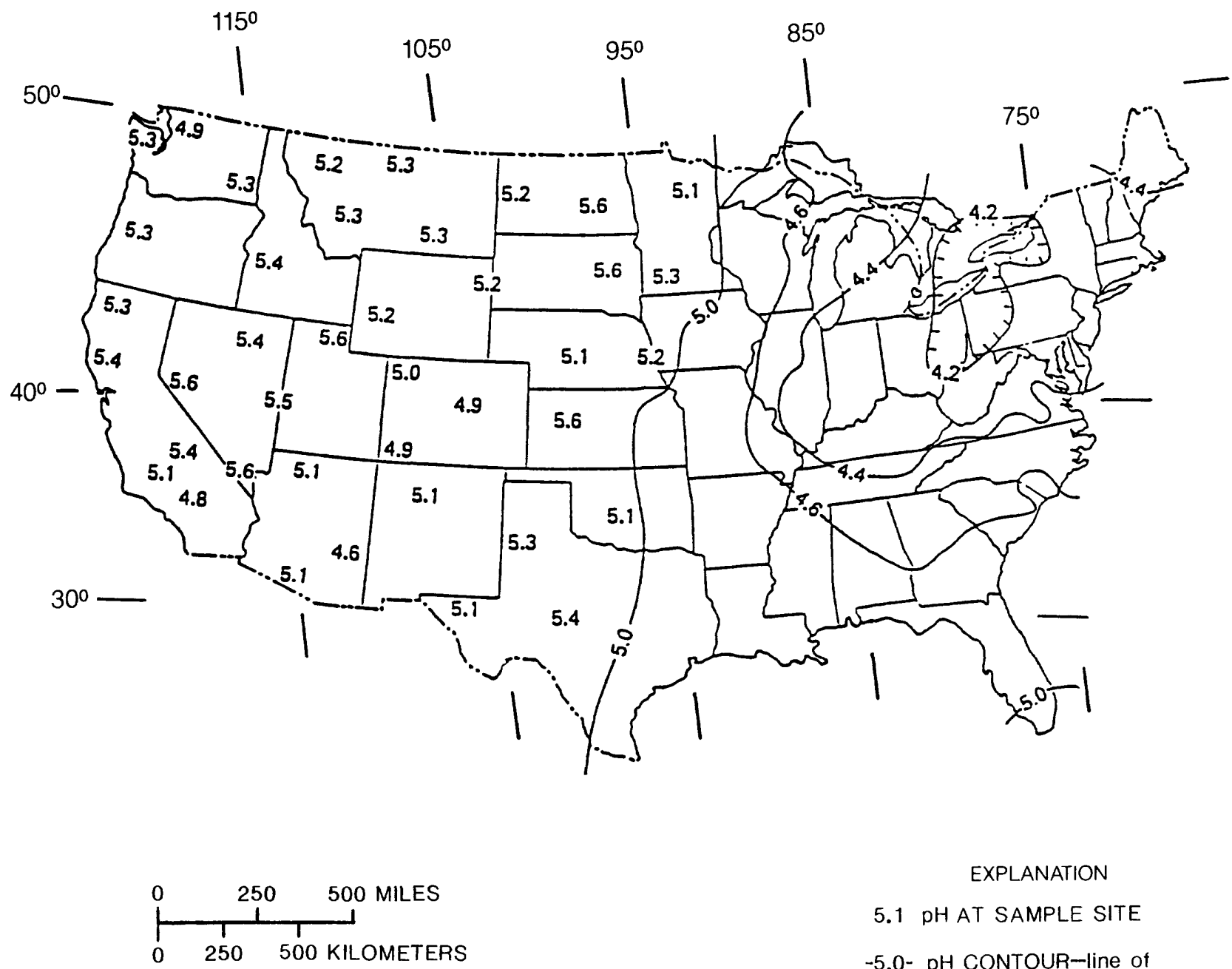

EXPLANATION

$5.1 \mathrm{pH}$ AT SAMPLE SITE

-5.0- $\mathrm{pH}$ CONTOUR-line of equal $\mathrm{pH}$ value

Figure 10-- $\mathrm{pH}$ of wet deposition (annual volume-weighted average) in the United States. Based on National Acid Precipitation Assessement Program and National Trends Network data (Modified from National Acid Precipitation Assessment Program, 1985, figure D-1). 


\section{Site Selection}

Prior to the beginning of study, the NAPAP Aquatics Affects Task Group compiled a selection protocol for potential research sites focusing primarily on understanding the processes controlling acidification of surface waters. Site selection for this study followed the NAPAP draft protocol as well as a protocol developed by the National Atmospheric Deposition Program (NADP) (Bigelow, 1982). The significant criteria for site selection outlined by both NAPAP and NADP were as follows:

1) Proposed study sites should not be adjacent to industrial activities (coal-fired power plants, steel mills, chemical plants).

2) The proposed study site should include streams or lakes without additions to its fluid medium by land-based cultural effluents (sewage, farm runoff, industrial discharge, mine drainage).

3). Small, easily monitored headwater streams and high-elevation lakes are preferred.

4) The stream or lake should be in an area where the surface waters are sensitive to acidic deposition--namely, in areas underlain by few or no carbonate-rock formations and having low soil-buffering capacity.

The North Fork Bens Creek was originally one of five sites in Pennsylvania selected for data collection in August 1983. These five sites were selected on the basis of the aforementioned criteria and were sampled for a period of $21 / 2$ years for the purpose of characterizing the quality of lowionic-strength headwater streams in the Laurel Hill region of southwestern Pennsylvania (Barker and Witt III, 1990). Following a reduction in funding, North Fork Bens Creek remained in the scaled-down data-collection program because it was the only site that continued to meet the NAPAP and NADP criteria. The other four sites were adversely affected by logging, land-use changes, and well-drilling operations and were discontinued. Also, North Fork Bens Creek is considered to be representative of headwater streams in the Laurel Highlands of southwestern Pennsylvania that have low ionic strength and low acid-neutralizing capacity (Barker and Witt III, 1990).

\section{Water-Quality Sampling Techniques}

Because each stream requires a sampling technique specifically to measure water quality for that site, NAPAP did not establish guidelines for sampling techniques. Each investigator constructed a field program tailored to sitespecific limitations. 
The monthly sampling program for North Fork Bens Creek involved handdipping a sample about midstream during base flow. The sample was collected in a 3-1iter polyethylene container. The container was then capped, stored in ice, and transported to the field laboratory where specific conductance, $\mathrm{pH}$, and acid-neutralizing capacity were determined within 1 hour of collection.

Generally, sampling water quality for the U.S. Geological Survey requires that the field personnel measure the stream discharge and then collect the water-quality sample from equal discharge or width increments. This method theoretically provides a representative sample of surface water from a site that may not be well mixed--a characteristic of large rivers. However, North Fork Bens Creek is a small stream (width of about $15 \mathrm{ft}$ ) with an average baseflow velocity of $0.91 \mathrm{ft} / \mathrm{s}$ (feet per second). The water is well mixed; therefore, no special method other than hand-dipping at about midstream is used. The same sampling section was used throughout the study--about $10 \mathrm{ft}$ upstream from the concrete weir.

\section{Field Measurement}

The specific conductance, $\mathrm{pH}$, temperature, and acid-neutralizing capacity (ANC) of streamflow and precipitation samples were measured in the field prior to sample preparation and shipment to the laboratory for analysis. Specific conductance was determined with a Beckman 1 RB-5 conductivity bridge with a cell constant of 0.1 . The cell constant was reconfirmed each month during calibration with a Beckman Model CEL-RB1-48F laboratory standard cell. Field $\mathrm{pH}$ was measured with a Ross combination $\mathrm{pH}$ electrode in conjunction with an Orion model 399A analog meter. The meter and electrode were calibrated at the beginning of each site visit using first a pH-7.0 buffer and then adjusting the slope with a $\mathrm{pH}-4.0$ buffer. A final check was made by immersing a calibrated electrode into a solution of distilled water saturated with carbon dioxide. This method provides a low ionic strength solution with a pH of 3.91 (Hydrolab Corporation, 1982). Temperature of an aliquot of the collected sample was measured with a mercury thermometer, certified by the National Bureau of Standards, as a precursor to measurement of $\mathrm{pH}$ and specific conductance. Acid-neutralizing capacity, or alkalinity, was determined using a modified Gran analysis procedure (Kramer, 1980). Instantaneous streamflow was measured during each sampling period with a Price current meter by the procedures described in Rantz (1982).

Field measurements are considered most representative of each monthly sample. Laboratory values for $\mathrm{pH}$, specific conductance, and alkalinity are not listed in the data tables unless field measurements were not available for a particular sample.

\footnotetext{
Use of brand names in this report is for identification purposes only and does not constitute endorsement by the U.S. Geological Survey.
} 


\section{Sample Preparation}

The U.S. Geological Survey Central Analytical Laboratory provided the project with all the shipping containers, required preservatives, and procedures for preparing aliquots of sample for laboratory analysis. Methods for preparing samples for shipment to the laboratory were not addressed in the original NAPAP draft protocol.

Three methods of sample preparation were used during data collection. The first method was established by the laboratory and used from August 1983 to September 1983. The second and third methods were the result of two meetings of a joint committee including the U.S. Geological Survey, Tennessee Valley Authority, and USEPA. The purpose of these meetings was to provide coordination between similar projects that were collecting long-term data in cooperation with the USEPA. Standardization and quality assurance of sample preparation was a serious concern because sample representativeness and intercomparability among the projects would be necessary for defending the results of the study. Each of the three methods of sample preparation was developed with successive improvement.

The first sample preparation procedure involved splitting the sample into five equal volumes (fig. 11). Each split was prepared for a specific set of constituents. Table 7 lists the constituents analyzed from each split.

Figure 11.--Sample preparation technique August 1983 through September 1983.

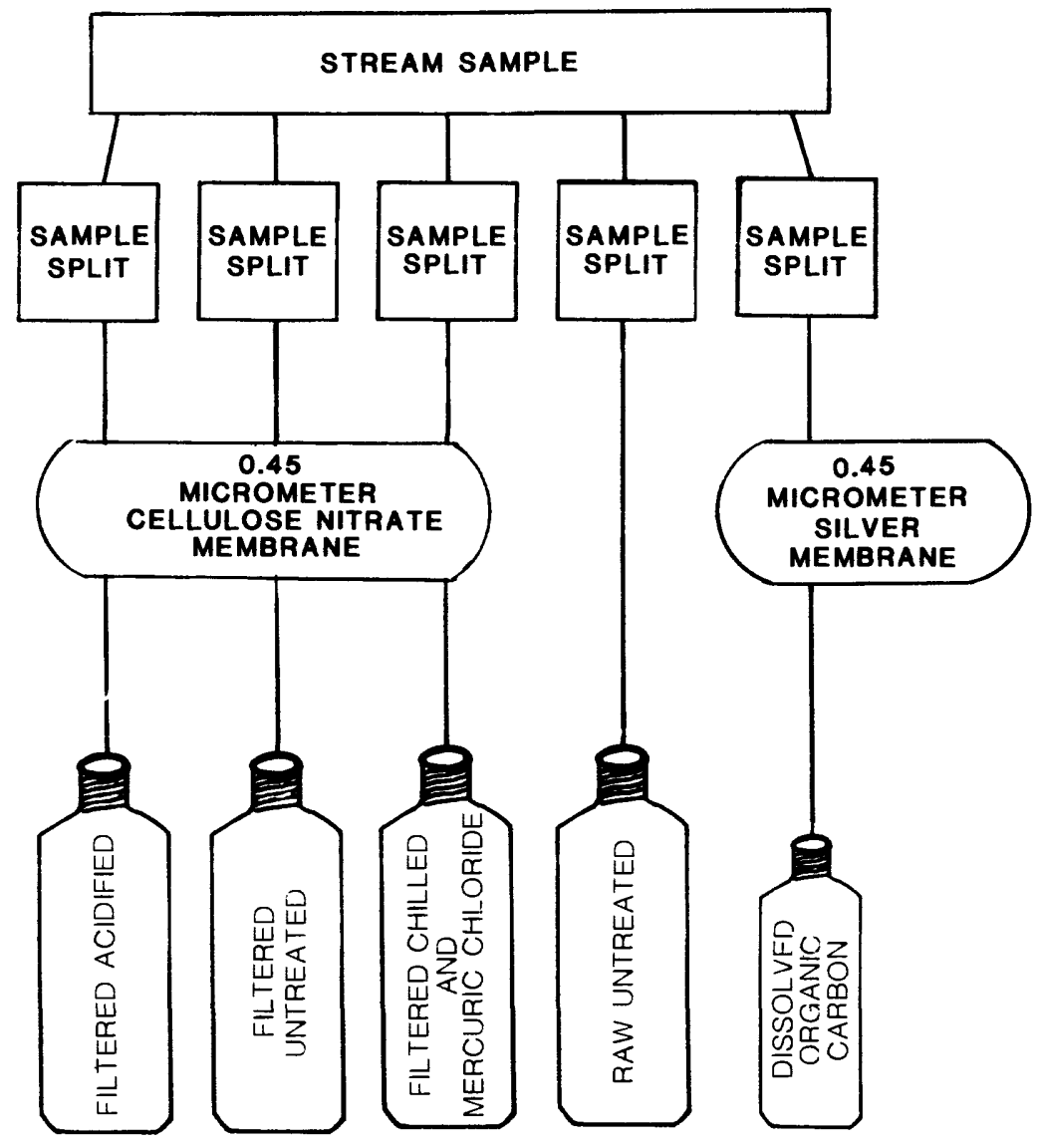


Table 7.--Chemical constituents analyzed from each sample split

[Diss., dissolved]

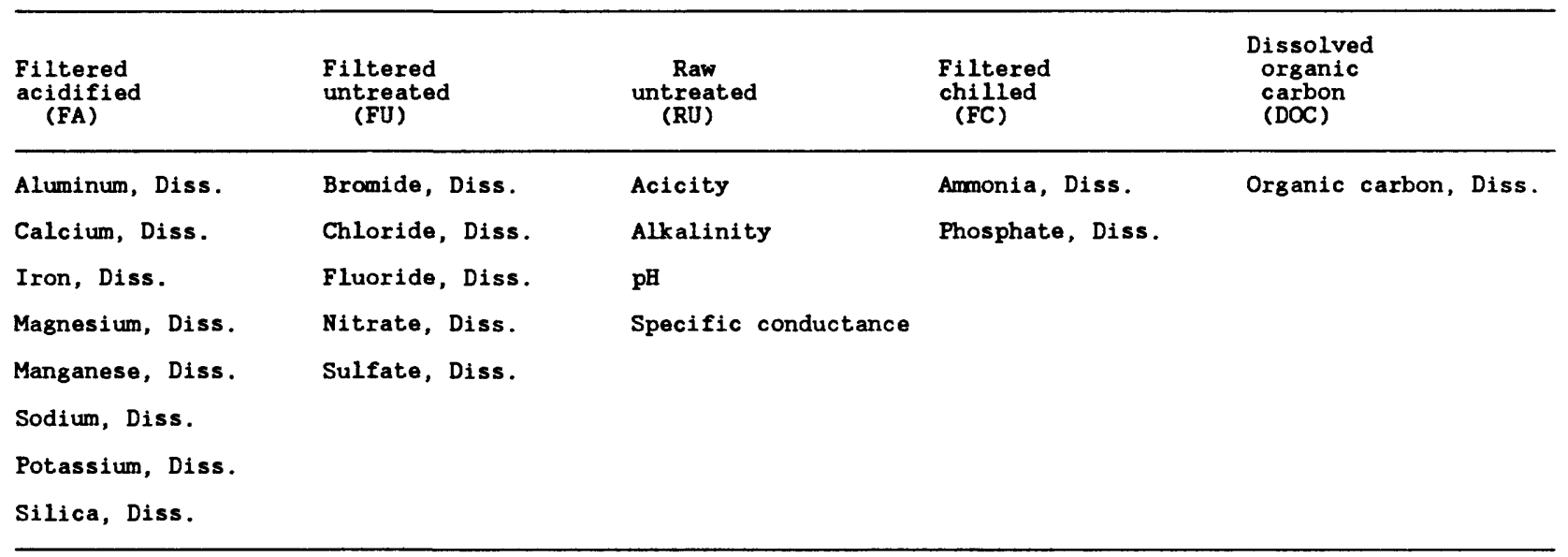

Three of the five splits were filtered through porous membranes into high density linear polyethylene (HDLP) containers. A split, designated filtered acidified (FA), was fiitered through $0.45-\mu \mathrm{m}$ (micrometer) cellulose nitrate membrane and then acidified to $\mathrm{pH}$ of 2.0 with high-purity acid. The filtered untreated (FU) split was also filtered through a $0.45-\mu \mathrm{m}$ cellulose nitrate membrane. No preservatives were added to this FU sample split. The filtered chilled (FC) split was filtered through a similar porosity membrane and a solid mercuric chloride preservative was added.

Two additional splits were prepared, one for determining the concentration of dissolved organic carbon (DOC) and the other, raw untreated (RU), for determining constituents such as $\mathrm{pH}$ and acidity. The split for DOC was filtered through a Gellam stainless steel filtration apparatus containing a $0.45-\mu \mathrm{m}$ silver membrane. This split was shipped in a $100-\mathrm{mL}$ (milliliter) glass bottle. The RU split was introduced unfiltered into a clean HDLP container--no preservatives were added. Table 8 lists the labels for each container and the required and submitted volume for each sample split.

Table 8.--Split volumes and preservation criteria

[in milliliters]

\begin{tabular}{|c|c|c|c|c|c|}
\hline & $\begin{array}{l}\text { Filtered } \\
\text { acidified } \\
\text { (FA) }\end{array}$ & $\begin{array}{l}\text { Filtered } \\
\text { untreated } \\
\text { (FU) }\end{array}$ & $\underset{\substack{\text { Raw } \\
\text { (RU) }}}{(\mathrm{RU})}$ & $\begin{array}{l}\text { Filtered } \\
\text { chilled } \\
\text { (FC) }\end{array}$ & $\begin{array}{l}\text { Dissolved } \\
\text { organic } \\
\text { carbon } \\
\text { (DOC) }\end{array}$ \\
\hline Required volume ${ }^{1}$ & 100 & 100 & 100 & 50 & 100 \\
\hline Submitted volume ${ }^{2}$ & 250 & 250 & 250 & 250 & 100 \\
\hline Nitric acid added & Yes & No & No & No & No \\
\hline Mercuric chloride added ${ }^{3}$ & No & No & No & Yes & No \\
\hline
\end{tabular}

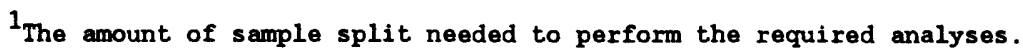

${ }^{2}$ Additional volume for laboratory storage in case reanalysis is necessary.

${ }^{3}$ The addition of $\mathrm{HgCl}$ was omitted from sample preparation beginning December 1984.
} 
All splits were packed in ice for shipment to the laboratory. Samples received warm were noted by the laboratory and the principle investigator was notified immediately.

Following the first joint meeting, filter-porosity changes were made in the sample preparation procedure. The FC and FU splits were still filtered through $0.45-\mu \mathrm{m}$ cellulose nitrate membranes. The FA split, however, was prepared by filtering the sample split through a $0.20-\mu \mathrm{m}$ polycarbonate membrane. This change in sample preparation was implemented to define the concentration of total dissolved aluminum in the sample more accurately. This second preparation procedure remained in effect from October 1983 through August 1984 (fig. 12).

The final method agreed upon by the joint committee included another change in filter porosity. This time a $0.1-\mu \mathrm{m}$ polycarbonate membrane was used for filtering sample water for the FA, FU, and FC splits (fig. 13). The DOC and RU splits were prepared in the same manner as the previous two procedures. The mercuric chloride preservative previously used for preparation of the FC split was determined unnecessary because the split was now filtered through a $0.1-\mu \mathrm{m}$ membrane. No mercuric chloride preservative was used during the remainder of the study. The third and final preparation procedure was used from October 1984 through September 1988.

Figure 12.--Sample preparation technigue October 1983 through August 1984.

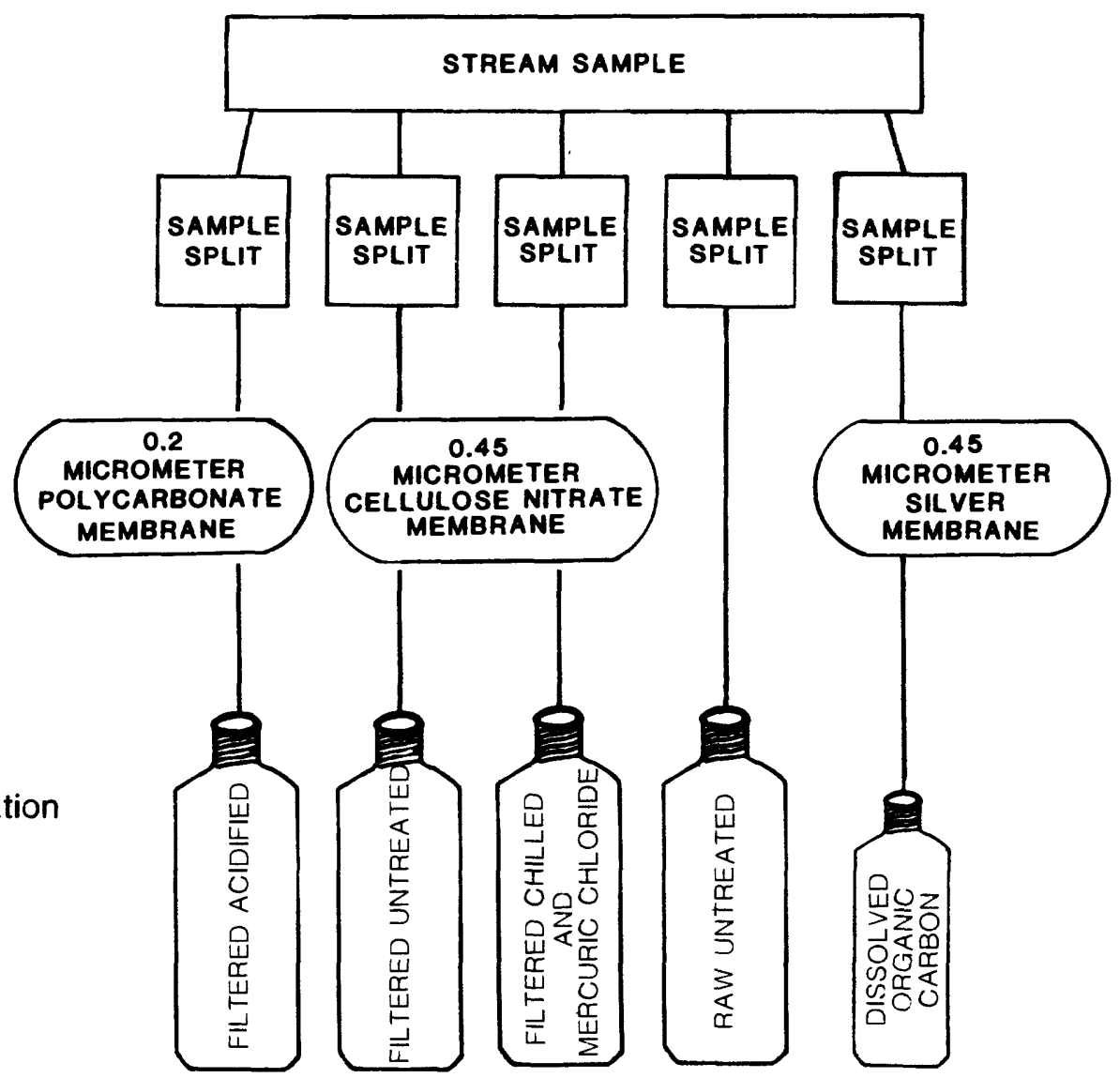




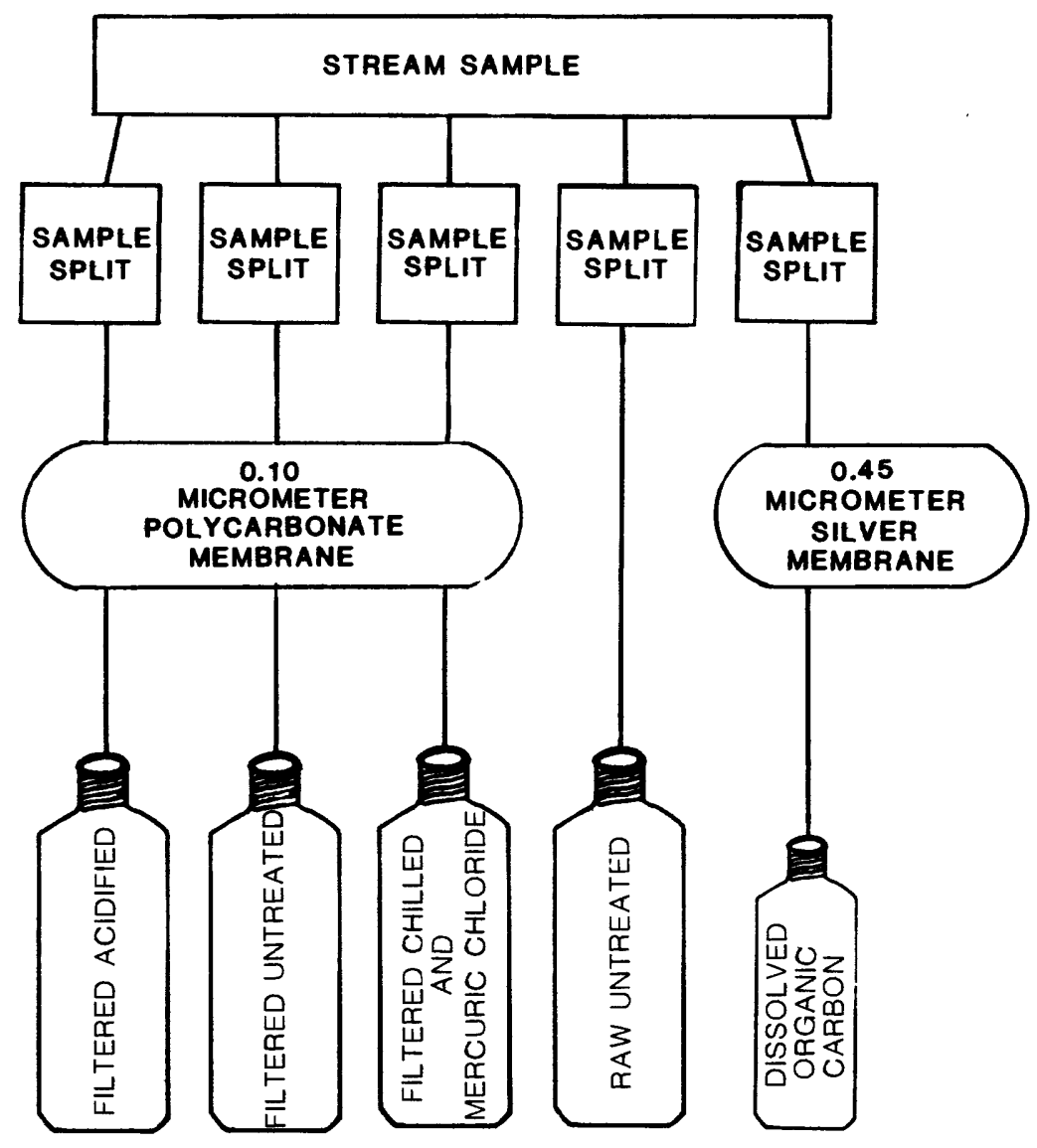

Figure 13.--Sample preparation technique September 1984 through September 1988.

\section{Analytical Services}

The collected samples were analyzed in the U.S. Geological Survey laboratories in Atlanta, Georgia, and Arvada, Colorado. Chemical constituents, analytical methods, and reporting levels for the project are listed in table 9. Information on techniques used for each analytical method are found in Skougstad and others (1979). Laboratory quality-assurance practices are described by Friedman and Erdmann (1982).

In addition to the changes in sample-preparation procedure during the project, the laboratory location also changed at the beginning of the project. Initially all samples were submitted to the U.S. Geological Survey laboratory in Atlanta, Georgia. During the first year of study, the Atlanta laboratory began phasing out operations and was unable to equip their staff with the instrumentation necessary for analyzing low-ionic-strength samples at the precision needed for the project. Because of this inadequacy, all samples were submitted to the U.S. Geological Survey, Central Analytical Laboratory in Denver, Colorado, beginning in October 1984. A special section of this laboratory was dedicated to the analysis of low-ionic-strength solutions. Also, beginning in March 1985, the procedure for determining alkalinity and acidity in the laboratory was upgraded from endpoint titration to the secondderivative method. 
Table 9.--Laboratory analytical methods and reporting levels for stream samples

[Reporting level milligrams per liter, except as noted; $\mu \mathrm{S} / \mathrm{cm}$, microsiemens per centimeter at $25^{\circ} \mathrm{C} ; \mu \mathrm{g} / \mathrm{L}$, micrograms per 1iter]

\begin{tabular}{|c|c|c|}
\hline Chemical constituent & Analytical method & $\begin{array}{l}\text { Reporting } \\
\text { level }\end{array}$ \\
\hline Acidity as $[\mathrm{H}+]$ & $\begin{array}{l}\text { Electrometric titration (second } \\
\text { derivative method) }\end{array}$ & 0.01 \\
\hline $\begin{array}{l}\text { Acid neutralizing capacity } \\
\text { [Total alkalinity] }\end{array}$ & $\begin{array}{l}\text { Electrometric titration (second } \\
\text { derivative method) }\end{array}$ & .5 \\
\hline Aluminum, dissolved & Atomic absorption spectroscopy & .05 \\
\hline Calcium, dissolved & Atomic absorption spectroscopy & .005 \\
\hline Bromide, dissolved & Ion chromatography & .01 \\
\hline Chloride, dissolved & Ion chromatography & .01 \\
\hline Fluoride, dissolved & Ion chromatography & .01 \\
\hline Nitrate, dissolved & Ion chromatography & .01 \\
\hline Sulfate, dissolved & Ion chromatography & .01 \\
\hline Iron, dissolved & Atomic absorption spectroscopy & $2 \mu \mathrm{g} / \mathrm{L}$ \\
\hline Magnesium, dissolved & Atomic absorption spectroscopy & .01 \\
\hline Manganese, dissolved & Atomic absorption spectroscopy & $2 \mu \mathrm{g} / \mathrm{L}$ \\
\hline $\mathrm{pH}$ & Electrometric titration & .1 units \\
\hline Potassium, dissolved & Atomic absorption spectroscopy & .01 \\
\hline Silica, dissolved & Atomic absorption spectroscopy & .01 \\
\hline Sodium, dissolved & Atomic absorption spectroscopy & .01 \\
\hline Specific conductance & Wheatstone bridge & 1. $\mu \mathrm{S} / \mathrm{cm}$ \\
\hline Carbon, organic, dissolved & Wet oxidation & .1 \\
\hline $\begin{array}{l}\text { Nitrogen ammonia as } \mathrm{N} \text {, } \\
\text { dissolved }\end{array}$ & Colorimetry, hypochlorite & .001 \\
\hline $\begin{array}{l}\text { Phosphate ortho - P, } \\
\text { dissolved }\end{array}$ & Colorimetry, phosphomolybdate & .001 \\
\hline
\end{tabular}




\section{Instrumentation}

Two types of continuous data were collected during the life of the project--streamflow and precipitation. Streamflow was not continuously monitored throughout the study period because of funding reductions, but the methodologies remained consistent for those periods of collection. Precipitation on the other hand, was continuously monitored throughout the study by two different techniques.

\section{Streamflow Data Collection}

Streamflow was monitored using a U.S. Geological Survey STATCOM MANOMETER coupled with an Analytical Digital Recorder. Installation procedures for the STATCOM MANOMETER are described by Craig (1983). From October 1984 through September 1985, the equipment was maintained weekly and record removed monthly. From October 1987 through September 1988, maintenance and record removal both were done monthly. Procedures described by Rantz (1982) were used to maintain the streamflow station.

\section{Precipitation Data Collection}

Precipitation-quantity data were originally collected using a weighing bucket type gage. The gage was maintained and the data chart was removed weekly according to NADP protocol. The gage was calibrated monthly. A National Weather Service standard rain gage was installed near the weighing bucket gage to check weekly totals. Measurements of precipitation by the weighing bucket precipitation gage began in October 1983 and continued until September 1985. From October 1985 through September 1988, an electronic tipping bucket precipitation gage was used. Data from this gage were recorded on an analytical digital recorder and transferred to a U.S. Geological Survey data base where values were checked with those from a nearby NOAA climatological station.

The weighing-bucket gage was replaced with the electronic tipping-bucket gage because of funding limitations and the economics of field maintenance. The weighing-bucket precipitation gage required weekly maintenance.

Maintenance of the tipping bucket gage, on the other hand, could be done at longer time intervals with no compromise in data accuracy. Tipping-bucket precipitation gages are now widely used for most precipitation-data collection and are considered an acceptable instrument by the U.S. Geological Survey.

\section{Quality Assurance of Water-Quality Data}

Quality assurance is a system of activities whose purpose is to produce a product or a service with the assurance that it meets defined standards of quality with a stated level of confidence (Taylor, 1988). Quality assurance is necessary to defend the results of interpretation. All the aspects of the quality-assurance techniques used during this study are discussed below, including the field-instrument quality assurance, the laboratory/fieldanalysis audit programs, the working protocol of quality-assurance procedures provided by the cooperator, and the resulting precision of the collected quality-assurance data. 
Quality assurance has been an integral part of the sampling program since its inception. Table 10 lists the methods of quality assurance used from July 1983 through September 1988. The following discussion briefly explains, in chronological order, the variation in the quality-assurance program during the study.

From August 1983 through January 1985, quality-assurance methods included the U.S. Geological Survey's field-instrument quality-assurance program, seven random samples to assure sample representativeness, and one cooperatorsupplied audit sample. Although, during the beginning of the study, qualityassurance sampling was considered necessary, it was not done on a monthly basis.

Beginning February 1985, quality assurance became part of the monthly sampling program with the issuance of the USEPA Quality Assurance/Quality Control (QA/QC) guidelines contained in a procedural document ("Working Protoco1") for long-term monitoring sites (Aquatic Effects Task Group, 1985). The "Working Protocol" was adhered to until USEPA terminated cooperation in February 1986. Quality-assurance samples submitted to the laboratory for analysis during regular monthly stream sampling accounted for 68 percent of the total number of laboratory analyses from February 1985 until the end of USEPA cooperation.

During the remainder of the 1986 water year and in the 1987 and 1988 water years, quality assurance represented a scaled-down version of the USEPA "Working Protocol". However, quality-assurance samples during this period represented 54 percent of the total laboratory analyses. The U.S. Geological Survey's quality-assurance program of laboratory and field equipment checks remained unaffected by the scaled-down sampling program.

Table 10.--Quality-assurance methods used during the project

[N-National Field Quality Assurance, R-Replicate, C-Container Blank, E-USEPA $\mathrm{L} a b$ and Field Audit, F-Filtration Blank]

\begin{tabular}{|c|c|c|c|c|c|c|}
\hline \multirow[b]{2}{*}{ Month } & \multicolumn{6}{|c|}{ Water Year } \\
\hline & 1983 & 1934 & 1985 & 1986 & 1987 & 1988 \\
\hline October & & & $\mathbf{E}$ & $\mathbf{R}, \mathbf{F}, \mathrm{C}, \mathbf{E}$ & F,C & $\mathbf{R}$ \\
\hline November & & & C & $\mathrm{R}, \mathrm{F}, \mathrm{C}$ & $\mathbf{N}$ & $\mathrm{N}, \mathrm{C}$ \\
\hline December & & & $\mathbf{R}$ & & & $\mathbf{R}$ \\
\hline January & & & & $F, C$ & $\mathbf{F}$ & $\mathbf{R}$ \\
\hline February & & & & $F, C$ & $\mathbf{F}$ & $\mathbf{R}$ \\
\hline March & & & $\mathbf{R}$ & & $\mathbf{R}$ & $\mathrm{C}, \mathrm{N}$ \\
\hline April & & $\mathbf{N}$ & $\mathrm{R}, \mathrm{F}, \mathrm{C}$ & & $\mathrm{C}$ & $\mathbf{F}$ \\
\hline May & & & $\mathrm{F}, \mathrm{C}$ & $\mathbf{R}$ & & $\mathbf{R}$ \\
\hline June & & $\mathrm{c}$ & $R, F, C$ & & $\mathbf{R}$ & \\
\hline July & $\mathbf{N}$ & & $\mathbf{N}$ & $\mathbf{R}$ & C & $\mathrm{C}$ \\
\hline August & & $\mathrm{F}, \mathrm{C}$ & $R, F, C, E$ & $\mathbf{N}$ & & $\mathbf{R}$ \\
\hline September & $\mathbf{R}$ & C & $R, F, C$ & $\mathbf{R}$ & $\mathbf{F}$ & $\mathbf{N}$ \\
\hline
\end{tabular}


The U.S. Geological Survey assesses the validity of data collected in the field through a quality-assurance program that encompasses all water-quality projects. The program was originally named the Biannual Field Quality Assurance program but was later renamed the National Field Quality Assurance (NFQA) program. This nationwide program is done at least annually and the results are reported to U.S. Geological Survey offices that collect such data.

\section{National Field Quality Assurance procedure and results}

Test samples covering a range of values normally found in natural waters are prepared. Two samples for each determination are provided to all those who measure $\mathrm{pH}$ and specific conductance in the field. Results of analyses of each test sample are evaluated statistically to determine the most probable value. Individual determinations are rated against criteria of maximum allowable deviations from the most probable value as satisfactory, marginal, or unsatisfactory. Deviations from the most probable value (MPV) used to determine the ratings are discussed below (D.L. Stanley, U.S. Geological Survey, written commur., 1988). For pH, less than $.11 \mathrm{pH}$ units is satisfactory; greater than .11 but less than $.21 \mathrm{pH}$ units is marginal; greater than .21 units is unsatisfactory. For specific conductance, less than 4 percent is rated satisfactory; greater than 4 percent but less than 6 percent is rated as marginal; and greater than 6 percent is rated as unsatisfactory. For low specific conductances [less that 67 microsiemems per centimeter $(\mu \mathrm{S} / \mathrm{cm})]$, less that $2 \mu \mathrm{S} / \mathrm{cm}$ deviations from the MPV is rated satisfactory; greater than $2 \mu \mathrm{S} / \mathrm{cm}$ but less than $4 \mu \mathrm{S} / \mathrm{cm}$ from the MPV is marginal; and greater than $4 \mu \mathrm{S} / \mathrm{cm}$ deviations from the MPV is unsatisfactory. Alkalinity ratings are defined as follows: Less than 1.5 times the standard deviation from the MPV is rated as satisfactiory. Greater than 1.5 times the standard deviation but less than 2.0 times the standard deviation is rated as marginal. Greater than 2.0 times the standard deviation is rated as unsatisfactory.

A secondary round of testing is done as a follow-up for those participants who report unsatisfactory values. This process helps the principle investigator of a water quality study define the source of error and correct problems.

Field instrumentation and field analytical procedures for this project have been evaluated by the NFQA program eight times between July 1983 and September 1988 (table 10). All eight quality-assurance samples evaluated for both $\mathrm{pH}$ and specific conductance resulted in satisfactory values. One of eight alkalinity values evaluated by NFQA was rated marginal; the other seven were rated satisfactory. 


\section{Laboratory and Field Analysis Audits}

During the cooperation with USEPA, quality-assurance samples submitted to the laboratory on a routine basis amounted to 66 percent of all the samples submitted. Prior to the issuance of the "Working Protocol" and beginning in October 1984, USEPA added an audit sampling program to the quality-assurance plan. This further increased the number of quality-assurance samples by three (table 10).

Audit samples were provided by USEPA through a private contractor. These were spiked samples of known composition used to determine the accuracy of both field and laboratory techniques. Specifically, a 500-mL spiked sample was provided for determining ANC, acidity, specific conductance, and $\mathrm{pH}$, which are measured in the field. An additional 1-L (1iter) aliquot was provided for submission to the laboratory as a regular stream sample. Analytical results were reported to the coordinator of the USEPA long-term monitoring program. However, because the results of these audits were never made available to the principal investigator, all three audits were assumed to have been satisfactory.

\section{"Working Protocol" for Long-Term Monitoring}

In February 1985, the USEPA issued a revised protocol for all projects involved in the long-term surface-water-monitoring program. This protocol specified procedures for the quality-assurance and quality-control program that was to be implemented. During each monthly visit to the study site when a regular streamflow sample was acquired, the following quality-assurance samples were collected and sent to the laboratory:

1) Replicate sample

2) Container blank sample

3) Filtration blank sample

Most of the quality-assurance samples submitted to the laboratory during cooperation with USEPA were those required by this "Working Protocol".

A replicate sample ( $R$ ) was submitted for analysis on a monthly basis. Replicate samples are essentially two complete samples of stream water collected at the same time and point within the stream. Both samples are prepared, packed for shipping, and analyzed identically. The purpose of a replicate sample is to assess the adequacy of the sampling process in obtaining a representative sample of the stream. Beginning with the issuance of the "Working Protocol" through to the end of USEPA cooperation, one replicate sample per month was collected. Before the issuance of the "Working Protocol" and after USEPA cooperation, replicate samples were submitted for analysis randomly (table 10 ).

In addition to a monthly replicate sample, a container blank sample also was submitted for analysis. Container blanks are prepared with unfiltered and unpreserved deionized water. The deionized water was obtained from a water distiller maintained by the United States Corps of Engineers, Pittsburgh, 
Pennsylvania. The purpose of container blank samples was to insure the cleanliness of the sampling containers throughout the project. Nine container blank samples were submitted for analysis beginning with the issuance of the "Working Protocol" through to the end of USEPA cooperation. Six container blank samples were submitted for analysis from March 1986 through September 1988, and three were submitted prior to the issuance of the "Working Protocol" (table 10).

A second set of deionized water samples (filtration blanks) was submitted for monthly analysis. Filtration blank samples were prepared by filtering deionized water through the filtration apparatus containing a membrane typically used for preparing stream water quality samples. This filtered deionized water was poured into the sample bottles and preserved as regular stream water samples. The purpose was to determine the cleanliness of the filtration system and to assure the quality of the filtering membrane. One filtration blank was submitted for analysis prior to the issuance of the "Working Protocol". Nine filtration blanks were submitted for analysis during USEPA cooperation, and five after (table 10).

\section{Precision Observations}

Beginning with the issuance of the USEPA "Working Protocol", all qualityassurance analyses were subject to precision analysis. The "Working Protocol" defined precision as a measure of agreement among individual measurements of the same property, under prescribed similar conditions. Two categories of precision were considered--intralaboratory, and sampling and analysis.

Intralaboratory precision was determined by analyzing individual streamwater samples in duplicate. For this study, duplicate samples were not submitted to the laboratory; however, duplicate analyses were randomly performed on single sample sets by the laboratory. It must be noted that the samples selected for duplicate analyses within the laboratory were not necessarily samples from this study or from any of the other cooperative longterm monitoring studies. Therefore, intralaboratory precision does not directly reflect samples from this study. An unpublished quarterly report was provided by the laboratory showing intralaboratory precision as a result of random duplicate analyses. In general, intralaboratory precision has been good for the period of study.

The combined sampling and analysis precision is estimated from the analysis of the replicate samples collected in the field. Here again, a replicate sample is used to measure the representativeness of the sampling technique.

Replicate precision is determined by taking the difference between two resultant values and multiplying by 0.89 to approximate the standard deviation. The standard deviation divided by the mean of the replicate values and multiplied by 100 yields the relative standard deviation (RSD) in percent. The RSD is an operational statistic indicating the dispersion of a set of replicate measurements as a percentage of the mean value (Taylor, 1988). 
Sample representativeness from data collected from replicates was determined by comparing the RSD with a set of objective precision values provided in the "Working Protocol". The Intralaboratory Relative Precision (IRP) goals, as they are termed by the USEPA, were provided for qualifying the RSD data obtained from duplicate and replicate samples. Here again, no duplicate samples were directly sent from the study site. Therefore, no duplicate RSD-IRP comparisons are listed in this report.

Tables of replicate-precision observations from August 1983 through February 1986 were reported by Barker and Witt III (1990) and are not reproduced in this report. Precision observations for that period, however, reveal that the average RSD values for chloride, phosphate, nitrate, and sulfate were less than the objective precision value. Average RSD values for all other constituents were greater than the IRP goals. Precision observations for quality-assurance replicates collected and analyzed from March 1986 through September 1988 are listed in table 11. Eleven replicates were submitted for analysis during this period and all were compared with the IRP goals. Those constituents covered by the IRP goals are listed in table 11. Sixty-four and 55 percent of the replicate analyses exceeded the IRP goals for base cations and dissolved aluminum, respectively. Less than half of the replicate samples exceeded the IRP goals for fluoride, chloride, phosphate, and sulfate. Nitrate did not exceed the precision objectives for any of the 11 samples. On the basis of the precision analyses, sample representativeness is considered marginal for this period.

Tables of filtration and container blank precision from August 1983 through February 1986 were also reported by Barker and witt III (1990). In summary, filtration blanks confirmed the acceptability of the membrane procedure for dissolved constituents. Although no analytical value was less than its detection limit, nearly all concentrations were within acceptable ranges. Analysis of container blanks similarly confirmed that the containers maintained sample representativeness during shipment and storage.

Five filtration blanks were submitted for analysis during the last two years of study (table 12). Phosphate and aluminum concentrations exceeded the USEPA required lower detection limit in four of five analyses. Iron concentration exceeded the detection limit in two of five analyses. Generally, the filtration apparatus and the filtration membrane did not seem to contaminate the samples.

Results from container blanks analyzed from March 1986 through September 1988 confirmed the cleanliness of the containers. Six container blanks were analyzed during this period. Concentrations of all constituents except phosphate were less than the detection limits for more than half of the analyses. Concentrations of aluminum and manganese were less than the detection limits for all six observations (table 13). In general, results of container blank analyses are satisfactory. 
Table 11.--Results of precision analyses for 11 replicate analyses, March 1986 through September 1988

\begin{tabular}{|c|c|c|c|c|}
\hline Constituent & $\begin{array}{l}\text { Range of } \\
\text { RSD values } 1 \\
\text { (percent) }\end{array}$ & $\begin{array}{c}\text { Average } \\
\text { RSD } \\
\text { (percent) }\end{array}$ & $\operatorname{IRP}^{2}$ & $\begin{array}{l}\text { Number of } \\
\text { replicate } \\
\text { analyses } \\
\text { exceeding } \\
\text { IRP }\end{array}$ \\
\hline $\begin{array}{l}\text { Calcium } \\
\text { Magnesium } \\
\text { Sodium } \\
\text { Potassium } \\
\text { Sulfate } \\
\text { Chloride } \\
\text { Fluoride } \\
\text { Bromide } \\
\text { Silica } \\
\text { Nitrate } \\
\text { Phosphate } \\
\text { Aluminum } \\
\text { Manganese }\end{array}$ & $\begin{aligned} 2.4 & -24 \\
0 & -23 \\
0 & -23 \\
0 & -30 \\
0 & -9.4 \\
0 & -7.1 \\
0 & -16 \\
0 & =17 \\
7.2 & =19.8 \\
0 & =7.1 \\
0 & -92 \\
0 & -30 \\
2.3 & -22\end{aligned}$ & $\begin{array}{r}11.2 \\
10.5 \\
9.7 \\
10.5 \\
1.9 \\
1.4 \\
5.2 \\
1.5 \\
13.8 \\
1.8 \\
12 \\
13.6 \\
7.8\end{array}$ & $\begin{array}{r}5 \\
5 \\
5 \\
5 \\
5 \\
5 \\
5 \\
5 \\
\star \\
10 \\
10 \\
10 \\
10\end{array}$ & $\begin{array}{l}7 \\
7 \\
7 \\
7 \\
2 \\
1 \\
4 \\
1 \\
* \\
0 \\
2 \\
6 \\
3\end{array}$ \\
\hline
\end{tabular}

$1_{\text {RSD }}=$ relative standard deviation

RSD (percent) $=\frac{S D}{\text { MEAN }} \times 100$

${ }^{2}$ IRP = intralaboratory relative precision goal

*No intralaboratory relative precision goal established.

Table 12.--Results of filtration blanks for dissolved constituents in deionized water

[Five observations of each constituent; milligrams per liter except as noted; $\mu \mathrm{s} / \mathrm{cm}$, microsemiens per centimeter at 25 degrees Celsius; $\mu 8 / L$, micrograms per liter; --, no data]

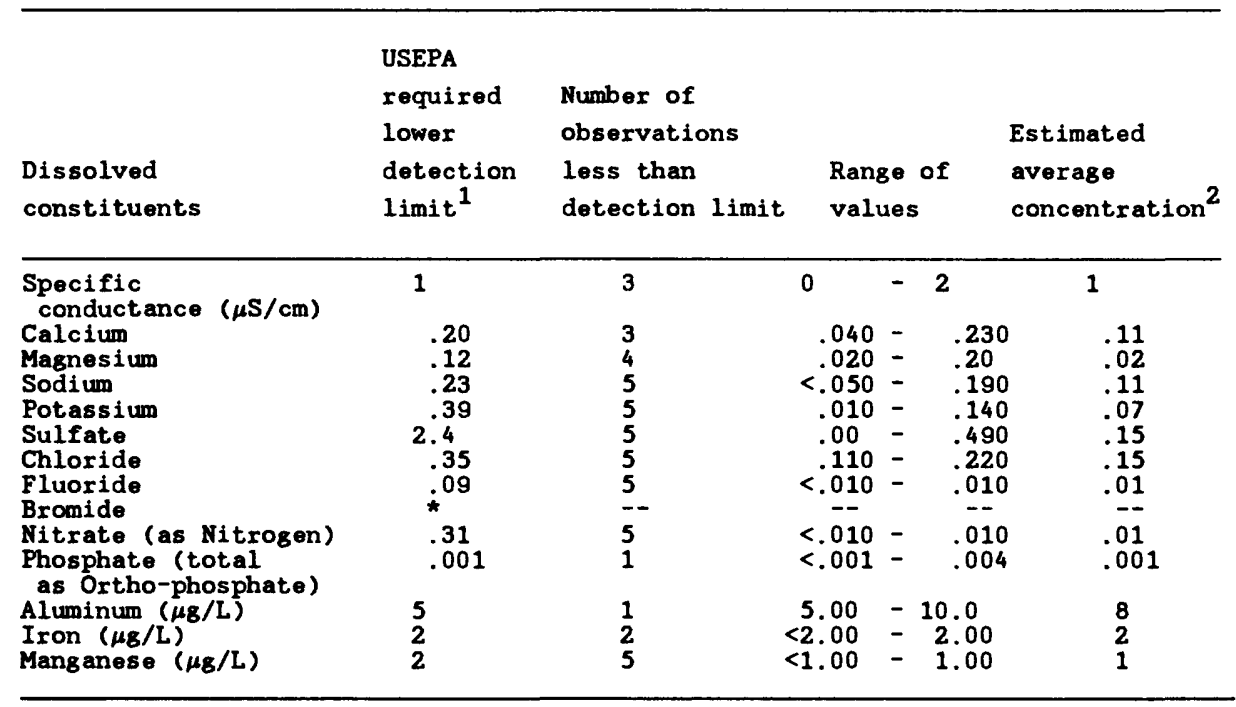

1Adapted from the "Working Protocol" (Aquatic Effects Task Group, 1985 ).

${ }^{2}$ Estimate may be low because of use of a single value for less than.

* No detection limit is specified. 
Table 13.--Results of container blanks for dissolved constituents in deionized water

[Six analyses for each constituent; milligrams per liter except as noted; $\mu \mathrm{g} / \mathrm{L}$, micrograms per liter; $\mu \mathrm{S} / \mathrm{cm}$, microsiemens per centimeter at 25 degrees Celsius; - no data]

\begin{tabular}{|c|c|c|c|c|}
\hline $\begin{array}{l}\text { Dissolved } \\
\text { constituents }\end{array}$ & $\begin{array}{l}\text { USEPA } \\
\text { required } \\
\text { lower } \\
\text { detection } \\
\text { limit }^{1}\end{array}$ & $\begin{array}{l}\text { Number of } \\
\text { observations } \\
\text { less than } \\
\text { detection limit }\end{array}$ & Range & of values \\
\hline $\begin{array}{l}\text { Specific conductance } \\
\text { ( } \mu \text { S/cm) } \\
\text { Acidity as H+ } \\
\text { Calcium } \\
\text { Magnesium } \\
\text { Sodium } \\
\text { Potassium } \\
\text { Sulfate } \\
\text { Chloride } \\
\text { Fluoride } \\
\text { Bromide } \\
\text { Silica } \\
\text { Nitrate (as Nitrogen) } \\
\text { Phosphate (total } \\
\text { as Ortho-phosphate) } \\
\text { Aluminum ( } \mu \mathrm{g} / \mathrm{L}) \\
\text { Iron ( } \mu \mathrm{g} / \mathrm{L}) \\
\text { Manganese ( } \mu \mathrm{g} / \mathrm{L})\end{array}$ & $\begin{array}{l}1 \\
.01 \\
.20 \\
.12 \\
.23 \\
.39 \\
2.4 \\
.35 \\
.09 \\
\star \\
.05 \\
.31 \\
.001 \\
2 \\
2 \\
2\end{array}$ & $\begin{array}{l}3 \\
3 \\
2 \\
4 \\
4 \\
4 \\
4 \\
6 \\
-- \\
3 \\
5 \\
2\end{array}$ & $\begin{array}{l}0 \\
0 \\
.011 \\
.012 \\
<.050 \\
<.010 \\
<.010 \\
<.010 \\
<.010 \\
<.010 \\
0.010 \\
<.010 \\
<.001 \\
<1 \\
<1 \\
<2 \\
<1\end{array}$ & $\begin{array}{l}-2 \\
-.020 \\
1-1.40 \\
2-1.200 \\
0-1.0 \\
0-3.50 \\
0-1.50 \\
0-.050 \\
0-010 \\
0-2.0 \\
-.041 \\
0-1003 \\
1-10 \\
1-10 \\
2-3 \\
1-1\end{array}$ \\
\hline
\end{tabular}

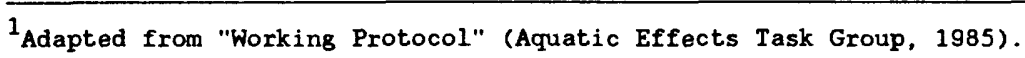

*No detection limit specified.

\section{WATER-RESOURCES DATA}

\section{Water-Quality}

Collection of water-chemistry data began in August 1983 and continued monthly during base-flow conditions through September 1988.

At the time of sample collection, stream discharge also was measured. Figure 14 shows the interquartile ranges for streamflow measurements for water-quality samples during each water year. The median of the streamflow measurements for the 1984 water year was the highest median in the study. The median for the 1985 water year was the lowest. The median streamflow measurement for 1986,87 , and 88 were nearly the same.

Interquartile ranges were also computed for selected major water-quality constituents (fig. 15). These statistics summarize the results of analyses of monthly samples tabulated (tables 14 through 18).

The annual median concentrations of dissolved aluminum and the sum of base-cations ( $\mathrm{Ca}+\mathrm{K}+\mathrm{Na}+\mathrm{Mg}$ ) varied less than the annual medians of the other constituents throughout the study period (fig. 15). Dissolved-aluminum concentrations generally had a narrow range; however, one extreme value was observed in 1984.

Alkalinity varied considerably throughout the study. Negative alkalinities were observed during 1984, 1986, and 1988 (fig. 15). Alkalinity has been shown to vary seasonally (Barker and Witt III, 1990). 


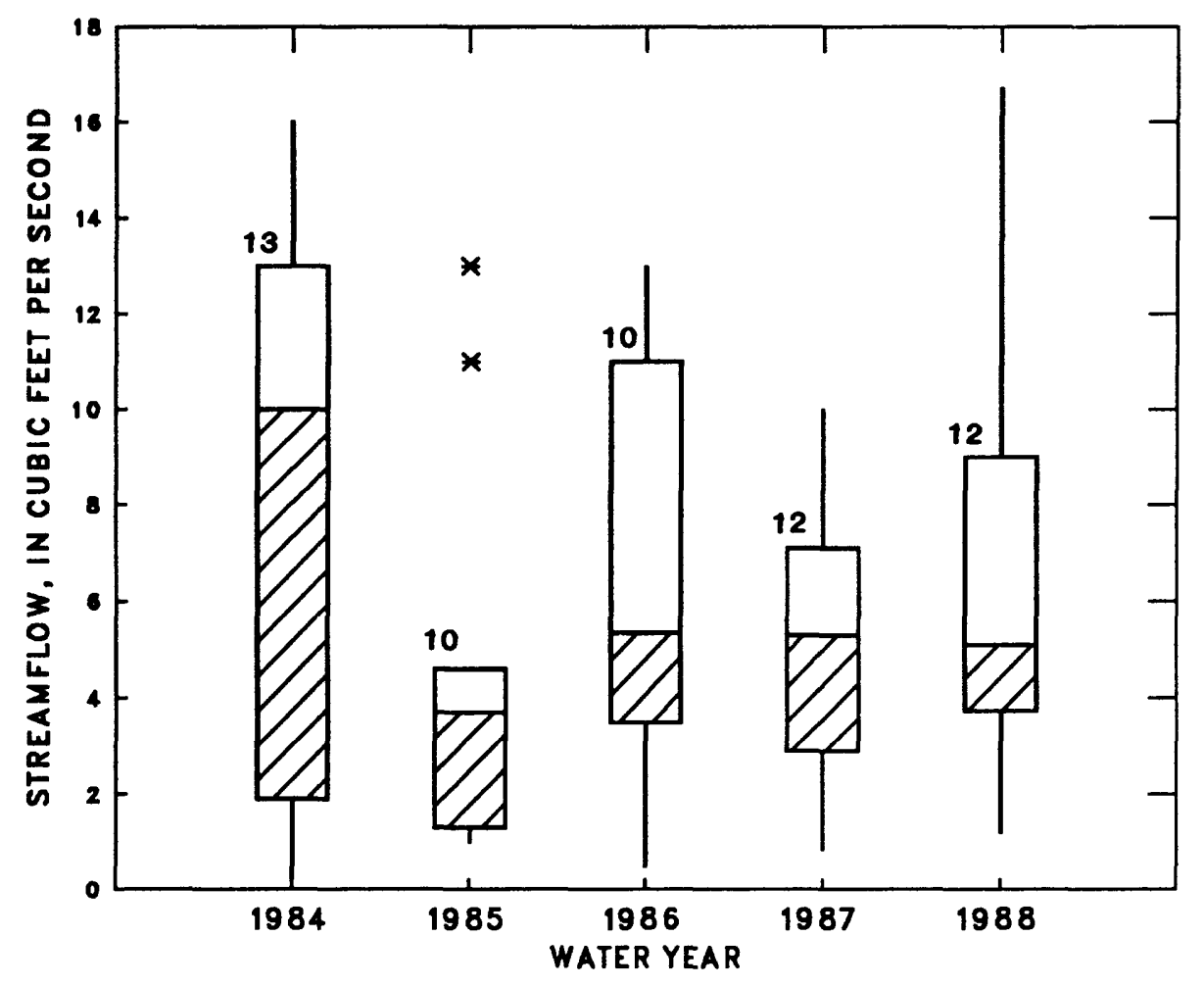

EXPLANATION

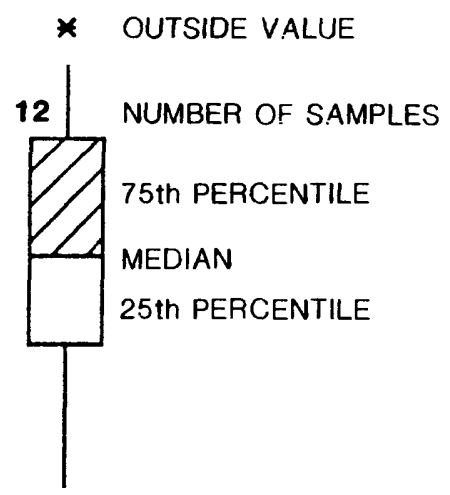

Figure 14.--Median and range of streamflow measurements made when water-quality samples were collected during the 1984 to 1988 water years. 

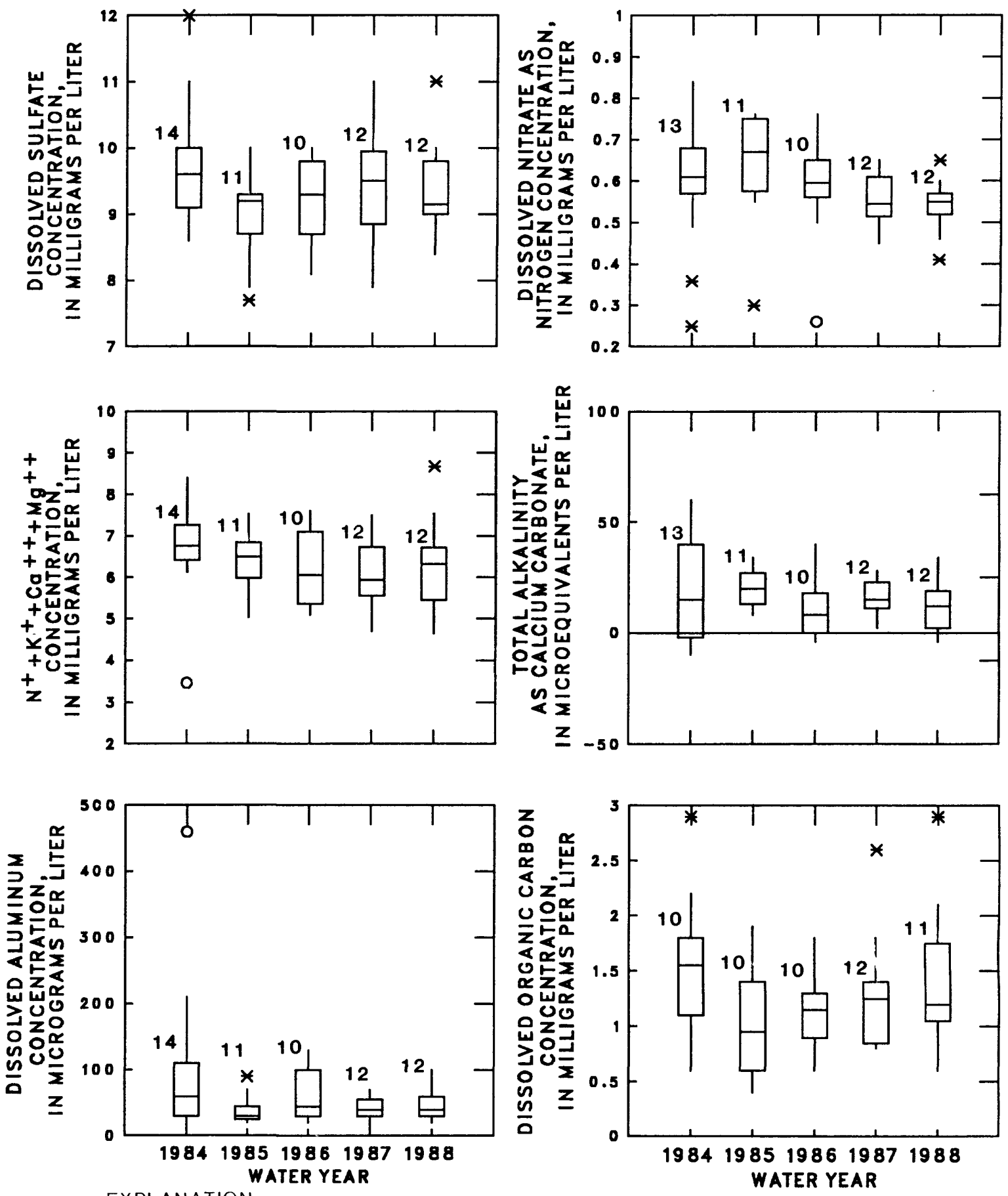

EXPLANATION

- FAR oUtSIDE VALUE

* outside value

12 NUMBER OF SAMPLES

75th PERCENTILE

MEDIAN

25th PERCENTILE

Figure 15.--Annual median and range of concentration for major water-quality contituents for samples collected during 1984 to 1988 for North Fork Bens Creek. 
Table 14.--Water chemistry data for North Fork Bens Croek from August 1983 through September 1984 $\left[\mathrm{ft}^{3} / \mathrm{s}\right.$, cubic feet per second; $\mu \mathrm{S} / \mathrm{cm}$, microsiemens per centimeter at 25 degrees Celsius; 'C degrees Celsius; mg/L, milligrams per liter; $\mu \mathrm{eq} / \mathrm{L}$, microequivalents per liter; $\mu g / L$, micrograms per liter; --, no data]

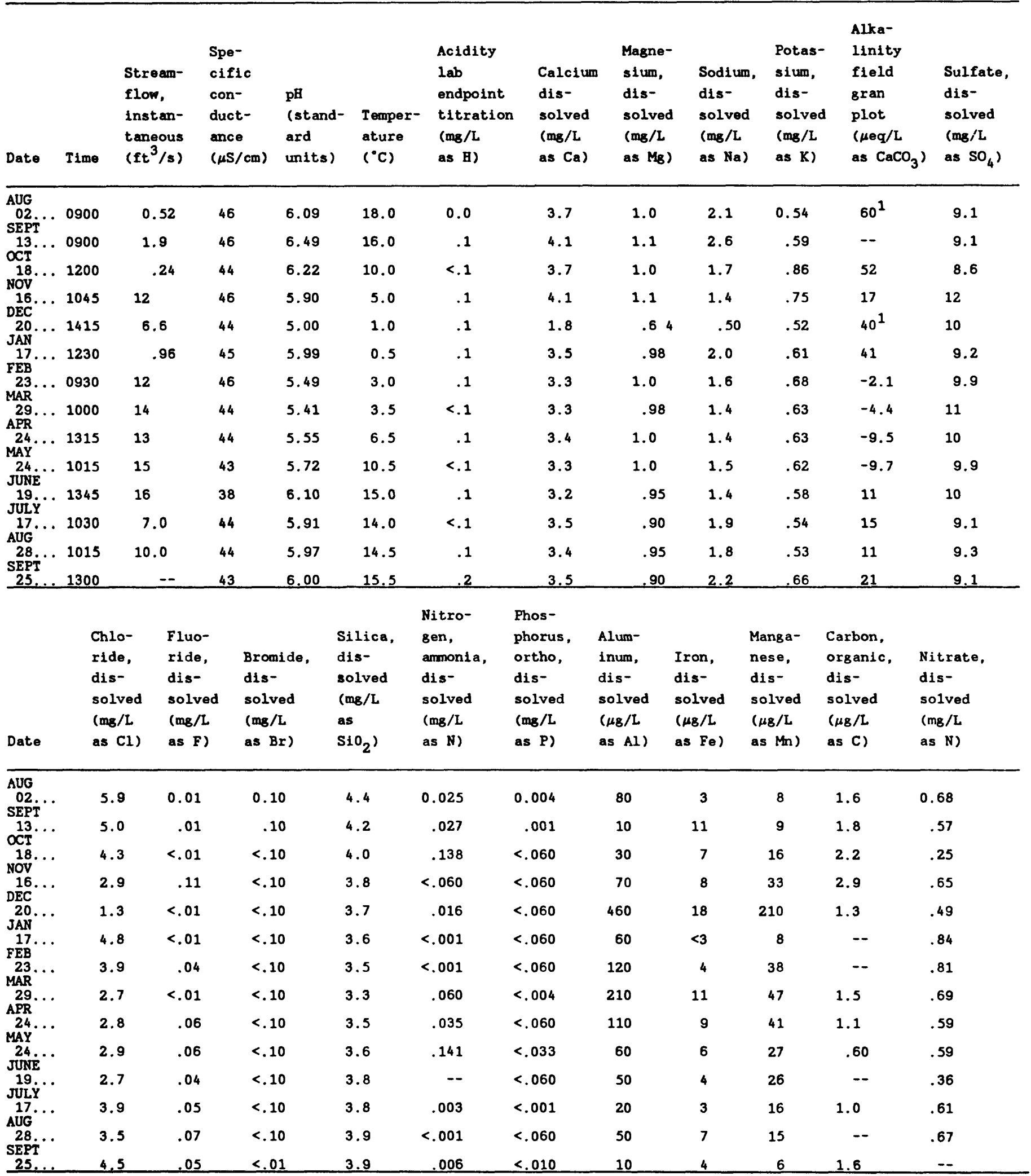

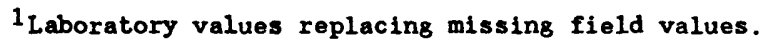


Table 15.--Water chemistry data for North Fork Bens Creek from October 1984 through September 1985 $\left[\mathrm{ft}^{3} / \mathrm{s}\right.$, cubic feet per second; $\mu \mathrm{S} / \mathrm{cm}$, microsiemens per centimeter at 25 degrees Celsius; 'C, degrees Celsius; mg/L, milligrams per liter; $\mu \mathrm{eq} / \mathrm{L}$, microequivalents per liter; $\mu g / L$, micrograms per liter; --, no data]

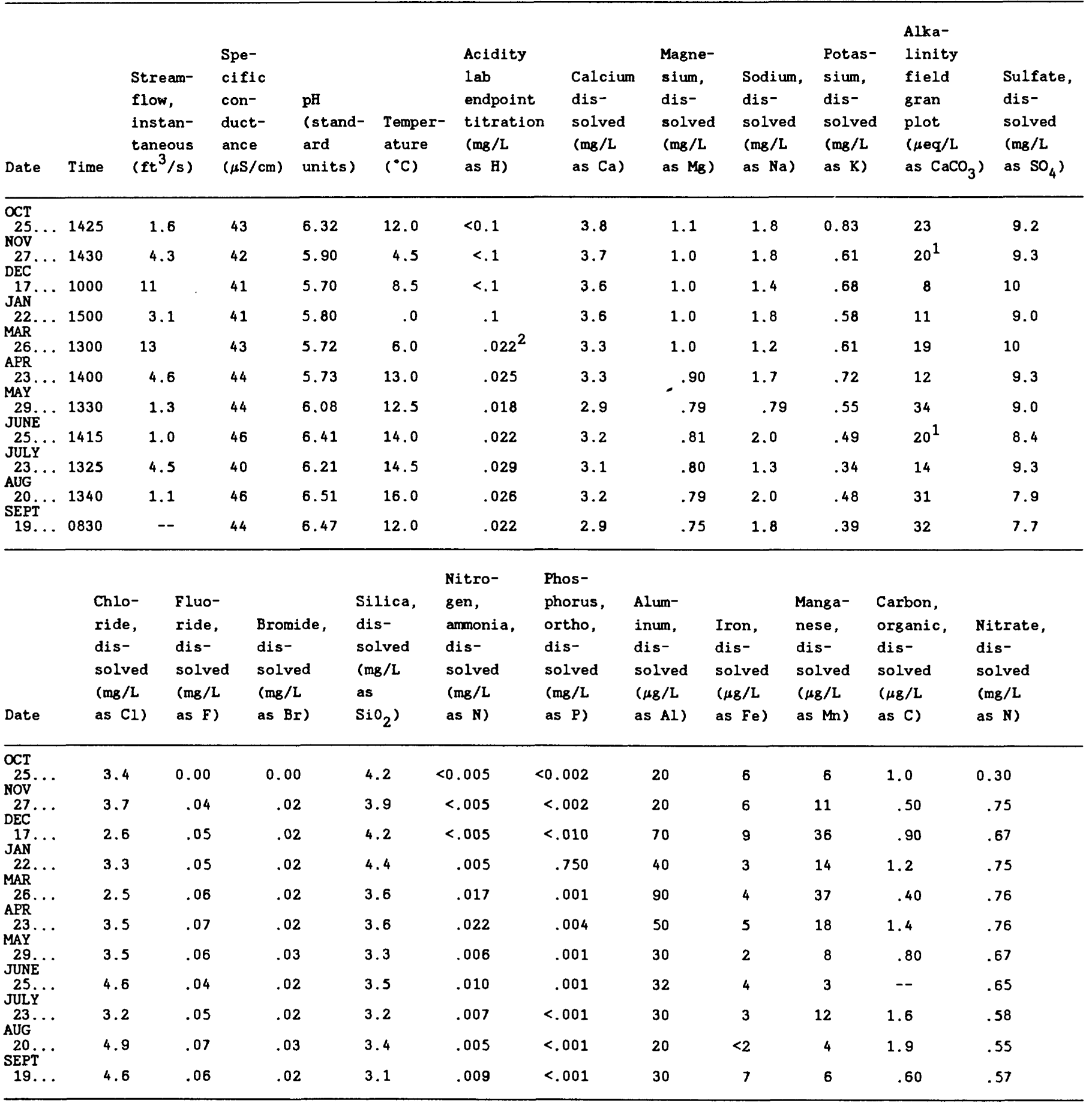

$1_{\text {Laboratory values replacing missing field values. }}$

${ }^{2}$ Second derivative (2ND DVT) method for determining acidity as H+ replaced the endpoint titration method beginning in March 1985. 
Table 16.--Water chemistry data for North Fork Bens Creek from October 1985 through September 1986 $\left[\mathrm{ft}^{3} / \mathrm{s}\right.$, cubic feet per second; $\mu \mathrm{s} / \mathrm{cm}$, microsiemens per centimeter at 25 degrees Celsius; 'C, degrees Celsius; mg/L, milligrams per liter; $\mu$ eq/L, microequivalents per liter; $\mu 8 / L$, micrograms per liter; --, no data]

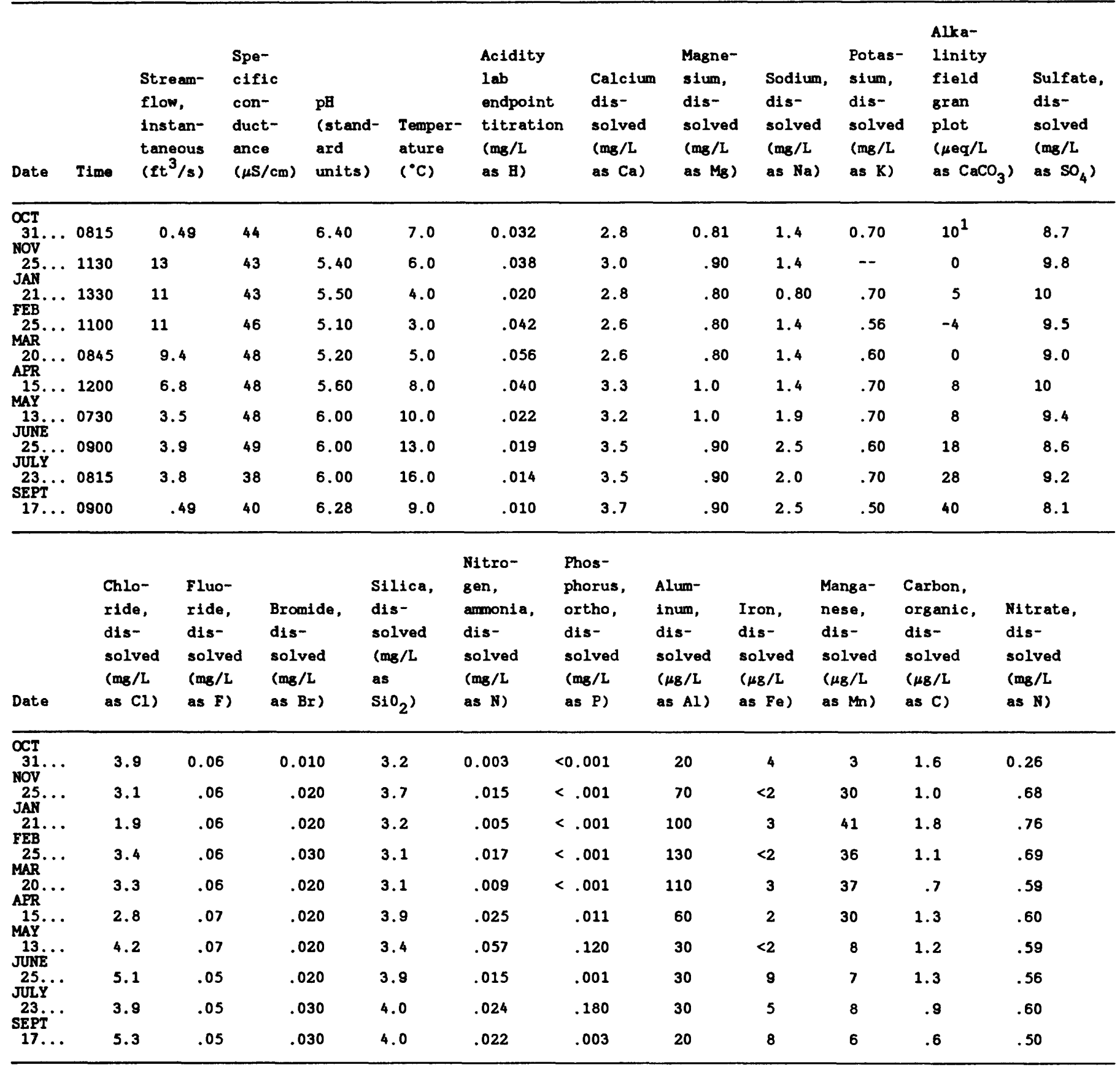

\footnotetext{
${ }^{1}$ Laboratory values replacing missing field values.
} 
Table 17.--Water chemistry data for North Fork Bens Creek from October 1986 through September 1987

$\left[\mathrm{ft}^{3} / \mathrm{s}\right.$, cubic feet per second; $\mu \mathrm{S} / \mathrm{cm}$, microsiemens per centimeter at 25 degrees Celsius; C, degrees Celsius; mg/L, milligrams per liter; $\mu$ eq/L, microequivalents per liter; $\mu \mathrm{g} / \mathrm{L}$, micrograms per liter]

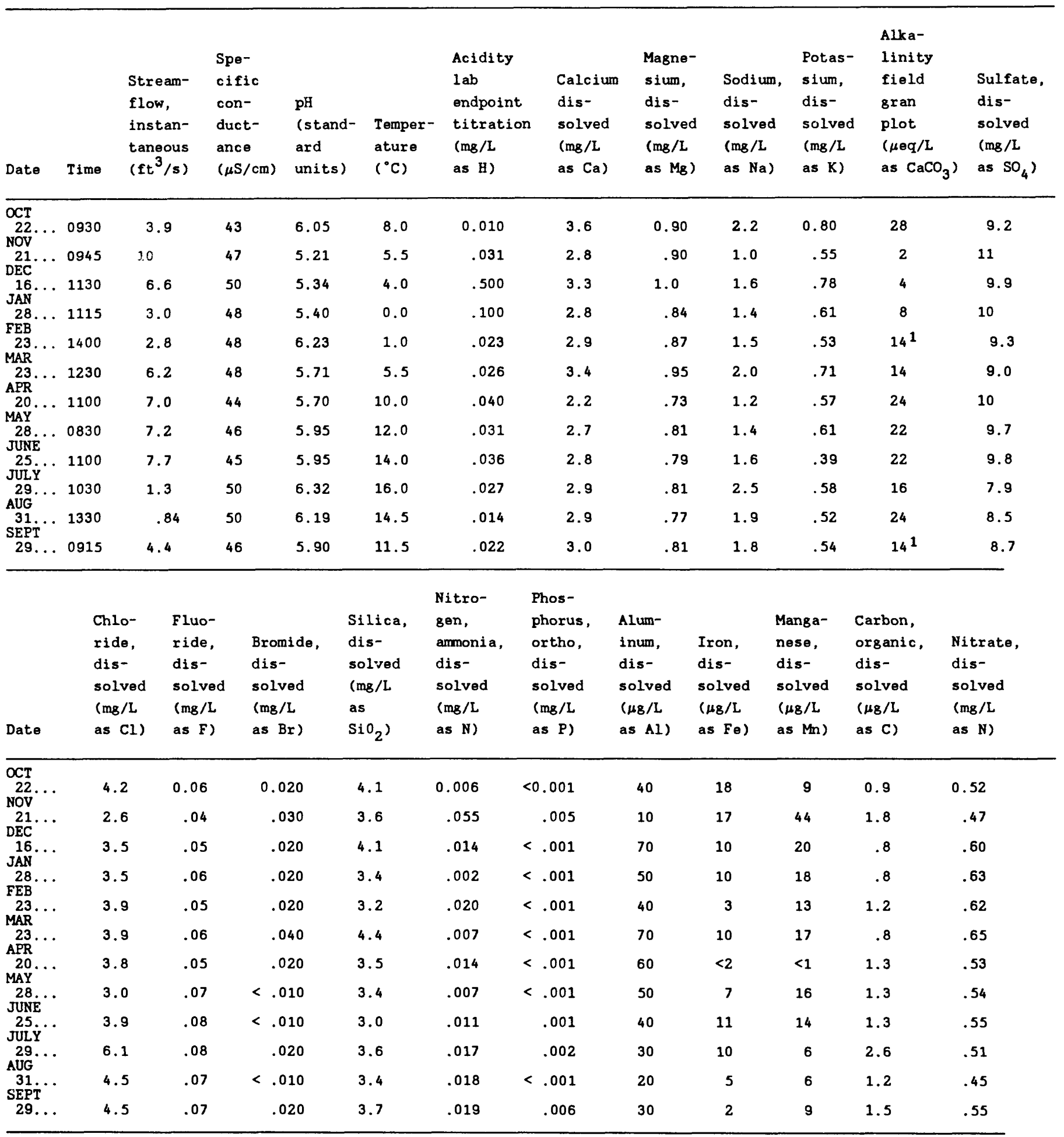

$1_{\text {Laboratory values replacing missing field values. }}$ 
Table 18.--Water chemistry data for North Fork Bens Creek from October 1987 through September 1988

$\left[\mathrm{ft}^{3} / \mathrm{s}\right.$, cubic feet per second; $\mu \mathrm{S} / \mathrm{cm}$, microsiemens per centimeter at 25 degrees Celsius;

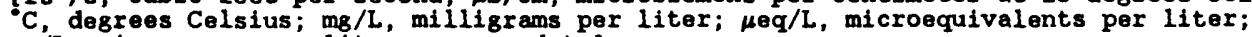
$\mu \mathrm{g} / \mathrm{L}$, micrograms per liter; --, no data]

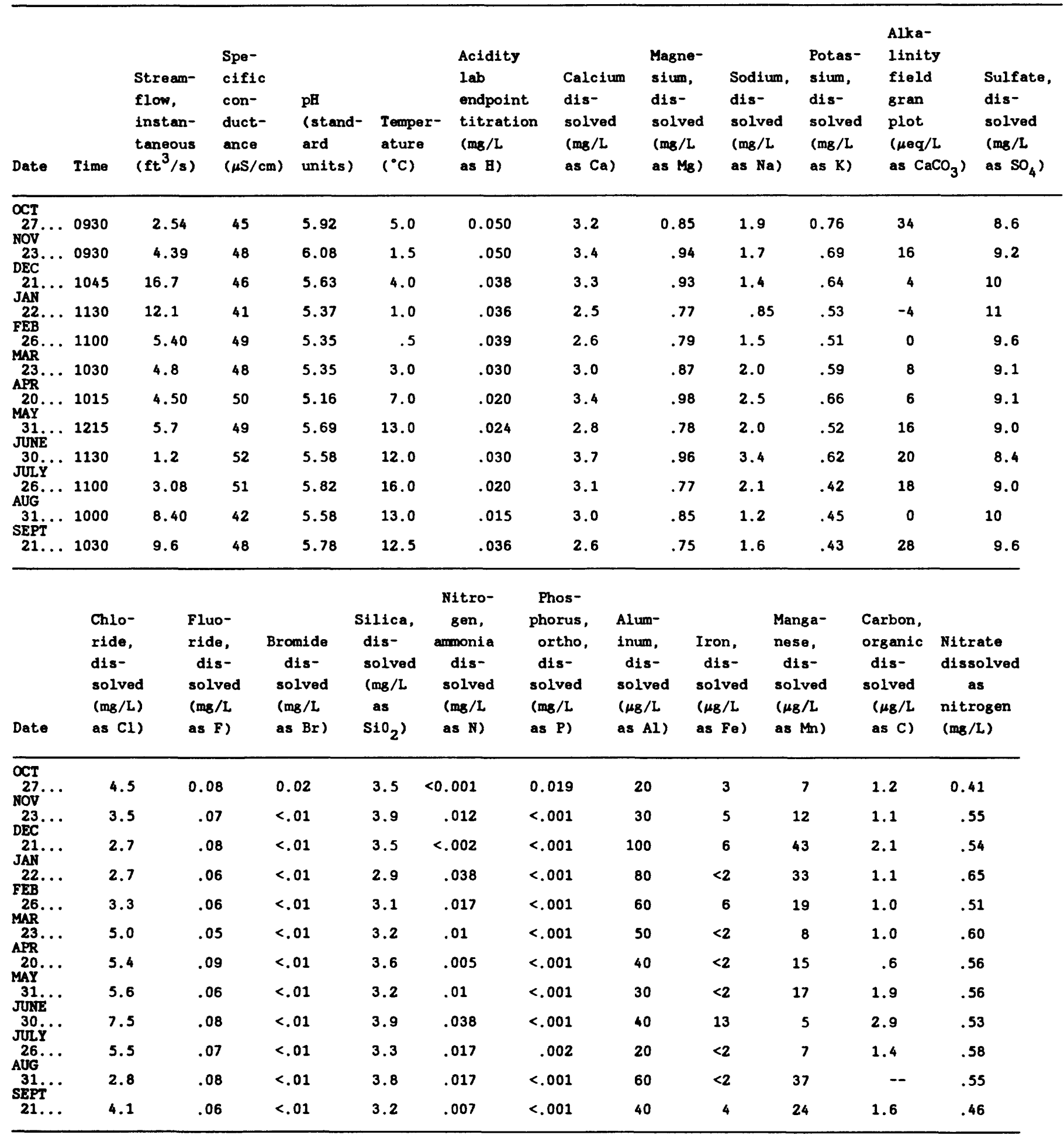




\section{Precipitation}

Precipitation was collected at North Fork Bens Creek from October 1983 through September 1988. Records were compiled, reviewed, and revised annually and entered into the data base of the U.S. Geological Survey, Pittsburgh, Pennsylvania--(Station identification number-03039930). Correction to the record and the computation of missing record were estimated from the NOAA climatological station at Boswe11, Pennsylvania. The data reported here are daily sums in inches (table 19). Hourly values were collected on-site beginning October 1985. Prior to that, digitization of a paper chart would be necessary to generate hourly data. Hourly data are available for the entire period of record for the Boswell climatological station (National Oceanic and Atmospheric Administration, 1983-1988).

Table 19.--Total daily precipitation for North Fork Bens Creek from October 1983 through September 1984 [in inches; --, no data]

\begin{tabular}{|c|c|c|c|c|c|c|c|c|c|c|c|c|}
\hline \multirow[b]{2}{*}{ DAY } & \multicolumn{12}{|c|}{ Water Year 1984} \\
\hline & $\alpha C T$ & NOV & DEC & JAN & FEB & MAR & APR & MAY & JUNE & JULY & AUG & SEPT \\
\hline $\begin{array}{l}1 \\
2 \\
3 \\
4 \\
5\end{array}$ & $\begin{array}{r}0.44 \\
.00 \\
.00 \\
.02 \\
.26\end{array}$ & $\begin{array}{r}0.00 \\
.00 \\
.60 \\
.09 \\
.22\end{array}$ & $\begin{array}{r}0.00 \\
.29 \\
.00 \\
1.14 \\
.03\end{array}$ & $\begin{array}{r}0.00 \\
.00 \\
.00 \\
.00 \\
.02\end{array}$ & $\begin{array}{r}0.00 \\
.00 \\
.10 \\
.08 \\
.03\end{array}$ & $\begin{array}{r}0.00 \\
.00 \\
.00 \\
.00 \\
.83\end{array}$ & $\begin{array}{r}0.00 \\
.00 \\
.20 \\
2.25 \\
.30\end{array}$ & $\begin{array}{r}0.04 \\
.00 \\
.93 \\
.03 \\
.07\end{array}$ & $\begin{array}{r}0.12 \\
.00 \\
.18 \\
.00 \\
.00\end{array}$ & $\begin{array}{r}0.00 \\
.38 \\
.00 \\
.01 \\
.48\end{array}$ & $\begin{array}{r}0.01 \\
.52 \\
.35 \\
1.35 \\
.22\end{array}$ & $\begin{array}{r}0.00 \\
.00 \\
.00 \\
.48 \\
.00\end{array}$ \\
\hline $\begin{array}{r}6 \\
7 \\
8 \\
9 \\
10\end{array}$ & $\begin{array}{l}.00 \\
.00 \\
.00 \\
.05 \\
.00\end{array}$ & $\begin{array}{l}.56 \\
.00 \\
.00 \\
.00 \\
.84\end{array}$ & $\begin{array}{l}.93 \\
.00 \\
.04 \\
.13 \\
.01\end{array}$ & $\begin{array}{l}.07 \\
.32 \\
.10 \\
.00 \\
.30\end{array}$ & $\begin{array}{l}.15 \\
.03 \\
.00 \\
.00 \\
.00\end{array}$ & $\begin{array}{l}.00 \\
.00 \\
.55 \\
.00 \\
.00\end{array}$ & $\begin{array}{l}.40 \\
.10 \\
.00 \\
.00 \\
.00\end{array}$ & $\begin{array}{l}.00 \\
.53 \\
.27 \\
.06 \\
.00\end{array}$ & $\begin{array}{l}.00 \\
.00 \\
.00 \\
.00 \\
.00\end{array}$ & $\begin{array}{l}.32 \\
.00 \\
.00 \\
.00 \\
.65\end{array}$ & $\begin{array}{l}.00 \\
.65 \\
.00 \\
.11 \\
.00\end{array}$ & $\begin{array}{l}.00 \\
.00 \\
.00 \\
.00 \\
.00\end{array}$ \\
\hline $\begin{array}{l}11 \\
12 \\
13 \\
14 \\
15\end{array}$ & $\begin{array}{l}.20 \\
.00 \\
.68 \\
.00 \\
.00\end{array}$ & $\begin{array}{l}.41 \\
.00 \\
.33 \\
.17 \\
.23\end{array}$ & $\begin{array}{l}.01 \\
.40 \\
.11 \\
.00 \\
.10\end{array}$ & $\begin{array}{l}.00 \\
.00 \\
.02 \\
.04 \\
.00\end{array}$ & $\begin{array}{r}.25 \\
.00 \\
.00 \\
1.29 \\
.00\end{array}$ & $\begin{array}{l}.00 \\
.00 \\
.43 \\
.00 \\
.00\end{array}$ & $\begin{array}{l}.00 \\
.00 \\
.08 \\
.67 \\
.16\end{array}$ & $\begin{array}{r}.03 \\
1.13 \\
.30 \\
.00 \\
.00\end{array}$ & $\begin{array}{l}.02 \\
.00 \\
.95 \\
.00 \\
.00\end{array}$ & $\begin{array}{l}.36 \\
.00 \\
.00 \\
.00 \\
.00\end{array}$ & $\begin{array}{r}.49 \\
.81 \\
.77 \\
.35 \\
.00\end{array}$ & $\begin{array}{r}.10 \\
.00 \\
.00 \\
.20 \\
1.03\end{array}$ \\
\hline $\begin{array}{l}16 \\
17 \\
18 \\
19 \\
20\end{array}$ & $\begin{array}{r}.00 \\
.00 \\
1.00 \\
.21 \\
.11\end{array}$ & $\begin{array}{l}.50 \\
.18 \\
.00 \\
.13 \\
.27\end{array}$ & $\begin{array}{l}.08 \\
.00 \\
.00 \\
.02 \\
.00\end{array}$ & $\begin{array}{l}.07 \\
.04 \\
.11 \\
.00 \\
.00\end{array}$ & $\begin{array}{l}.00 \\
.50 \\
.00 \\
.27 \\
.02\end{array}$ & $\begin{array}{l}.00 \\
.00 \\
.00 \\
.00 \\
.01\end{array}$ & $\begin{array}{l}.01 \\
.05 \\
.02 \\
.32 \\
.00\end{array}$ & $\begin{array}{l}.00 \\
.00 \\
.00 \\
.70 \\
.00\end{array}$ & $\begin{array}{r}.00 \\
1.45 \\
1.31 \\
.03 \\
.00\end{array}$ & $\begin{array}{l}.00 \\
.05 \\
.56 \\
.00 \\
.00\end{array}$ & $\begin{array}{l}.00 \\
.00 \\
.00 \\
.30 \\
.00\end{array}$ & $\begin{array}{l}.01 \\
.00 \\
.00 \\
.00 \\
.00\end{array}$ \\
\hline $\begin{array}{l}21 \\
22 \\
23 \\
24 \\
25\end{array}$ & $\begin{array}{l}.00 \\
.15 \\
.76 \\
.03 \\
.22\end{array}$ & $\begin{array}{l}.00 \\
.00 \\
.09 \\
.61 \\
.02\end{array}$ & $\begin{array}{r}.00 \\
1.15 \\
.08 \\
.13 \\
.02\end{array}$ & $\begin{array}{l}.00 \\
.00 \\
.00 \\
.38 \\
.00\end{array}$ & $\begin{array}{l}.02 \\
.00 \\
.20 \\
.01 \\
.53\end{array}$ & $\begin{array}{l}.76 \\
.16 \\
.09 \\
.10 \\
.00\end{array}$ & $\begin{array}{l}.00 \\
.80 \\
.09 \\
.21 \\
.00\end{array}$ & $\begin{array}{l}.30 \\
.00 \\
.20 \\
.00 \\
.00\end{array}$ & $\begin{array}{r}.00 \\
.00 \\
.00 \\
1.28 \\
.00\end{array}$ & $\begin{array}{r}.00 \\
.00 \\
.00 \\
1.28 \\
.00\end{array}$ & $\begin{array}{l}.00 \\
.62 \\
.00 \\
.00 \\
.00\end{array}$ & $\begin{array}{l}.00 \\
.00 \\
.00 \\
.01 \\
.00\end{array}$ \\
\hline $\begin{array}{l}26 \\
27 \\
28 \\
29 \\
30 \\
31\end{array}$ & $\begin{array}{l}.00 \\
.00 \\
.00 \\
.00 \\
.00 \\
.00\end{array}$ & $\begin{array}{r}.00 \\
.00 \\
1.03 \\
.00 \\
.00 \\
--\end{array}$ & $\begin{array}{l}.00 \\
.00 \\
.63 \\
.00 \\
.02 \\
.00\end{array}$ & $\begin{array}{l}.00 \\
.03 \\
.00 \\
.26 \\
.51 \\
.00\end{array}$ & $\begin{array}{l}.00 \\
.00 \\
.55 \\
.19 \\
-- \\
--\end{array}$ & $\begin{array}{l}.00 \\
.10 \\
.72 \\
.49 \\
.11 \\
.00\end{array}$ & $\begin{array}{l}.00 \\
.00 \\
.58 \\
.00 \\
.01 \\
.-\end{array}$ & $\begin{array}{r}.05 \\
.00 \\
1.50 \\
.04 \\
.00 \\
.00\end{array}$ & $\begin{array}{l}.00 \\
.06 \\
.00 \\
.35 \\
.65 \\
--\end{array}$ & $\begin{array}{l}.05 \\
.05 \\
.00 \\
.00 \\
.00 \\
.00\end{array}$ & $\begin{array}{l}.00 \\
.00 \\
.00 \\
.00 \\
.30 \\
.00\end{array}$ & $\begin{array}{l}.20 \\
.00 \\
.14 \\
.00 \\
.00 \\
--\end{array}$ \\
\hline Total & 4.13 & 6.28 & 5.32 & 2.27 & 4.22 & 4.35 & 6.25 & 6.18 & 6.40 & 4.19 & 6.85 & 2.17 \\
\hline Water & ar 1984 & Total & 58.61 & & & & & & & & & \\
\hline
\end{tabular}


Table 19.--Total dally precipitation for North Fork Bens Creek from October 1983 through September 1988--Continued [in inches; --, no data]

\begin{tabular}{|c|c|c|c|c|c|c|c|c|c|c|c|c|}
\hline \multirow[b]{2}{*}{ DAY } & \multicolumn{12}{|c|}{ Water Year 1985} \\
\hline & oCT & NOV & DEC & JAN & FEB & MAR & APR & MAY & JUNE & JULY & AUG & SEPT \\
\hline $\begin{array}{l}1 \\
2 \\
3 \\
4 \\
5\end{array}$ & $\begin{array}{r}0.62 \\
.00 \\
.00 \\
.00 \\
.00\end{array}$ & $\begin{array}{r}0.00 \\
.38 \\
.00 \\
1.14 \\
.00\end{array}$ & $\begin{array}{r}0.42 \\
.00 \\
.37 \\
.00 \\
.00\end{array}$ & $\begin{array}{r}0.09 \\
.00 \\
.00 \\
.09 \\
.15\end{array}$ & $\begin{array}{r}0.35 \\
.30 \\
.02 \\
.00 \\
.21\end{array}$ & $\begin{array}{r}0.00 \\
.00 \\
.00 \\
.00 \\
.60\end{array}$ & $\begin{array}{r}0.10 \\
.01 \\
.25 \\
.12 \\
.00\end{array}$ & $\begin{array}{r}0.00 \\
2.23 \\
.00 \\
.00 \\
.00\end{array}$ & $\begin{array}{r}0.00 \\
.00 \\
.02 \\
.00 \\
.19\end{array}$ & $\begin{array}{r}0.14 \\
.00 \\
.96 \\
.00 \\
.05\end{array}$ & $\begin{array}{r}0.00 \\
.00 \\
.00 \\
.00 \\
.00\end{array}$ & $\begin{array}{r}0.00 \\
.00 \\
.00 \\
.00 \\
.00\end{array}$ \\
\hline $\begin{array}{r}6 \\
7 \\
8 \\
9 \\
10\end{array}$ & $\begin{array}{l}.00 \\
.00 \\
.18 \\
.07 \\
.00\end{array}$ & $\begin{array}{l}.00 \\
.00 \\
.00 \\
.30 \\
.25\end{array}$ & $\begin{array}{l}.63 \\
.00 \\
.00 \\
.00 \\
.00\end{array}$ & $\begin{array}{l}.00 \\
.33 \\
.10 \\
.00 \\
.00\end{array}$ & $\begin{array}{l}.15 \\
.02 \\
.00 \\
.00 \\
.00\end{array}$ & $\begin{array}{l}.00 \\
.05 \\
.31 \\
.00 \\
.00\end{array}$ & $\begin{array}{l}.02 \\
.42 \\
.05 \\
.38 \\
.00\end{array}$ & $\begin{array}{l}.26 \\
.00 \\
.00 \\
.00 \\
.00\end{array}$ & $\begin{array}{l}.00 \\
.00 \\
.00 \\
.00 \\
.00\end{array}$ & $\begin{array}{r}.00 \\
.00 \\
.07 \\
.94 \\
.23\end{array}$ & $\begin{array}{l}.00 \\
.30 \\
.00 \\
.00 \\
.00\end{array}$ & $\begin{array}{l}.00 \\
.26 \\
.06 \\
.11 \\
.00\end{array}$ \\
\hline $\begin{array}{l}11 \\
12 \\
13 \\
14 \\
15\end{array}$ & $\begin{array}{l}.00 \\
.00 \\
.00 \\
.00 \\
.00\end{array}$ & $\begin{array}{l}.03 \\
.00 \\
.00 \\
.00 \\
.05\end{array}$ & $\begin{array}{l}.13 \\
.00 \\
.00 \\
.40 \\
.00\end{array}$ & $\begin{array}{l}.20 \\
.05 \\
.00 \\
.25 \\
.00\end{array}$ & $\begin{array}{l}.02 \\
.55 \\
.05 \\
.09 \\
.05\end{array}$ & $\begin{array}{r}.00 \\
1.09 \\
.00 \\
.06 \\
.00\end{array}$ & $\begin{array}{l}.34 \\
.00 \\
.02 \\
.01 \\
.00\end{array}$ & $\begin{array}{r}.00 \\
.00 \\
.10 \\
.00 \\
.05\end{array}$ & $\begin{array}{l}.00 \\
.45 \\
.10 \\
.04 \\
.13\end{array}$ & $\begin{array}{r}.06 \\
.25 \\
.00 \\
.00 \\
.00\end{array}$ & $\begin{array}{l}.00 \\
.00 \\
.00 \\
.00 \\
.36\end{array}$ & $\begin{array}{l}.00 \\
.00 \\
.00 \\
.00 \\
.00\end{array}$ \\
\hline $\begin{array}{l}16 \\
17 \\
18 \\
19 \\
20\end{array}$ & $\begin{array}{l}.00 \\
.29 \\
.00 \\
.13 \\
.00\end{array}$ & $\begin{array}{l}.00 \\
.00 \\
.30 \\
.00 \\
.00\end{array}$ & $\begin{array}{l}.00 \\
.00 \\
.00 \\
.84 \\
.00\end{array}$ & $\begin{array}{l}.00 \\
.34 \\
.17 \\
.17 \\
.04\end{array}$ & $\begin{array}{l}.00 \\
.00 \\
.00 \\
.00 \\
.00\end{array}$ & $\begin{array}{l}.00 \\
.08 \\
.04 \\
.00 \\
.50\end{array}$ & $\begin{array}{l}.10 \\
.00 \\
.00 \\
.00 \\
.00\end{array}$ & $\begin{array}{l}.03 \\
.92 \\
.08 \\
.00 \\
.00\end{array}$ & $\begin{array}{l}.24 \\
.08 \\
.00 \\
.02 \\
.15\end{array}$ & $\begin{array}{l}.00 \\
.02 \\
.00 \\
.00 \\
.02\end{array}$ & $\begin{array}{l}.23 \\
.00 \\
.00 \\
.00 \\
.03\end{array}$ & $\begin{array}{l}.00 \\
.00 \\
.00 \\
.00 \\
.00\end{array}$ \\
\hline $\begin{array}{l}21 \\
22 \\
23 \\
24 \\
25\end{array}$ & $\begin{array}{l}.01 \\
.55 \\
.17 \\
.02 \\
.07\end{array}$ & $\begin{array}{l}.00 \\
.00 \\
.00 \\
.00 \\
.00\end{array}$ & $\begin{array}{l}.82 \\
.00 \\
.00 \\
.38 \\
.00\end{array}$ & $\begin{array}{l}.00 \\
.00 \\
.00 \\
.04 \\
.20\end{array}$ & $\begin{array}{l}.00 \\
.06 \\
.00 \\
.01 \\
.00\end{array}$ & $\begin{array}{l}.00 \\
.23 \\
.74 \\
.88 \\
.00\end{array}$ & $\begin{array}{l}.00 \\
.00 \\
.07 \\
.07 \\
.08\end{array}$ & $\begin{array}{l}.00 \\
.00 \\
.33 \\
.00 \\
.00\end{array}$ & $\begin{array}{l}.00 \\
.70 \\
.00 \\
.00 \\
.00\end{array}$ & $\begin{array}{r}.00 \\
1.97 \\
.00 \\
.00 \\
.20\end{array}$ & $\begin{array}{l}.00 \\
.00 \\
.00 \\
.52 \\
.55\end{array}$ & $\begin{array}{l}.00 \\
.00 \\
.00 \\
.23 \\
.00\end{array}$ \\
\hline $\begin{array}{l}26 \\
27 \\
28 \\
29 \\
30 \\
31\end{array}$ & $\begin{array}{l}.00 \\
.00 \\
.00 \\
.37 \\
.00 \\
.00\end{array}$ & $\begin{array}{r}.00 \\
.00 \\
1.00 \\
.00 \\
.00 \\
-0\end{array}$ & $\begin{array}{l}.01 \\
.00 \\
.04 \\
.00 \\
.70 \\
.02\end{array}$ & $\begin{array}{l}.23 \\
.00 \\
.03 \\
.00 \\
.00 \\
.28\end{array}$ & $\begin{array}{l}.05 \\
.17 \\
.00 \\
- \\
- \\
.-\end{array}$ & $\begin{array}{r}.00 \\
.00 \\
.17 \\
1.13 \\
1.05 \\
.99\end{array}$ & $\begin{array}{l}.00 \\
.00 \\
.00 \\
.00 \\
.00 \\
--\end{array}$ & $\begin{array}{l}.00 \\
.00 \\
.70 \\
.00 \\
.00 \\
.52\end{array}$ & $\begin{array}{l}.00 \\
.00 \\
.00 \\
.04 \\
.00 \\
.0\end{array}$ & $\begin{array}{l}.72 \\
.00 \\
.00 \\
.00 \\
.00 \\
.05\end{array}$ & $\begin{array}{l}.00 \\
.00 \\
.00 \\
.00 \\
.24 \\
.03\end{array}$ & $\begin{array}{l}.00 \\
.01 \\
.00 \\
.00 \\
.00 \\
.\end{array}$ \\
\hline Total & 2.48 & 3.45 & 4.76 & 2.76 & 2.10 & 7.92 & 2.04 & 5.22 & 2.16 & 5.68 & 2.26 & 0.67 \\
\hline \multicolumn{13}{|c|}{$\begin{array}{l}\text { Calendar Year } 1984 \text { Total } 53.57 \\
\text { Water Year } 1985 \text { Total } 1.50\end{array}$} \\
\hline
\end{tabular}


Table 19.--Total daily precipitation for North Fork Bens Creek from October 1983 through September 1988--Continued [in inches; --, no data]

\begin{tabular}{|c|c|c|c|c|c|c|c|c|c|c|c|c|}
\hline \multirow[b]{2}{*}{ DAY } & \multicolumn{12}{|c|}{ Water Year 1986} \\
\hline & OCT & NOV & DEC & JAN & FEB & MAR & APR & MAY & JUNE & JULY & AUG & SEPT \\
\hline $\begin{array}{l}1 \\
2 \\
3 \\
4 \\
5\end{array}$ & $\begin{array}{r}0.31 \\
.01 \\
.00 \\
.05 \\
.01\end{array}$ & $\begin{array}{r}0.02 \\
.15 \\
.33 \\
.29 \\
.26\end{array}$ & $\begin{array}{r}0.04 \\
.13 \\
.00 \\
.00 \\
.00\end{array}$ & $\begin{array}{r}0.00 \\
.00 \\
.11 \\
.00 \\
.11\end{array}$ & $\begin{array}{r}0.04 \\
.05 \\
.00 \\
1.25 \\
.81\end{array}$ & $\begin{array}{r}0.00 \\
.00 \\
.01 \\
.01 \\
.00\end{array}$ & $\begin{array}{r}0.00 \\
.00 \\
.00 \\
.00 \\
.01\end{array}$ & $\begin{array}{r}0.00 \\
.03 \\
.00 \\
.00 \\
.00\end{array}$ & $\begin{array}{r}0.00 \\
.03 \\
.00 \\
.00 \\
.10\end{array}$ & $\begin{array}{r}0.14 \\
.45 \\
.00 \\
.00 \\
.00\end{array}$ & $\begin{array}{r}0.00 \\
.06 \\
.00 \\
.00 \\
.00\end{array}$ & $\begin{array}{r}0.00 \\
.00 \\
.00 \\
.01 \\
.27\end{array}$ \\
\hline $\begin{array}{r}6 \\
7 \\
8 \\
9 \\
10\end{array}$ & $\begin{array}{l}.02 \\
.00 \\
.00 \\
.00 \\
.08\end{array}$ & $\begin{array}{l}.14 \\
.06 \\
.00 \\
.06 \\
.25\end{array}$ & $\begin{array}{l}.35 \\
.00 \\
.00 \\
.00 \\
.14\end{array}$ & $\begin{array}{l}.00 \\
.00 \\
.00 \\
.00 \\
.00\end{array}$ & $\begin{array}{l}.29 \\
.32 \\
.01 \\
.00 \\
.04\end{array}$ & $\begin{array}{l}.18 \\
.10 \\
.00 \\
.00 \\
.38\end{array}$ & $\begin{array}{l}.15 \\
.05 \\
.02 \\
.00 \\
.04\end{array}$ & $\begin{array}{l}.00 \\
.16 \\
.00 \\
.00 \\
.00\end{array}$ & $\begin{array}{l}.43 \\
.13 \\
.22 \\
.01 \\
.00\end{array}$ & $\begin{array}{r}.00 \\
.23 \\
.13 \\
1.97 \\
.00\end{array}$ & $\begin{array}{l}.17 \\
.51 \\
.06 \\
.57 \\
.13\end{array}$ & $\begin{array}{l}.00 \\
.02 \\
.00 \\
.00 \\
.00\end{array}$ \\
\hline $\begin{array}{l}11 \\
12 \\
13 \\
14 \\
15\end{array}$ & $\begin{array}{l}.09 \\
.00 \\
.06 \\
.18 \\
.06\end{array}$ & $\begin{array}{l}.09 \\
.33 \\
.06 \\
.09 \\
.11\end{array}$ & $\begin{array}{l}.59 \\
.12 \\
.39 \\
.00 \\
.00\end{array}$ & $\begin{array}{l}.00 \\
.00 \\
.06 \\
.00 \\
.00\end{array}$ & $\begin{array}{l}.25 \\
.00 \\
.01 \\
.08 \\
.01\end{array}$ & $\begin{array}{r}.14 \\
.09 \\
.48 \\
1.23 \\
.28\end{array}$ & $\begin{array}{l}.18 \\
.00 \\
.07 \\
.02 \\
.02\end{array}$ & $\begin{array}{l}.00 \\
.00 \\
.01 \\
.74 \\
.00\end{array}$ & $\begin{array}{l}.41 \\
.24 \\
.01 \\
.00 \\
.00\end{array}$ & $\begin{array}{l}.32 \\
.22 \\
.70 \\
.00 \\
.00\end{array}$ & $\begin{array}{l}.41 \\
.00 \\
.00 \\
.00 \\
.15\end{array}$ & $\begin{array}{l}.00 \\
.20 \\
.00 \\
.00 \\
.01\end{array}$ \\
\hline $\begin{array}{l}16 \\
17 \\
18 \\
19 \\
20\end{array}$ & $\begin{array}{l}.00 \\
.00 \\
.00 \\
.13 \\
.15\end{array}$ & $\begin{array}{l}.31 \\
.24 \\
.00 \\
.00 \\
.00\end{array}$ & $\begin{array}{l}.05 \\
.03 \\
.00 \\
.00 \\
.01\end{array}$ & $\begin{array}{r}.00 \\
.00 \\
.01 \\
.62 \\
2.11\end{array}$ & $\begin{array}{l}.02 \\
.35 \\
.14 \\
.43 \\
.00\end{array}$ & $\begin{array}{r}.00 \\
.00 \\
.00 \\
1.28 \\
.00\end{array}$ & $\begin{array}{l}.41 \\
.13 \\
.00 \\
.00 \\
.00\end{array}$ & $\begin{array}{l}.00 \\
.00 \\
.92 \\
.34 \\
.34\end{array}$ & $\begin{array}{l}.28 \\
.02 \\
.00 \\
.00 \\
.57\end{array}$ & $\begin{array}{r}.01 \\
.11 \\
.00 \\
.45 \\
1.03\end{array}$ & $\begin{array}{l}.14 \\
.04 \\
.00 \\
.00 \\
.00\end{array}$ & $\begin{array}{l}.03 \\
.00 \\
.35 \\
.06 \\
.00\end{array}$ \\
\hline $\begin{array}{l}21 \\
22 \\
23 \\
24 \\
25\end{array}$ & $\begin{array}{r}.19 \\
.20 \\
.01 \\
.32 \\
.00\end{array}$ & $\begin{array}{l}.00 \\
.14 \\
.00 \\
.00 \\
.12\end{array}$ & $\begin{array}{l}.01 \\
.00 \\
.09 \\
.03 \\
.00\end{array}$ & $\begin{array}{l}.00 \\
.03 \\
.00 \\
.00 \\
.00\end{array}$ & $\begin{array}{l}.35 \\
.13 \\
.00 \\
.04 \\
.00\end{array}$ & $\begin{array}{l}.00 \\
.00 \\
.00 \\
.00 \\
.00\end{array}$ & $\begin{array}{l}.13 \\
.00 \\
.00 \\
.00 \\
.00\end{array}$ & $\begin{array}{l}.11 \\
.00 \\
.18 \\
.00 \\
.00\end{array}$ & $\begin{array}{l}.00 \\
.00 \\
.12 \\
.00 \\
.00\end{array}$ & $\begin{array}{l}.00 \\
.00 \\
.00 \\
.02 \\
.42\end{array}$ & $\begin{array}{l}.21 \\
.00 \\
.20 \\
.00 \\
.00\end{array}$ & $\begin{array}{l}.00 \\
.01 \\
.39 \\
.31 \\
.46\end{array}$ \\
\hline $\begin{array}{l}26 \\
27 \\
28 \\
29 \\
30 \\
31\end{array}$ & $\begin{array}{l}.00 \\
.00 \\
.00 \\
.00 \\
.06 \\
.01\end{array}$ & $\begin{array}{l}.35 \\
.57 \\
.92 \\
.01 \\
.00 \\
--\end{array}$ & $\begin{array}{l}.00 \\
.01 \\
.01 \\
.00 \\
.00 \\
.00\end{array}$ & $\begin{array}{l}.02 \\
.09 \\
.00 \\
.00 \\
.02 \\
.05\end{array}$ & $\begin{array}{l}.00 \\
.00 \\
.00 \\
-- \\
-- \\
--\end{array}$ & $\begin{array}{l}.00 \\
.00 \\
.00 \\
.00 \\
.00 \\
.00\end{array}$ & $\begin{array}{l}.00 \\
.00 \\
.00 \\
.00 \\
.00 \\
--\end{array}$ & $\begin{array}{l}.00 \\
.97 \\
.01 \\
.00 \\
.16 \\
.01\end{array}$ & $\begin{array}{l}.00 \\
.19 \\
.10 \\
.00 \\
.08 \\
--\end{array}$ & $\begin{array}{l}.01 \\
.00 \\
.00 \\
.10 \\
.06 \\
.00\end{array}$ & $\begin{array}{l}.00 \\
.11 \\
.06 \\
.00 \\
.00 \\
.00\end{array}$ & $\begin{array}{l}.00 \\
.03 \\
.01 \\
.00 \\
.15 \\
--\end{array}$ \\
\hline Total & 1.94 & 4.90 & 2.00 & 3.23 & 4.62 & 4.18 & 1.23 & 3.98 & 2.94 & 6.37 & 2.82 & 2.31 \\
\hline \multicolumn{13}{|c|}{$\begin{array}{l}\text { Calendar Year } 1985 \text { Total } 39.65 \\
\text { Water Year } 1986 \text { Total } 40.52\end{array}$} \\
\hline
\end{tabular}


Table 19.--Total daily precipitation for North Fork Bens Creek from October 1983 through September $1988--C o n t i n u e d$ [in inches; --, no data]

\begin{tabular}{|c|c|c|c|c|c|c|c|c|c|c|c|c|}
\hline \multirow[b]{2}{*}{ DAY } & \multicolumn{12}{|c|}{ Water Year 1987} \\
\hline & OCT & Nov & DEC & JAN & FEB & MAR & APR & MAY & JUNE & JULY & AUG & SEPT \\
\hline $\begin{array}{l}1 \\
2 \\
3 \\
4 \\
5\end{array}$ & $\begin{array}{r}0.78 \\
.01 \\
1.13 \\
.55 \\
.15\end{array}$ & $\begin{array}{r}0.00 \\
.00 \\
.00 \\
.65 \\
.71\end{array}$ & $\begin{array}{r}0.00 \\
.34 \\
.17 \\
.00 \\
.00\end{array}$ & $\begin{array}{r}0.00 \\
.02 \\
.01 \\
.02 \\
.00\end{array}$ & $\begin{array}{l}0.00 \\
.01 \\
.00 \\
.00 \\
.00\end{array}$ & $\begin{array}{r}0.36 \\
.25 \\
.01 \\
.01 \\
.01\end{array}$ & $\begin{array}{r}0.01 \\
.00 \\
.02 \\
.06 \\
.07\end{array}$ & $\begin{array}{r}0.00 \\
.00 \\
.00 \\
.00 \\
.00\end{array}$ & $\begin{array}{r}0.24 \\
.01 \\
.07 \\
.00 \\
.00\end{array}$ & $\begin{array}{r}0.03 \\
.00 \\
.00 \\
.00 \\
.00\end{array}$ & $\begin{array}{l}0.00 \\
.01 \\
.00 \\
.00 \\
.04\end{array}$ & $\begin{array}{r}0.00 \\
.00 \\
.00 \\
.00 \\
.03\end{array}$ \\
\hline $\begin{array}{r}6 \\
7 \\
8 \\
9 \\
10\end{array}$ & $\begin{array}{l}.04 \\
.00 \\
.00 \\
.00 \\
.00\end{array}$ & $\begin{array}{l}.05 \\
.00 \\
.11 \\
.13 \\
.54\end{array}$ & $\begin{array}{l}.00 \\
.00 \\
.00 \\
.59 \\
.00\end{array}$ & $\begin{array}{l}.00 \\
.00 \\
.00 \\
.00 \\
.00\end{array}$ & $\begin{array}{l}.00 \\
.00 \\
.00 \\
.00 \\
.00\end{array}$ & $\begin{array}{l}.00 \\
.00 \\
.00 \\
.00 \\
.00\end{array}$ & $\begin{array}{l}.06 \\
.00 \\
.00 \\
.00 \\
.00\end{array}$ & $\begin{array}{l}.00 \\
.00 \\
.00 \\
.00 \\
.00\end{array}$ & $\begin{array}{l}.00 \\
.00 \\
.26 \\
.76 \\
.00\end{array}$ & $\begin{array}{l}.01 \\
.01 \\
.00 \\
.00 \\
.00\end{array}$ & $\begin{array}{l}.01 \\
.00 \\
.00 \\
.02 \\
.00\end{array}$ & $\begin{array}{l}.16 \\
.05 \\
.75 \\
.01 \\
.00\end{array}$ \\
\hline $\begin{array}{l}11 \\
12 \\
13 \\
14 \\
15\end{array}$ & $\begin{array}{l}.00 \\
.00 \\
.39 \\
.45 \\
.00\end{array}$ & $\begin{array}{l}.15 \\
.09 \\
.11 \\
.00 \\
.00\end{array}$ & $\begin{array}{l}.00 \\
.00 \\
.00 \\
.00 \\
.00\end{array}$ & $\begin{array}{l}.00 \\
.00 \\
.00 \\
.00 \\
.00\end{array}$ & $\begin{array}{l}.00 \\
.03 \\
.01 \\
.00 \\
.00\end{array}$ & $\begin{array}{l}.00 \\
.00 \\
.00 \\
.00 \\
.45\end{array}$ & $\begin{array}{l}.00 \\
.00 \\
.00 \\
.00 \\
.00\end{array}$ & $\begin{array}{l}.00 \\
.00 \\
.00 \\
.00 \\
.00\end{array}$ & $\begin{array}{l}.00 \\
.23 \\
.82 \\
.72 \\
.16\end{array}$ & $\begin{array}{l}.01 \\
.00 \\
.00 \\
.02 \\
.00\end{array}$ & $\begin{array}{l}.00 \\
.00 \\
.00 \\
.00 \\
.00\end{array}$ & $\begin{array}{l}.06 \\
.00 \\
.01 \\
.00 \\
.00\end{array}$ \\
\hline $\begin{array}{l}16 \\
17 \\
18 \\
19 \\
20\end{array}$ & $\begin{array}{l}.00 \\
.07 \\
.00 \\
.00 \\
.00\end{array}$ & $\begin{array}{l}.00 \\
.00 \\
.07 \\
.30 \\
.09\end{array}$ & $\begin{array}{l}.00 \\
.00 \\
.06 \\
.09 \\
.00\end{array}$ & $\begin{array}{l}.01 \\
.00 \\
.00 \\
.04 \\
.50\end{array}$ & $\begin{array}{l}.00 \\
.00 \\
.00 \\
.00 \\
.00\end{array}$ & $\begin{array}{l}.00 \\
.00 \\
.00 \\
.00 \\
.00\end{array}$ & $\begin{array}{l}.00 \\
.00 \\
.00 \\
.00 \\
.00\end{array}$ & $\begin{array}{l}.00 \\
.00 \\
.00 \\
.50 \\
.75\end{array}$ & $\begin{array}{l}.00 \\
.00 \\
.00 \\
.00 \\
.35\end{array}$ & $\begin{array}{l}.00 \\
.00 \\
.00 \\
.00 \\
.00\end{array}$ & $\begin{array}{l}.00 \\
.02 \\
.00 \\
.00 \\
.00\end{array}$ & $\begin{array}{r}.00 \\
.00 \\
1.06 \\
.13 \\
.01\end{array}$ \\
\hline $\begin{array}{l}21 \\
22 \\
23 \\
24 \\
25\end{array}$ & $\begin{array}{l}.00 \\
.00 \\
.00 \\
.00 \\
.19\end{array}$ & $\begin{array}{l}.08 \\
.07 \\
.00 \\
.01 \\
.23\end{array}$ & $\begin{array}{l}.00 \\
.00 \\
.00 \\
.00 \\
.00\end{array}$ & $\begin{array}{l}.15 \\
.02 \\
.01 \\
.02 \\
.00\end{array}$ & $\begin{array}{l}.00 \\
.00 \\
.43 \\
.00 \\
.00\end{array}$ & $\begin{array}{l}.00 \\
.00 \\
.00 \\
.00 \\
.00\end{array}$ & $\begin{array}{l}.00 \\
.00 \\
.00 \\
.00 \\
.00\end{array}$ & $\begin{array}{l}.00 \\
.00 \\
.00 \\
.00 \\
.00\end{array}$ & $\begin{array}{l}.21 \\
.14 \\
.11 \\
.08 \\
.02\end{array}$ & $\begin{array}{l}.00 \\
.00 \\
.00 \\
.00 \\
.01\end{array}$ & $\begin{array}{l}.00 \\
.00 \\
.00 \\
.00 \\
.00\end{array}$ & $\begin{array}{l}.00 \\
.00 \\
.58 \\
.00 \\
.00\end{array}$ \\
\hline $\begin{array}{l}26 \\
27 \\
28 \\
29 \\
30 \\
31\end{array}$ & $\begin{array}{l}.84 \\
.13 \\
.14 \\
.00 \\
.00 \\
.00\end{array}$ & $\begin{array}{l}.63 \\
.19 \\
.00 \\
.00 \\
.00 \\
--\end{array}$ & $\begin{array}{l}.00 \\
.00 \\
.00 \\
.01 \\
.00 \\
.00\end{array}$ & $\begin{array}{l}.00 \\
.00 \\
.00 \\
.00 \\
.00 \\
.00\end{array}$ & $\begin{array}{l}.00 \\
.00 \\
.00 \\
-- \\
-- \\
--\end{array}$ & $\begin{array}{l}.06 \\
.00 \\
.00 \\
.00 \\
.00 \\
.84\end{array}$ & $\begin{array}{l}.00 \\
.00 \\
.52 \\
.00 \\
.00 \\
--\end{array}$ & $\begin{array}{l}.00 \\
.00 \\
.00 \\
.00 \\
.00 \\
.17\end{array}$ & $\begin{array}{l}.19 \\
.05 \\
.00 \\
.02 \\
.04 \\
--\end{array}$ & $\begin{array}{l}.00 \\
.00 \\
.00 \\
.00 \\
.02 \\
.01\end{array}$ & $\begin{array}{l}.00 \\
.00 \\
.00 \\
.00 \\
.00 \\
.03\end{array}$ & $\begin{array}{l}.00 \\
.00 \\
.00 \\
.00 \\
.25 \\
--\end{array}$ \\
\hline Total & 4.87 & 4.21 & 1.26 & 0.80 & 0.48 & 1.99 & 0.74 & 1.42 & 4.48 & 0.12 & 0.13 & 3.10 \\
\hline \multicolumn{13}{|c|}{$\begin{array}{l}\text { Calendar Year } 1986 \text { Total } 42.02 \\
\text { Water Year } 1987 \text { Total 23.60 }\end{array}$} \\
\hline
\end{tabular}


Table 19.--Total daily precipitation for North Fork Bens Creek from October 1983 through September 1988--Continued [in inches; --, no data]

\begin{tabular}{|c|c|c|c|c|c|c|c|c|c|c|c|c|}
\hline \multirow[b]{2}{*}{ DAY } & \multicolumn{12}{|c|}{ Water Year 1988} \\
\hline & $\propto C T$ & Nov & DEC & JAN & FEB & MAR & APR & MAY & JUNE & JULY & AUG & SEPT \\
\hline $\begin{array}{l}1 \\
2 \\
3 \\
4 \\
5\end{array}$ & $\begin{array}{r}0.07 \\
.69 \\
.02 \\
.00 \\
.00\end{array}$ & $\begin{array}{r}0.00 \\
.00 \\
.00 \\
.00 \\
.00\end{array}$ & $\begin{array}{r}0.00 \\
.11 \\
.25 \\
.03 \\
.03\end{array}$ & $\begin{array}{r}0.25 \\
.00 \\
.00 \\
.00 \\
.00\end{array}$ & $\begin{array}{r}0.00 \\
1.46 \\
.00 \\
.52 \\
.00\end{array}$ & $\begin{array}{r}0.00 \\
.00 \\
.00 \\
1.73 \\
.00\end{array}$ & $\begin{array}{r}0.06 \\
.01 \\
.03 \\
.34 \\
.00\end{array}$ & $\begin{array}{r}0.00 \\
.00 \\
.00 \\
.00 \\
.33\end{array}$ & $\begin{array}{r}0.00 \\
.44 \\
.00 \\
.00 \\
.00\end{array}$ & $\begin{array}{r}0.00 \\
.00 \\
.00 \\
.00 \\
.00\end{array}$ & $\begin{array}{r}0.00 \\
.00 \\
.00 \\
.00 \\
.00\end{array}$ & $\begin{array}{r}0.00 \\
.00 \\
.00 \\
1.48 \\
.21\end{array}$ \\
\hline $\begin{array}{r}6 \\
7 \\
8 \\
9 \\
10\end{array}$ & $\begin{array}{l}.13 \\
.22 \\
.13 \\
.00 \\
.09\end{array}$ & $\begin{array}{l}.00 \\
.00 \\
.00 \\
.36 \\
.66\end{array}$ & $\begin{array}{l}.00 \\
.00 \\
.00 \\
.00 \\
.06\end{array}$ & $\begin{array}{l}.00 \\
.00 \\
.00 \\
.00 \\
.00\end{array}$ & $\begin{array}{l}.00 \\
.00 \\
.00 \\
.00 \\
.00\end{array}$ & $\begin{array}{l}.00 \\
.00 \\
.00 \\
.00 \\
.00\end{array}$ & $\begin{array}{l}.69 \\
.34 \\
.01 \\
.00 \\
.00\end{array}$ & $\begin{array}{l}.26 \\
.09 \\
.00 \\
.00 \\
.56\end{array}$ & $\begin{array}{r}.00 \\
.00 \\
.00 \\
1.16 \\
.00\end{array}$ & $\begin{array}{l}.00 \\
.00 \\
.00 \\
.00 \\
.00\end{array}$ & $\begin{array}{l}.60 \\
.00 \\
.00 \\
.00 \\
.00\end{array}$ & $\begin{array}{l}.00 \\
.00 \\
.00 \\
.00 \\
.00\end{array}$ \\
\hline $\begin{array}{l}11 \\
12 \\
13 \\
14 \\
15\end{array}$ & $\begin{array}{l}.13 \\
.00 \\
.00 \\
.00 \\
.00\end{array}$ & $\begin{array}{l}.01 \\
.00 \\
.00 \\
.00 \\
.00\end{array}$ & $\begin{array}{l}.00 \\
.04 \\
.02 \\
.01 \\
.43\end{array}$ & $\begin{array}{l}.00 \\
.00 \\
.01 \\
.00 \\
.00\end{array}$ & $\begin{array}{l}.00 \\
.08 \\
.00 \\
.00 \\
.00\end{array}$ & $\begin{array}{l}.00 \\
.00 \\
.00 \\
.00 \\
.00\end{array}$ & $\begin{array}{l}.00 \\
.00 \\
.00 \\
.00 \\
.17\end{array}$ & $\begin{array}{l}.12 \\
.01 \\
.00 \\
.05 \\
.00\end{array}$ & $\begin{array}{l}.00 \\
.00 \\
.00 \\
.00 \\
.00\end{array}$ & $\begin{array}{l}.00 \\
.07 \\
.00 \\
.00 \\
.00\end{array}$ & $\begin{array}{l}.00 \\
.00 \\
.00 \\
.00 \\
.00\end{array}$ & $\begin{array}{r}.00 \\
.00 \\
1.47 \\
.42 \\
.00\end{array}$ \\
\hline $\begin{array}{l}16 \\
17 \\
18 \\
19 \\
20\end{array}$ & $\begin{array}{l}.00 \\
.00 \\
.00 \\
.00 \\
.21\end{array}$ & $\begin{array}{l}.00 \\
.18 \\
.01 \\
.00 \\
.30\end{array}$ & $\begin{array}{l}.04 \\
.00 \\
.00 \\
.00 \\
.38\end{array}$ & $\begin{array}{l}.00 \\
.00 \\
.15 \\
.64 \\
.55\end{array}$ & $\begin{array}{l}.00 \\
.00 \\
.00 \\
.02 \\
.46\end{array}$ & $\begin{array}{l}.00 \\
.00 \\
.00 \\
.00 \\
.03\end{array}$ & $\begin{array}{l}.01 \\
.00 \\
.20 \\
.00 \\
.00\end{array}$ & $\begin{array}{l}.05 \\
.00 \\
.00 \\
.90 \\
.89\end{array}$ & $\begin{array}{l}.22 \\
.08 \\
.00 \\
.00 \\
.00\end{array}$ & $\begin{array}{l}.00 \\
.00 \\
.04 \\
.20 \\
.43\end{array}$ & $\begin{array}{l}.27 \\
.01 \\
.52 \\
.43 \\
.00\end{array}$ & $\begin{array}{r}.00 \\
.00 \\
1.68 \\
.00 \\
.00\end{array}$ \\
\hline $\begin{array}{l}21 \\
22 \\
23 \\
24 \\
25\end{array}$ & $\begin{array}{l}.05 \\
.00 \\
.00 \\
.03 \\
.01\end{array}$ & $\begin{array}{l}.09 \\
.00 \\
.01 \\
.00 \\
.06\end{array}$ & $\begin{array}{l}.01 \\
.00 \\
.00 \\
.00 \\
.00\end{array}$ & $\begin{array}{l}.00 \\
.00 \\
.00 \\
.00 \\
.01\end{array}$ & $\begin{array}{l}.02 \\
.00 \\
.00 \\
.00 \\
.00\end{array}$ & $\begin{array}{l}.00 \\
.00 \\
.00 \\
.00 \\
.57\end{array}$ & $\begin{array}{l}.01 \\
.00 \\
.40 \\
.01 \\
.00\end{array}$ & $\begin{array}{l}.07 \\
.00 \\
.00 \\
.35 \\
.07\end{array}$ & $\begin{array}{l}.00 \\
.00 \\
.15 \\
.00 \\
.00\end{array}$ & $\begin{array}{r}2.11 \\
.15 \\
.00 \\
1.25 \\
.00\end{array}$ & $\begin{array}{r}.02 \\
.00 \\
.04 \\
1.03 \\
.00\end{array}$ & $\begin{array}{l}.28 \\
.00 \\
.19 \\
.01 \\
.44\end{array}$ \\
\hline $\begin{array}{l}26 \\
27 \\
28 \\
29 \\
30 \\
31\end{array}$ & $\begin{array}{l}.00 \\
.28 \\
.04 \\
.00 \\
.00 \\
.00\end{array}$ & $\begin{array}{r}.01 \\
.03 \\
.00 \\
1.06 \\
.02 \\
-.02\end{array}$ & $\begin{array}{l}.67 \\
.00 \\
.30 \\
.09 \\
.00 \\
.03\end{array}$ & $\begin{array}{l}.08 \\
.00 \\
.00 \\
.00 \\
.00 \\
.00\end{array}$ & $\begin{array}{l}.00 \\
.00 \\
.00 \\
.00 \\
---\end{array}$ & $\begin{array}{l}.18 \\
.02 \\
.00 \\
.00 \\
.00 \\
.01\end{array}$ & $\begin{array}{l}.00 \\
.01 \\
.12 \\
.19 \\
.00 \\
--\end{array}$ & $\begin{array}{l}.00 \\
.00 \\
.00 \\
.00 \\
.00 \\
.00\end{array}$ & $\begin{array}{l}.00 \\
.00 \\
.00 \\
.00 \\
.00 \\
-\end{array}$ & $\begin{array}{l}.00 \\
.00 \\
.21 \\
.00 \\
.00 \\
.00\end{array}$ & $\begin{array}{r}.00 \\
.00 \\
.00 \\
1.14 \\
.55 \\
.00\end{array}$ & $\begin{array}{l}.42 \\
.00 \\
.00 \\
.00 \\
.00 \\
--\end{array}$ \\
\hline Total & 2.10 & 2.80 & 2.50 & 1.69 & 2.56 & 2.54 & 2.60 & 3.75 & 2.05 & 4.46 & 4.61 & 6.60 \\
\hline Water & & Tot & & & & & & & & & & \\
\hline
\end{tabular}

In order to determine the relation of precipitation during the study to that of the norm, monthly averages were computed from 23 years of record for the Boswell climatological station (National Oceanic and Atmospheric Administration, 1960-83). Figure 16 shows the comparison of monthly precipitation observed at North Fork Bens Creek with computed averages. Mean annual precipitation for the 23 years was 40.03 inches. Monthly precipitation during the 1984 water year was substantially greater than the average for 9 of 12 months, and annual precipitation was 46 percent above the average. Precipitation during the 1985 water year was greater than the norm for 5 of 12 months, and the annual total was 3.7 percent above the average. During the 1986 water year, 5 of 12 months had total precipitation greater than the average. The annual total for 1986 however, was only 1.2 percent above normal. Precipitation for water years 1987 and 1988 were below normal by 41 and 4.4 percent, respectively. 

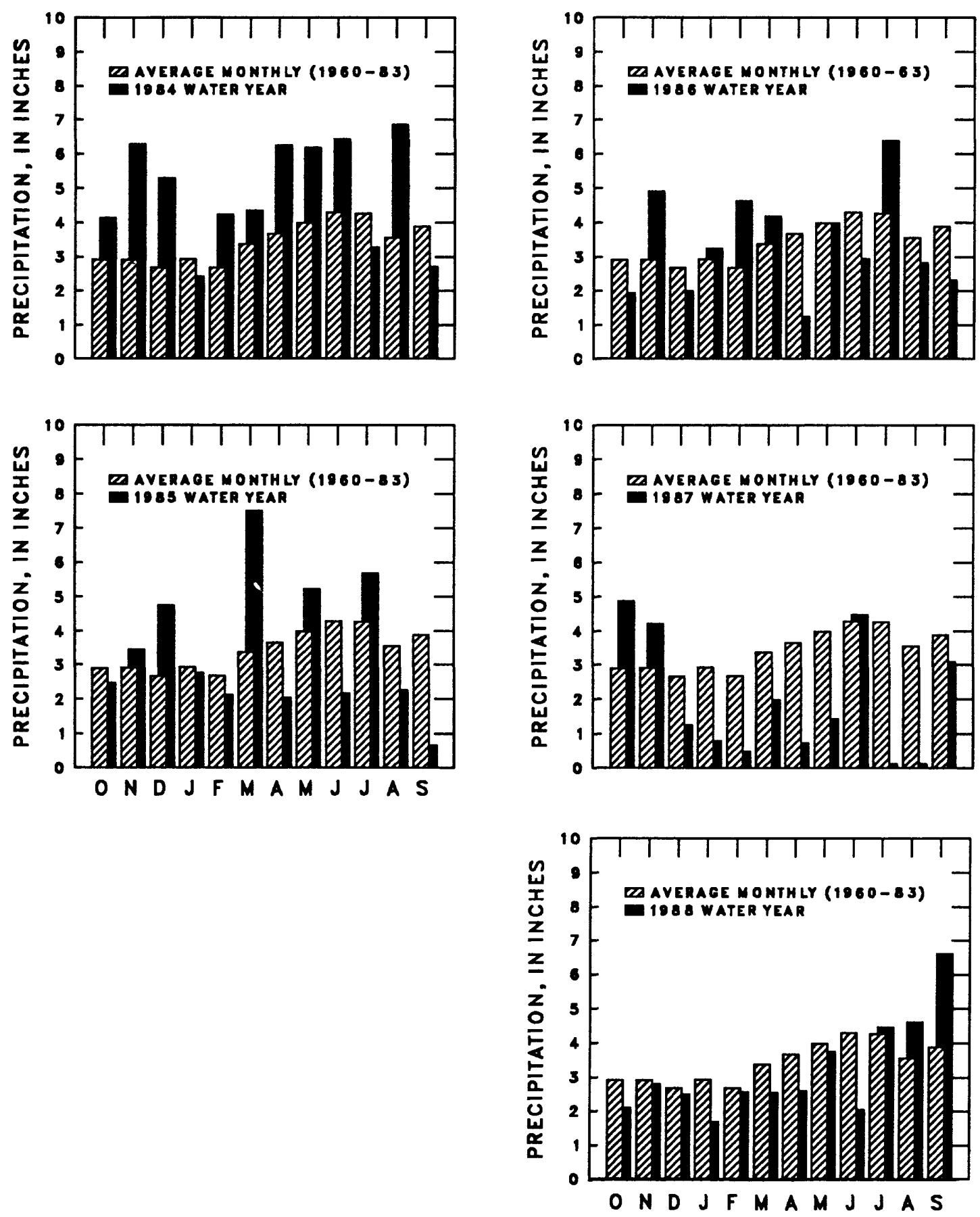

Figure 16.--Comparison of average monthly precipitation for 1984 through 1988. 


\section{Streamflow}

A concrete weir presently at the gaging station was in place for about 30 years prior to the beginning of the study. This control was probably used to estimate flows by water-supply managers of the North Fork Reservoir. It is not known, however, if streamflow record was collected at this site in the past, because no published record exists for North Fork Bens Creek prior to the 1985 water year. Continuous streamflow was recorded for the 1985 and 1988 water years. Daily streamflow and summary statistics for these water years are 1 isted in tables 20 and 21 .

Table 20.--Daily mean discharge data for North Fork Bens Creek from October 1984 through September 1985 [data are in cubic feet per second unless stated otherwise; in., inches; --, no data]

\begin{tabular}{|c|c|c|c|c|c|c|c|c|c|c|c|c|}
\hline DAY & OCT & NOV & DEC & JAN & FEB & MAR & APR & MAY & JUNE & JULY & AUG & SEPT \\
\hline $\begin{array}{l}1 \\
2 \\
3 \\
4 \\
5\end{array}$ & $\begin{array}{l}1.9 \\
1.0 \\
1.1 \\
1.1 \\
1.0\end{array}$ & $\begin{array}{r}2.4 \\
3.9 \\
3.8 \\
5.5 \\
11\end{array}$ & $\begin{array}{l}12 \\
12 \\
12 \\
11 \\
10\end{array}$ & $\begin{array}{c}14 \\
12 \\
10 \\
9.2 \\
8.4\end{array}$ & $\begin{array}{l}2.7 \\
2.8 \\
2.5 \\
2.5 \\
2.7\end{array}$ & $\begin{array}{c}14 \\
12 \\
11 \\
9.6 \\
11\end{array}$ & $\begin{array}{l}66 \\
35 \\
20 \\
15 \\
12\end{array}$ & $\begin{array}{l}2.8 \\
13 \\
34 \\
16 \\
12\end{array}$ & $\begin{array}{l}3.0 \\
2.8 \\
2.6 \\
2.5 \\
2.7\end{array}$ & $\begin{array}{l}0.92 \\
.92 \\
2.3 \\
1.8 \\
1.2\end{array}$ & $\begin{array}{l}2.9 \\
2.6 \\
2.4 \\
2.2 \\
2.1\end{array}$ & $\begin{array}{r}0.98 \\
.91 \\
.84 \\
.83 \\
.74\end{array}$ \\
\hline $\begin{array}{r}6 \\
7 \\
8 \\
9 \\
10\end{array}$ & $\begin{array}{l}1.0 \\
1.0 \\
1.0 \\
1.0 \\
1.0\end{array}$ & $\begin{array}{r}11 \\
9.4 \\
8.3 \\
7.8 \\
7.8\end{array}$ & $\begin{array}{l}9.7 \\
8.5 \\
7.7 \\
7.0 \\
6.6\end{array}$ & $\begin{array}{l}7.4 \\
6.9 \\
6.2 \\
5.8 \\
5.3\end{array}$ & $\begin{array}{l}2.8 \\
2.4 \\
2.6 \\
2.4 \\
2.4\end{array}$ & $\begin{array}{l}9.4 \\
8.9 \\
9.4 \\
8.9 \\
8.5\end{array}$ & $\begin{array}{r}11 \\
9.5 \\
8.9 \\
8.2 \\
7.5\end{array}$ & $\begin{array}{l}9.7 \\
8.1 \\
6.8 \\
6.0 \\
5.5\end{array}$ & $\begin{array}{l}2.4 \\
2.3 \\
2.2 \\
2.0 \\
1.9\end{array}$ & $\begin{array}{l}1.1 \\
1.0 \\
1.4 \\
7.0 \\
4.1\end{array}$ & $\begin{array}{l}2.0 \\
1.9 \\
1.9 \\
1.8 \\
1.6\end{array}$ & $\begin{array}{r}.74 \\
.89 \\
1.0 \\
.88 \\
.74\end{array}$ \\
\hline $\begin{array}{l}11 \\
12 \\
13 \\
14 \\
15\end{array}$ & $\begin{array}{l}1.0 \\
1.0 \\
1.0 \\
1.0 \\
1.0\end{array}$ & $\begin{array}{l}7.5 \\
7.3 \\
7.0 \\
6.7 \\
6.7\end{array}$ & $\begin{array}{l}6.9 \\
7.3 \\
10 \\
11 \\
12\end{array}$ & $\begin{array}{l}5.2 \\
4.9 \\
4.9 \\
4.8 \\
4.5\end{array}$ & $\begin{array}{l}2.4 \\
5.2 \\
5.8 \\
4.9 \\
4.6\end{array}$ & $\begin{array}{l}8.5 \\
15 \\
13 \\
13 \\
12\end{array}$ & $\begin{array}{l}9.1 \\
9.2 \\
9.5 \\
9.5 \\
8.9\end{array}$ & $\begin{array}{l}5.1 \\
4.7 \\
4.4 \\
4.3 \\
3.9\end{array}$ & $\begin{array}{l}1.7 \\
1.9 \\
2.0 \\
1.8 \\
1.6\end{array}$ & $\begin{array}{l}3.3 \\
2.9 \\
2.9 \\
4.2 \\
5.1\end{array}$ & $\begin{array}{l}1.5 \\
1.4 \\
1.3 \\
1.3 \\
1.3\end{array}$ & $\begin{array}{l}.74 \\
.73 \\
.65 \\
.65 \\
.65\end{array}$ \\
\hline $\begin{array}{l}16 \\
17 \\
18 \\
19 \\
20\end{array}$ & $\begin{array}{l}.74 \\
1.2 \\
1.8 \\
1.1 \\
1.1\end{array}$ & $\begin{array}{l}7.7 \\
7.5 \\
7.5 \\
7.2 \\
6.5\end{array}$ & $\begin{array}{l}12 \\
11 \\
12 \\
10 \\
11\end{array}$ & $\begin{array}{l}3.6 \\
3.8 \\
4.0 \\
3.7 \\
2.9\end{array}$ & $\begin{array}{l}4.3 \\
4.3 \\
4.0 \\
3.9 \\
3.5\end{array}$ & $\begin{array}{r}11 \\
9.7 \\
8.8 \\
7.8 \\
8.0\end{array}$ & $\begin{array}{l}8.2 \\
7.2 \\
6.3 \\
5.9 \\
5.6\end{array}$ & $\begin{array}{l}3.7 \\
4.3 \\
4.9 \\
4.2 \\
4.0\end{array}$ & $\begin{array}{l}1.7 \\
1.7 \\
1.6 \\
1.5 \\
1.4\end{array}$ & $\begin{array}{l}4.4 \\
4.0 \\
3.7 \\
3.4 \\
3.2\end{array}$ & $\begin{array}{l}1.7 \\
1.4 \\
1.1 \\
1.1 \\
1.1\end{array}$ & $\begin{array}{l}.65 \\
.63 \\
.57 \\
.57 \\
.57\end{array}$ \\
\hline $\begin{array}{l}21 \\
22 \\
23 \\
24 \\
25\end{array}$ & $\begin{array}{l}1.0 \\
1.7 \\
1.9 \\
1.9 \\
1.7\end{array}$ & $\begin{array}{l}5.9 \\
5.4 \\
5.2 \\
5.0 \\
4.8\end{array}$ & $\begin{array}{l}16 \\
20 \\
16 \\
13 \\
12\end{array}$ & $\begin{array}{l}2.9 \\
2.9 \\
3.1 \\
3.1 \\
3.1\end{array}$ & $\begin{array}{r}3.7 \\
5.9 \\
17 \\
46 \\
64\end{array}$ & $\begin{array}{l}7.3 \\
6.9 \\
12 \\
15 \\
16\end{array}$ & $\begin{array}{l}5.2 \\
4.9 \\
4.6 \\
4.3 \\
4.2\end{array}$ & $\begin{array}{l}4.0 \\
3.7 \\
3.7 \\
3.4 \\
3.3\end{array}$ & $\begin{array}{r}1.4 \\
1.3 \\
1.6 \\
1.1 \\
.98\end{array}$ & $\begin{array}{l}3.3 \\
6.2 \\
4.6 \\
4.2 \\
4.0\end{array}$ & $\begin{array}{c}1.1 \\
1.0 \\
.99 \\
1.2 \\
1.8\end{array}$ & $\begin{array}{l}.57 \\
.57 \\
.57 \\
.65 \\
.72\end{array}$ \\
\hline $\begin{array}{l}26 \\
27 \\
28 \\
29 \\
30 \\
31\end{array}$ & $\begin{array}{l}1.9 \\
1.9 \\
1.9 \\
2.5 \\
2.6 \\
2.4\end{array}$ & $\begin{array}{r}4.6 \\
4.3 \\
7.4 \\
21 \\
21 \\
\end{array}$ & $\begin{array}{c}10 \\
9.8 \\
9.5 \\
9.0 \\
18 \\
17\end{array}$ & $\begin{array}{l}3.0 \\
2.8 \\
2.8 \\
2.8 \\
2.7 \\
2.7\end{array}$ & $\begin{array}{r}36 \\
23 \\
17 \\
-- \\
-- \\
--\end{array}$ & $\begin{array}{l}13 \\
11 \\
10 \\
17 \\
30 \\
65\end{array}$ & $\begin{array}{r}3.8 \\
3.6 \\
3.4 \\
3.1 \\
3.0 \\
--\end{array}$ & $\begin{array}{l}3.1 \\
2.9 \\
4.0 \\
3.1 \\
2.6 \\
3.7\end{array}$ & $\begin{array}{l}.92 \\
.92 \\
.92 \\
.92 \\
.89 \\
.--\end{array}$ & $\begin{array}{l}4.3 \\
4.2 \\
3.6 \\
3.4 \\
3.1 \\
3.0\end{array}$ & $\begin{array}{c}1.3 \\
.99 \\
.92 \\
.92 \\
1.0 \\
1.2\end{array}$ & $\begin{array}{l}.65 \\
.65 \\
.65 \\
.65 \\
.57 \\
.-\end{array}$ \\
\hline Total & 43.34 & 207.1 & 348.0 & 159.4 & 281.3 & 412.7 & 312.6 & 194.9 & 52.25 & 102.74 & 47.02 & 21.21 \\
\hline Mean & 1.40 & 6.90 & 11.2 & 5.14 & 10.0 & 13.3 & 10.4 & 6.29 & 1.74 & 3.31 & 1.52 & .71 \\
\hline Max & 2.6 & 11 & 20 & 14 & 64 & 65 & 66 & 34 & 3.0 & 7.0 & 2.9 & 1.0 \\
\hline Min & .74 & 2.4 & 6.6 & 2.7 & 2.4 & 6.9 & 3.0 & 2.6 & .89 & .92 & .92 & .57 \\
\hline $\mathrm{CFSM}^{1}$ & .41 & 2.00 & 3.25 & 1.49 & 2.90 & 3.86 & 3.01 & 1.82 & .50 & .96 & .44 & .21 \\
\hline in. & .47 & 2.23 & 3.75 & 1.72 & 3.03 & 4.45 & 3.37 & 2.10 & .56 & 1.11 & .51 & .23 \\
\hline
\end{tabular}

Water Year 1985 Total 2182.56 Mean 5.98 Max 66 Min .57 CFSM $^{1} 1.73 \quad$ In. 23.53

${ }^{1}$ Cubic feet per second per mile. 
Table 21.--Daily mean discharge for North Fork Bens Creek from October 1987 through September 1988 [data are in cubic feet per second unless stated otherwise; in., inches; --, no data]

\begin{tabular}{|c|c|c|c|c|c|c|c|c|c|c|c|c|}
\hline DAY & OCT & NOV & DEC & JAN & FEB & MAR & APR & MAY & JUNE & JULY & AUG & SEPT \\
\hline $\begin{array}{l}1 \\
2 \\
3 \\
4 \\
5\end{array}$ & $\begin{array}{r}5.7 \\
7.1 \\
12 \\
11 \\
9.7\end{array}$ & $\begin{array}{l}2.5 \\
2.5 \\
2.5 \\
2.5 \\
2.5\end{array}$ & $\begin{array}{c}24 \\
17 \\
13 \\
11 \\
8.6\end{array}$ & $\begin{array}{c}13 \\
11 \\
9.6 \\
8.4 \\
7.9\end{array}$ & $\begin{array}{l}9.2 \\
36 \\
36 \\
36 \\
27\end{array}$ & $\begin{array}{l}4.4 \\
4.1 \\
7.3 \\
39 \\
31\end{array}$ & $\begin{array}{l}8.8 \\
8.0 \\
7.2 \\
7.3 \\
6.4\end{array}$ & $\begin{array}{c}14 \\
11 \\
9.7 \\
8.6 \\
12\end{array}$ & $\begin{array}{l}5.1 \\
4.8 \\
4.3 \\
3.9 \\
3.5\end{array}$ & $\begin{array}{l}1.2 \\
1.3 \\
1.2 \\
1.2 \\
1.2\end{array}$ & $\begin{array}{l}1.7 \\
1.5 \\
1.4 \\
1.3 \\
1.4\end{array}$ & $\begin{array}{l}5.5 \\
4.6 \\
4.0 \\
17 \\
15\end{array}$ \\
\hline $\begin{array}{r}6 \\
7 \\
8 \\
9 \\
10\end{array}$ & $\begin{array}{l}8.7 \\
8.1 \\
7.5 \\
6.4 \\
5.9\end{array}$ & $\begin{array}{l}2.4 \\
2.4 \\
2.3 \\
2.3 \\
2.5\end{array}$ & $\begin{array}{r}7.5 \\
6.4 \\
5.9 \\
7.5 \\
12\end{array}$ & $\begin{array}{l}8.4 \\
8.1 \\
8.5 \\
6.3 \\
4.1\end{array}$ & $\begin{array}{c}20 \\
16 \\
12 \\
11 \\
9.2\end{array}$ & $\begin{array}{l}21 \\
17 \\
15 \\
20 \\
32\end{array}$ & $\begin{array}{c}6.4 \\
10 \\
10 \\
10 \\
9.3\end{array}$ & $\begin{array}{l}15 \\
16 \\
15 \\
13 \\
15\end{array}$ & $\begin{array}{l}3.3 \\
3.1 \\
3.0 \\
5.4 \\
3.1\end{array}$ & $\begin{array}{l}1.2 \\
1.1 \\
1.1 \\
1.1 \\
1.1\end{array}$ & $\begin{array}{l}6.1 \\
2.4 \\
2.0 \\
1.7 \\
1.6\end{array}$ & $\begin{array}{r}11 \\
8.7 \\
7.1 \\
5.9 \\
5.1\end{array}$ \\
\hline $\begin{array}{l}11 \\
12 \\
13 \\
14 \\
15\end{array}$ & $\begin{array}{l}5.9 \\
5.4 \\
5.2 \\
4.8 \\
4.6\end{array}$ & $\begin{array}{l}2.5 \\
2.5 \\
2.7 \\
4.2 \\
5.4\end{array}$ & $\begin{array}{r}12 \\
11 \\
9.5 \\
7.9 \\
9.5\end{array}$ & $\begin{array}{l}3.7 \\
3.4 \\
3.3 \\
3.0 \\
2.9\end{array}$ & $\begin{array}{l}7.8 \\
7.3 \\
6.3 \\
6.5 \\
5.2\end{array}$ & $\begin{array}{l}25 \\
20 \\
19 \\
16 \\
14\end{array}$ & $\begin{array}{l}8.5 \\
7.8 \\
7.1 \\
6.2 \\
5.8\end{array}$ & $\begin{array}{l}13 \\
11 \\
10 \\
9.5 \\
8.4\end{array}$ & $\begin{array}{l}2.8 \\
2.6 \\
2.4 \\
2.2 \\
2.1\end{array}$ & $\begin{array}{l}1.1 \\
1.1 \\
1.1 \\
1.1 \\
1.0\end{array}$ & $\begin{array}{l}1.5 \\
1.4 \\
1.4 \\
1.3 \\
1.3\end{array}$ & $\begin{array}{l}4.4 \\
3.9 \\
6.5 \\
4.3 \\
3.7\end{array}$ \\
\hline $\begin{array}{l}16 \\
17 \\
18 \\
19 \\
20\end{array}$ & $\begin{array}{l}4.3 \\
4.1 \\
4.0 \\
3.8 \\
3.7\end{array}$ & $\begin{array}{l}5.6 \\
5.8 \\
6.4 \\
5.9 \\
5.9\end{array}$ & $\begin{array}{r}9.2 \\
8.4 \\
7.7 \\
6.8 \\
13\end{array}$ & $\begin{array}{r}3.0 \\
2.5 \\
3.5 \\
4.0 \\
22\end{array}$ & $\begin{array}{l}5.0 \\
4.4 \\
4.4 \\
4.4 \\
5.3\end{array}$ & $\begin{array}{r}12 \\
9.8 \\
8.9 \\
8.1 \\
7.4\end{array}$ & $\begin{array}{l}5.4 \\
5.0 \\
4.8 \\
4.4 \\
4.1\end{array}$ & $\begin{array}{l}7.7 \\
6.8 \\
12 \\
21 \\
27\end{array}$ & $\begin{array}{l}2.0 \\
2.0 \\
2.0 \\
1.9 \\
1.7\end{array}$ & $\begin{array}{l}1.0 \\
1.0 \\
1.0 \\
1.2 \\
7.1\end{array}$ & $\begin{array}{l}1.4 \\
1.2 \\
1.6 \\
1.5 \\
1.4\end{array}$ & $\begin{array}{l}2^{3.4} \\
20 \\
15 \\
12\end{array}$ \\
\hline $\begin{array}{l}21 \\
22 \\
23 \\
24 \\
25\end{array}$ & $\begin{array}{l}3.5 \\
3.4 \\
3.2 \\
3.1 \\
2.7\end{array}$ & $\begin{array}{l}5.9 \\
5.6 \\
5.4 \\
7.2 \\
8.4\end{array}$ & $\begin{array}{l}16 \\
14 \\
12 \\
10 \\
11\end{array}$ & $\begin{array}{c}15 \\
12 \\
10 \\
9.1 \\
8.3\end{array}$ & $\begin{array}{l}5.1 \\
5.5 \\
5.7 \\
5.8 \\
5.7\end{array}$ & $\begin{array}{l}6.3 \\
5.7 \\
6.2 \\
8.0 \\
9.7\end{array}$ & $\begin{array}{l}3.9 \\
3.6 \\
3.6 \\
3.6 \\
3.4\end{array}$ & $\begin{array}{l}33 \\
25 \\
18 \\
18 \\
13\end{array}$ & $\begin{array}{l}1.6 \\
1.6 \\
1.5 \\
1.5 \\
1.4\end{array}$ & $\begin{array}{l}8.9 \\
3.3 \\
3.8 \\
4.4 \\
3.5\end{array}$ & $\begin{array}{r}1.2 \\
1.1 \\
1.8 \\
11 \\
3.8\end{array}$ & $\begin{array}{l}9.4 \\
7.7 \\
7.0 \\
6.0 \\
6.6\end{array}$ \\
\hline $\begin{array}{l}26 \\
27 \\
28 \\
29 \\
30 \\
31\end{array}$ & $\begin{array}{l}2.6 \\
2.8 \\
3.1 \\
2.7 \\
2.5 \\
2.5\end{array}$ & $\begin{array}{r}8.4 \\
8.1 \\
7.7 \\
37 \\
35 \\
-\end{array}$ & $\begin{array}{r}12 \\
12 \\
12 \\
11 \\
9.0 \\
8.1\end{array}$ & $\begin{array}{l}7.3 \\
6.7 \\
5.9 \\
5.7 \\
5.1 \\
5.6\end{array}$ & $\begin{array}{r}5.4 \\
5.2 \\
4.8 \\
4.4 \\
-. \\
--\end{array}$ & $\begin{array}{c}19 \\
17 \\
15 \\
12 \\
11 \\
9.5\end{array}$ & $\begin{array}{r}3.3 \\
3.2 \\
3.4 \\
8.9 \\
19 \\
\end{array}$ & $\begin{array}{r}11 \\
9.6 \\
8.3 \\
7.3 \\
6.3 \\
5.7\end{array}$ & $\begin{array}{l}1.4 \\
1.4 \\
1.3 \\
1.3 \\
1.3 \\
--\end{array}$ & $\begin{array}{l}3.1 \\
2.7 \\
2.4 \\
2.1 \\
1.9 \\
1.8\end{array}$ & $\begin{array}{c}3.0 \\
2.4 \\
2.1 \\
15 \\
13 \\
8.4\end{array}$ & $\begin{array}{r}6.3 \\
5.9 \\
5.6 \\
5.2 \\
4.7 \\
---\end{array}$ \\
\hline Total & 160.0 & 200.0 & 335.0 & 227.3 & 316.6 & 450.4 & 198.4 & 410.9 & 75.5 & 66.3 & 97.9 & 245.5 \\
\hline Mean & 5.16 & 6.67 & 10.8 & 7.33 & 10.9 & 14.5 & 6.61 & 13.3 & 2.52 & 2.14 & 3.16 & 8.18 \\
\hline $\operatorname{Max}$ & 12 & 37 & 24 & 22 & 36 & 39 & 19 & 33 & 5.4 & 8.9 & 15 & 24 \\
\hline Min & 2.5 & 2.3 & 5.9 & 2.5 & 4.4 & 4.1 & 3.2 & 5.7 & 1.3 & 1.0 & 1.1 & 3.4 \\
\hline $\mathrm{CFSM}^{1}$ & 1.50 & 1.93 & 3.13 & 2.13 & 3.16 & 4.21 & 1.92 & 3.84 & .73 & .62 & .92 & 2.37 \\
\hline In & 1.73 & 2.16 & 3.61 & 2.45 & 3.41 & 4.86 & 2.14 & 4.43 & .81 & .71 & 1.06 & 2.65 \\
\hline
\end{tabular}

Water Year 1988 Total 2783.8 Mean 7.61 Max 39 Min 1.0 CFSM $2.20 \quad$ In. 2 30.02

${ }^{1}$ Cubic feet per second per mile.

The stage-discharge relation during the 1985 water year was defined by 12 stream-discharge measurements. The highest discharge measured during 1985 was 36 percent lower than the maximum recorded discharge for that year. The lowest discharge measured was 18 percent higher than the minimum recorded for that year.

The stage-discharge relation was changed in 1988 on the basis of 10 stream discharge measurements. Erosion of the edges of the control resulted in more flow at gage heights equivalent to those of the lower end of the rating in 1985. A new rating curve was developed and adjusted the stagedischarge relation for the 1988 water year. The highest stream discharge measured during the 1988 water year was 62 percent lower than the maximum recorded discharge. The lowest stream discharge measured was 2 percent higher than the lowest recorded discharge for that year. 
A monthly streamflow bar graph and daily mean streamflow hydrographs for North Fork Bens Creek show the characteristics and seasonality of annual streamflow (fig. 17 and 18). An average of $2,500 \mathrm{ft}^{3} / \mathrm{s}$ of water flows from the North Fork Bens Creek watershed annually. About 70 percent of the annual flow occurs from November to April. The remaining 30 percent of annual flows occur during May to October when streamflow decreases as a result of increased evapotranspiration. The maximum monthly streamflow for both water years occurred in March (fig. 18). The minimum monthly streamflow for water years 1985 and 1988 occurred in September and July, respectively. Maximum daily flows for 1985 and 1988 were 66 and $39 \mathrm{ft}^{3} / \mathrm{s}$, respectively. Minimum daily flows for 1985 and 1988 were 0.57 and $1.0 \mathrm{ft}^{3} / \mathrm{s}$, respectively.

Comparison of peak flow with the daily mean discharge for the same day illustrates the "flashiness" of stream discharge during a storm. For example, a maximum peak discharge of $92 \mathrm{ft}^{3} / \mathrm{s}$ occurred on March 31, 1985; the daily mean for that day was $65 \mathrm{ft}^{3} / \mathrm{s}$ or 29 percent lower than peak discharge. A similar example of "flashy" hydrologic behavior is noted during the 1988 water year. A peak discharge of $67 \mathrm{ft}^{3} / \mathrm{s}$ occurred on November 29, 1987; the daily mean for that day was 45 percent less than the peak. Although the duration of peak flows is related to the magnitude and duration of the precipitation event, streamflow generally recovers to base flow within hours after the end of the storm.

A flow-duration curve was computed based on both years of continuous data for North Fork Bens Creek (fig. 19). A flow-duration curve is a cumulativefrequency curve that shows the percentage of time that discharges were equalled or exceeded during a given period of record. The duration curve is a useful tool in certain water-supply and model calibration investigations by showing the magnitude and persistence of base runoffs. A duration curve with a uniformly steep slope indicates that the contribution of ground-water flow is small in comparison to that of the more variable, direct-runoff component (Searcy, 1959). The flow-duration curve for North Fork Bens Creek represents flow conditions influenced by normal precipitation during the 1985 water year and below-normal precipitation for 1988. However, the record was not related with another stream having long-term record, limiting interpretations based on this curve. 

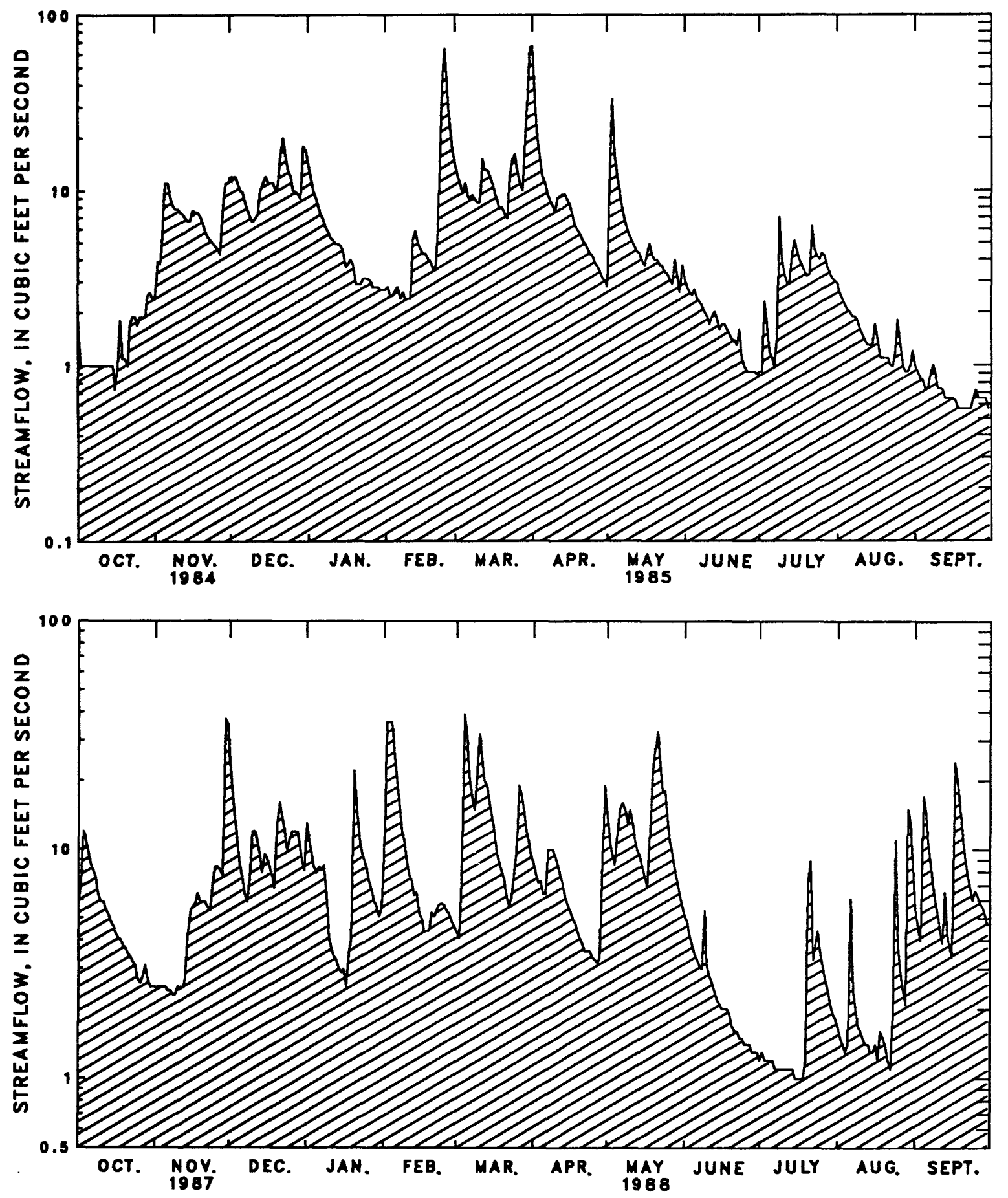

Figure 17.--Hydrographs of daily discharge for North Fork Bens Creek.

54 


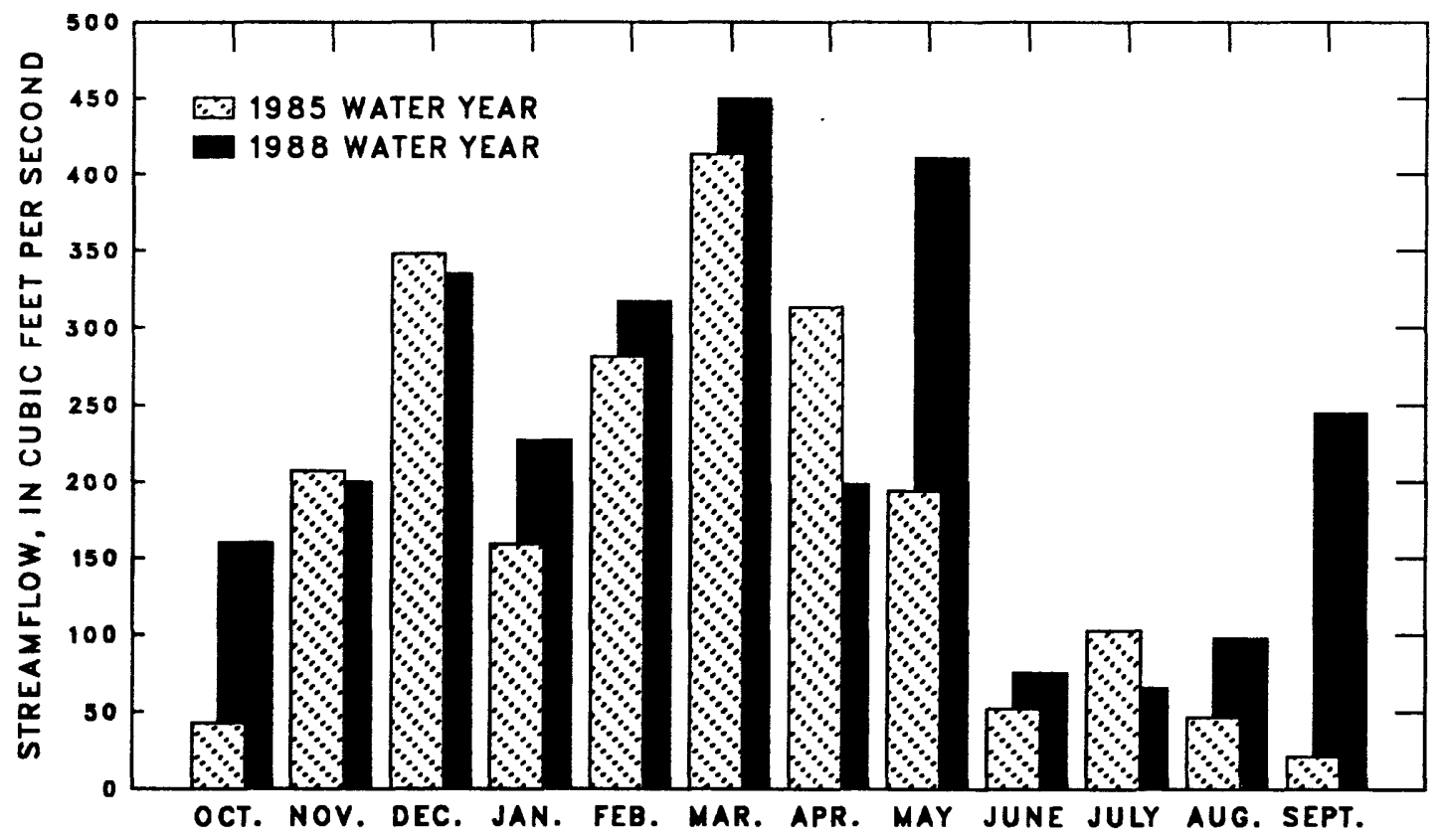

Figure 18.--Monthly stream flow for 1985 and 1988.

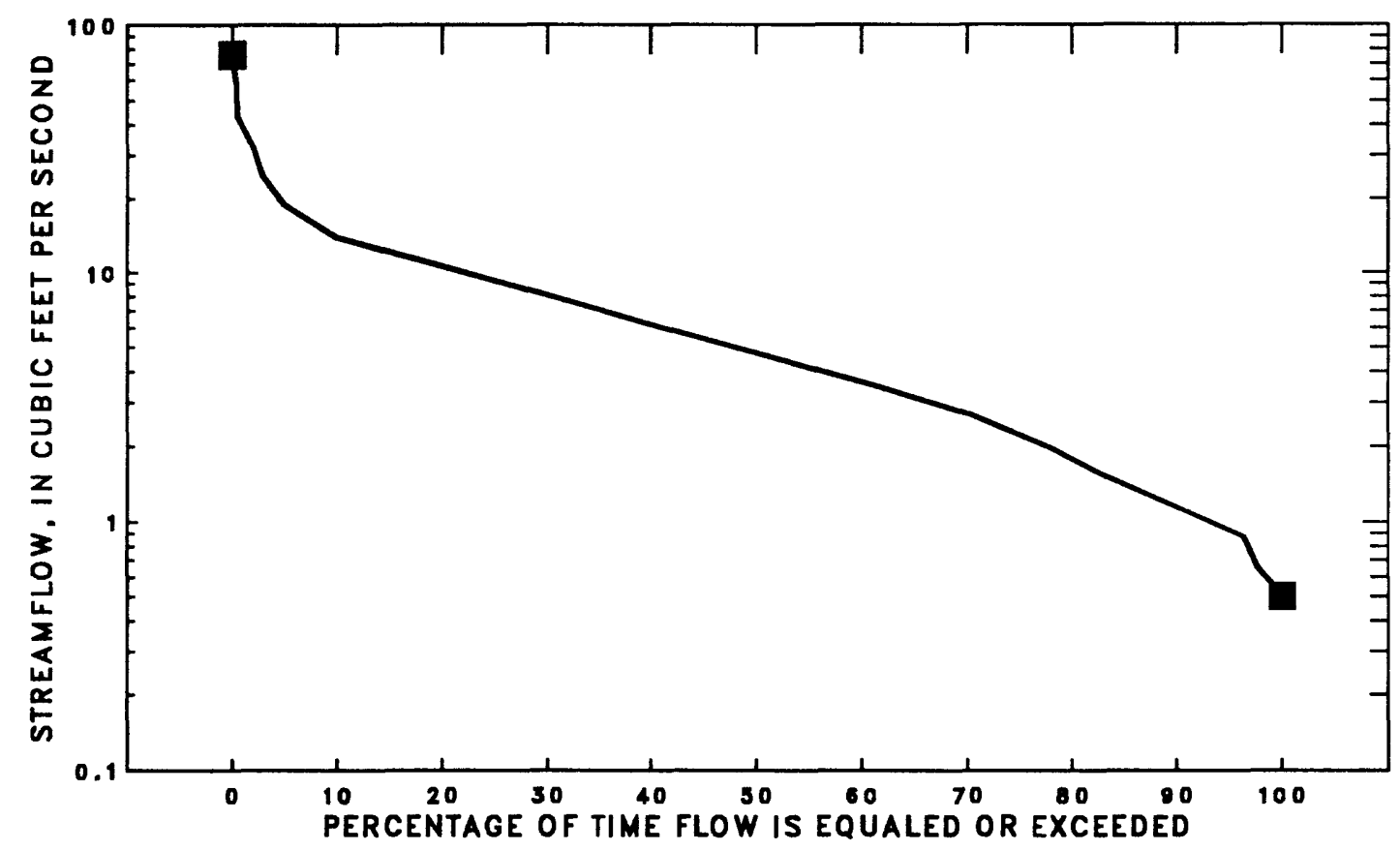

Figure 19.--Flow-duration curve for North Fork Bens Creek. 


\section{SUMMARY}

Basin and climatological characteristics, results of analysis for chemical-quality assurance, and hydrologic data for North Fork Bens Creek for the period August 1983 through September 1988 are summarized.

North Fork Bens Creek is on the eastern slope of Laurel Hill in northern Somerset County in southwestern Pennsylvania. Laurel Hill is anticlinal, consisting of sedimentary rocks of Mississippian and Pennsylvanian age. The exposed rock units consist of sandstone and shale. Soils are typically stony, silt-clays with good permeability, low shrink-swell potential, low erodability, and $\mathrm{pH}$ ranging from 3.6 to 5.5 .

Air temperature at the study basin is typically below freezing from November to March; January is the coldest month. Temperatures are typically highest in July and August; July is the warmest month. The longest recorded period of minimum daily temperatures below freezing was 171 days. The average number of days below freezing during the nongrowing season is typically 154 .

Snowfall data were not collected at the study site. However, snowfall data were collected during 1960-83 at the NOAA climatological station at Boswell, Pennsylvania. Snowfall averages about 69.5 inches annually.

Wind speed for Somerset County, as reported by the National Climatic Center (1985), averages 11 miles per hour in winter. Average solar radiation is computed from 23 years of record. Solar radiation typically is higher during the growing season from late April to early September, and the most intense period is from late May to early June.

Pan-evaporation data are available for southern Somerset County at Confluence, Pennsylvania. These data are representative of the region and are determined on a daily basis. Pan evaporation averages $0.17 \mathrm{in} /$ day during the growing season and 0.02 in/day during the nongrowing season. Pan evaporation consistently is highest during June and July.

Air quality for southwestern Pennsylvania is monitored annually by three state agencies. Four constituents monitored by these agencies are of specific importance to the environmental quality of the study area; these are sulfur dioxide, nitrogen dioxide, sulfate, and nitrate. Sulfur dioxide decreased in concentration in all western Pennsylvania "air basins", except Johnstown, from 1977 through 1986. Nitrogen dioxide remained constant during this period.

Sulfates, both primary and secondary, declined in concentration from 1977 through 1986. However, the 30-day sulfate standard has been exceeded throughout this 10-year period of record. Nitrate remained constant from 1977 through 1986. No air-quality standard for nitrate has yet (1989) been established.

Emission densities for sulfur oxides and nitric oxides are low in Somerset County. However, counties west of the study area have substantially higher densities, ranging from 1,000 to 450,000 tons per year. The prevailing west-southwest winds transport these emissions to the study area. 
Records of precipitation $\mathrm{pH}$ in 1955 and 1972 for the northeastern region of the United States show an increase in precipitation hydrogen ion concentration over the 17 years. Current data show that the $\mathrm{pH}$ of precipitation has continued a downward trend since the 1972 regional assessment. Average volume-weighted $\mathrm{pH}$ in the study basin currently is about 4.0.

Sulfuric and nitric acids in precipitation are the major components of precipitation acidity. Water-chemistry analyses of precipitation for the Laure1 Hill area show an abundance of sulfate, nitrate, and hydrogen ions, all of which are dissociation products of sulfuric and nitric acid.

The quality of the chemical data collected has been assured by a stringent quality-assurance program. Fifty-seven quality-assurance samples consisting of container blanks, filtration blanks, replicates, and spiked audit samples were submitted to the laboratory for analysis during the study. Field instruments were checked at least annually by the National Field Quality Assurance Program with satisfactory results. Laboratory and field analysis audit samples were supplied by the USEPA. Three of these spiked samples were analyzed in the field and the laboratory from October 1985 through September 1986. Results are assumed to be satisfactory based on USEPA correspondence. A "Working Protocol" was implemented in February 1985 by the USEPA, this document outlined the procedure for a stepped-up quality-assurance program. Twenty-seven of the 57 water-quality check samples were sent for analysis during this program. Strict adherence to the "Working Protocol" was discontinued in February 1986.

Observed precision of quality-assurance samples collected from August 1983 through February 1986 indicate that the relative standard deviations (RSD) of some constituents were greater than the precision goals outlined in the "Working Protocol". Container and filtration blanks for this period confirmed that the filtration apparatus were not contaminating the samples for most constituents.

Observed precision from March 1986 through September 1988 declined slightly compared to the previous period. Aluminum and base cations both exceeded the IRP goals for about 64 percent of the replicate samples. Replicate precision goals were considered marginal for this period. Container and filtration blank sample precision were both satisfactory.

Water-resources data collected by U.S. Geological Survey methods include surface-water quality, precipitation quantity, and streamflow.

Samples for water-quality analysis were collected monthly. Field parameters obtained at the time of sample collection included instantaneous streamflow, $\mathrm{pH}$, specific conductance, alkalinity, and acidity.

The concentrations of dissolved aluminum and the base cations varied less than those of other consituents. Alkalinity varied considerably, and negative alkalinities were observed during water years 1984, 1986, and 1988 . 
Precipitation data were continuously collected from October 1983 through September 1988. Precipitation during the study was 46, 3.7, and 1.2 percent above normal for water years 1984, 1985, and 1986, respectively. Annual precipitation was 41 and 4.4 percent below normal for 1987 and 1988, respectively.

Streamflow was continuously monitored for 2 water years, 1985 and 1988 . Daily-streamflow hydrographs for both data-collection periods show some seasonality of annual flow. About 70 percent of annual streamflow occurs during the nongrowing season. The maximum and minimum discharged for the combined 2-year period of record are $92 \mathrm{ft}^{3} / \mathrm{s}$ and $0.57 \mathrm{ft}^{3} / \mathrm{s}$, respectively. Annual maximum monthly streamflow occurs in March.

Increases in streamflow resulting from rainfall and snowmelt are "flashy". Near total return to base flow usually occurs within several hours after the end of a storm. 
Aquatic Effects Task Group, 1985, (revised 3/85). Working protocol for sampling, sample analysis, and QA/QC for the USEPA long-term surface water monitoring program: Draft of document, $20 \mathrm{p}$.

Barker, J.L., and Witt III, E.C., 1990, Effects of acid precipitation on the water quality of streams in the Laurel Hill area, Somerset County, Pennsylvania, 1983-86; Water Resources Investigation 89-4113, in press.

Berg, T.M. and others, 1981, Atlas of preliminary geologic quadrangle maps of Pennsylvania: Commonwealth of Pennsylvania, Department of Environmental Resources, Bureau of Topographic and Geologic Survey, map 61, 1 sheet, scale $1: 62,500$.

Bigelow, D.S., 1982, Draft NADP Instruction Manual/Site Operation, National Atmospheric Deposition Program, NC-141: Colorado State University, p. 30.

Bureau of Air Quality Control, 1987, Stationary source emission inventory report, 1986, Pennsylvania emission data system: Pennsylvania Department of Environmental Resources, Harrisburg, Pennsylvania, p. 1-55.

Craig, J.D., 1983, Installation and service manual for U.S. Geological Survey manometers: Techniques of Water Resources Investigations of the U.S. Geological Survey, book 8, chap. A2, p. 1-57.

Farnsworth, R.K., Thompson, E.S., and Peck, E.L., 1982, Evaporation atlas for the contiguous 48 United States: National Weather Service, Washington, D.C., National Oceanic and Atmospheric Administration Technical Report NWS $33,26 \mathrm{p}$.

Flint, N.K., 1981, Geology and mineral resources of southern Somerset County, Pennsylvania: Commonwealth of Pennsylvania, Department of Environmental Resources, Bureau of Topographic and Geologic Survey, County Report 56-A, p. $1-267$.

Friedman, L.C., and Erdmann, D.E., 1982, Quality assurance practices for the chemical and biological analyses of water and fluvial sediments: Techniques of Water Resources Investigations of the U.S. Geological Survey, book 5, chap. A6, $181 \mathrm{p}$.

Hickok IV, W.O. and Moyer, F.T., 1940, Geology and mineral resources of Fayette County, Pennsylvania, 530 p.

Hood, B.A., 1985, Report on the aquatic and terrestrial effects research review meeting of the National Acid Precipitation Assessment Program 13-16 November 1984, Asheville, North Carolina: North Carolina State University Acid Deposition Program, Raleigh, North Carolina, p. 1-63.

Hydrolab Corporation, 1982, An easily prepared low conductivity acid pH buffer, $4 \mathrm{p}$. 


\section{SELECTED REFERENCES - -Continued}

Kramer, J.R., 1980, Precise determination of low alkalinities using the modified Gran analysis, an inexpensive field procedure: McMaster University; Hamilton, Ontario, Environmental Geochemistry Report no. 1980/1, $15 \mathrm{p}$.

Likens, G.E., 1976, Acid precipitation: Chemical and Engineering News, v. 54, no. 48 , p. $29-37$.

Lohman, S.W., 1938, Ground water in south-central Pennsylvania: Pennsylvania Geologic Survey, 4th series, bull. W5, 315 p.

Lynch, J.A., Corbett, E.S., and Grimm, J.W., 1988, Atmospheric deposition: spatial and temporal variations in Pennsylvania--1987: Environmental Resources Research Institute, University Park, Pennsylvania, no. ER8806, p. 1-101.

McFayden, J.M., and Joyner, K.C., 1987, Report on the aquatic effects research meeting of the National Acid Precipitation Assessment Program 17-23 May 1987 New Orleans, Louisiana: North Carolina State University Atmospheric Impacts Research Program, Raleigh, North Carolina, p. 1-144.

National Acid Precipitation Assessment Program, 1985, Annual Report, 1985, $113 \mathrm{p}$.

1986-1988, NAPAP operating research plan: U.S. Government Printing Office, Washington, D.C., p. VI $80-$ VI 83.

National Climatic Center, 1981, Typical meteorological year user's manual TD9734: Asheville, North Carolina p. 1-30.

National Oceanic and Atmospheric Administration, 1960-1988, Climatologic Data Annual Summary: Asheville, North Carolina, National Climatic Data Center, Vols. $72-98$.

Pennsylvania Department of Environmental Resources, 1984 and 1986, Air quality report: Harrisburg, Pennsylvania, p. 1-81.

Rantz, S.E., 1982, Measurement and computation of streamflow, volume 1, Measurement of stage and discharge: U.S. Geological Survey Water-Supply Paper 2175, 284 p.

Searcy, J.K., 1959, Flow-duration curves--Manual of hydrology, part 2, lowflow techniques: U.S. Geological Survey Water-Supp1y Paper 1542-A, p. 1-33.

Sharpe, W.E., Leibfried, V.G., Kimme11, W.G., and DeWalle, D.R., 1987, The relationship of water quality and fish occurrence to soil and geology in an area of high hydrogen and sulfate ion deposition: Institute for Research on Land Water resources, v. 23, no. 1, p. 37-45. 


\section{SELECTED REFERENCES - - Continued}

Skougstad, M.W., Fishman, M.J., Friedman, L.C., Erdmann, D.E., and Duncan, S.S., eds., 1979, Methods for determination of inorganic substances in water and fluvial sediments: Techniques of Water-Resources Investigations of the U.S. Geological Survey, book 5, chap. Al, 626 p.

Taylor, J.K., 1988, Quality assurance of chemical measurements: Lewis Publishers, Inc., Chelsea, Michigan, 1 p.

U.S. Department of Agriculture, 1983, Soils Survey of Somerset County, Pennsylvania: Soil Conservation Service, $148 \mathrm{p}$.

Walling, D.E., and Foster, I.D.L., 1975, Variations in the natural chemical concentration of river water during flood flows, and the lag effect: Some further comments. Journal of Hydrology v. 26 p. 237-244. 